\title{
Arquitectura y soberanía: la catedral de Jaca y otras empresas constructivas de Sancho Ramírez
}

\author{
Javier MARTínez De AgUiRRe \\ Universidad Complutense de Madrid
}

El protagonismo del reinado de Alfonso VI (1072-1109) en el desarrollo del arte románico castellano-leonés, objeto de estudio de las jornadas cuyas actas aquí se publican, tiene su contrapunto en el papel que jugó su primo Sancho Ramírez (10641094) en la introducción del Románico Pleno en Aragón, reino que experimentó una definitiva consolidación durante su gobierno ${ }^{1}$. Sancho y Alfonso pertenecían a dos ramas de un mismo linaje, el de los descendientes de Sancho III el Mayor de Pamplona (1004-1035), de quien eran nietos: Alfonso al ser segundogénito de Fernando I y Sancha de León, y Sancho como primogénito de Ramiro I, hijo extramatrimonial de Sancho III y Sancha de Aibar (véase cuadro genealógico, fig. 1). Sin embargo, los respectivos reinos y sus tradiciones constructivas, así como el origen y naturaleza del poder que ejercían eran notablemente distintos. Alfonso alcanzó, tras complejas y cruentas vicisitudes, un trono consolidado, el leonés, donde el mecenazgo arquitectónico regio contaba con tradición secular anclada en el antecedente asturiano. Sancho Ramírez, en cambio, rigió inicialmente un territorio pequeño, resultado de la adición de antiguos condados, donde apenas pueden documentarse empresas arquitectónicas religiosas relevantes financiadas por sus dirigentes, mientras que las edificaciones militares habían alcanzado un notable desarrollo. A partir de 1076 gobernó también un espacio mayor y más reconocido, el reino de Pamplona, cuyos reyes habían auspiciado recientemente obras eclesiásticas de cierta ambición como el monasterio de Leire, San Millán de la Cogolla o Santa María de Nájera. Con todo, la promoción artística de los monarcas pirenaicos durante los siglos X y XI no hacía presagiar la brillante eclosión de edificios relacionados con la familia regia emprendidos en Aragón en las últimas décadas del siglo XI y primeras del XII².

1 Esta investigación se ha realizado en el marco del proyecto "Arte y monarquía en el nacimiento y consolidación del reino de Aragón (1035-1134)", HAR2009-08110, financiado por el Ministerio de Ciencia e Innovación.

2 Desde los primeros estudios sistemáticos sobre románico hispano se ha advertido su relevancia. Véanse, por ejemplo, las opiniones de W.M. Whitehill, Spanish Romanesque Architecture of the Eleventh Century, Oxford, 1941, con respecto a uno de los empeños más directamente dependientes del monarca, la iglesia del castillo de Loarre: "una de las iglesias más sofisticadas del Románico español y uno de sus tres grandes logros, junto con Santiago y Silos" (pp. 244 y 249); en la misma línea, las alabanzas sobre su escultura de A.K. PORTER, "Iguácel and more Romanesque Art of Aragón", The Burlington Magazine, LII (1928), p. 128. 


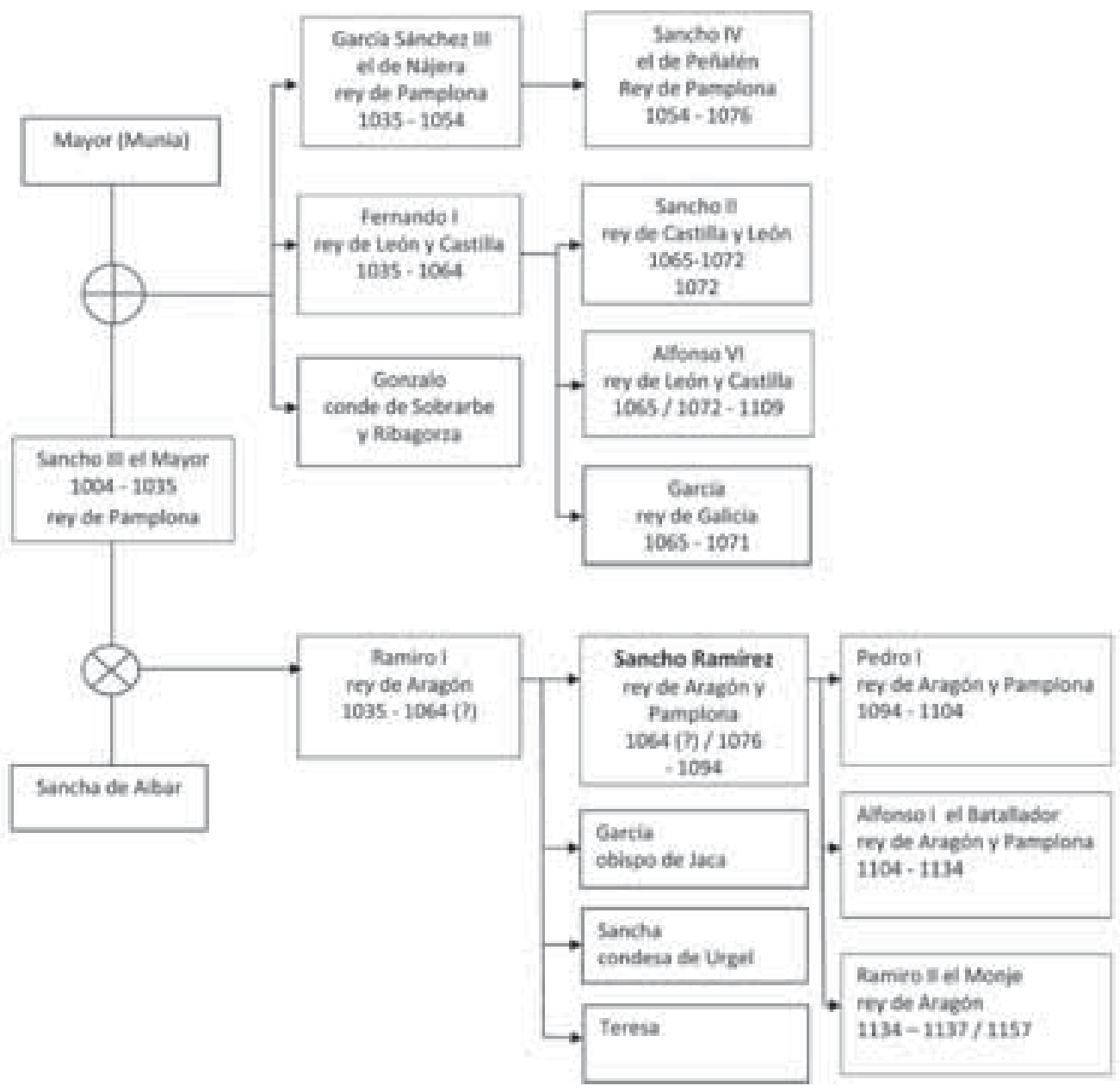

Fig. 1. Cuadro genealógico

La intención de esta ponencia consiste en proyectar una nueva mirada sobre ciertas empresas constructivas relacionadas con Sancho Ramírez a la luz de las circunstancias históricas en que se gestaron ${ }^{3}$. Advertiremos el cambio de escala en dimensiones, calidad y significados con respecto a las ejecutadas por su padre y antepasados, cambio que, por una parte, fue solidario con los nuevos retos asumidos por la arquitectura re-

3 El cambio que significaron los encargos arquitectónicos de Sancho Ramírez ha sido explorado por distintos autores. La aportación más reciente, indudablemente valiosa, corresponde a J. MANN, Romanesque Architecture and Its Sculptural Decoration in Christian Spain, 1000-1120, Toronto, Buffalo, Londres, 2009, pp. 101-131 (en adelante: MANN, Romanesque). La ponencia que aquí presento pone el acento en circunstancias históricas y desarrolla análisis artísticos que inciden en la misma idea con una orientación propia y con conclusiones personales en lo relativo a algunas de las empresas constructivas más significativas. 
ligiosa a nivel europeo en los comienzos del Románico Pleno y, por otra, evidencia un paralelismo con otras facetas en las que el comportamiento del soberano sobrepasó con mucho lo ejercido por su progenitor. Son estos encargos novedosos los que hicieron de Sancho Ramírez una figura imprescindible para comprender la introducción y desarrollo de este segundo arte románico en la Península Ibérica. Y exploraremos ciertas peculiaridades de su comportamiento, con la intención de aquilatar la trascendencia de acontecimientos históricos entre los que merecen ser destacados su viaje a Roma de 1068 y su acceso al trono pamplonés tras el asesinato de Sancho IV en 1076.

\section{Antecedentes I: la arquitectura aragonesa antes de Sancho Ramírez}

A la hora de calibrar la novedad que supuso la aportación arquitectónica de Sancho Ramírez, hemos de ponerla en parangón con dos tradiciones: por una parte, la participación de los gobernantes en los principales encargos constructivos aragoneses previos a 1064, con especial atención a Ramiro I; por otra, las empresas arquitectónicas de la monarquía pamplonesa, a cuyo trono accedió en 1076.

Las construcciones de ámbito aragonés anteriores a 1035 arraigan en fórmulas hispánicas, que se van enriqueciendo con aportaciones de territorios vecinos y de procedencia más lejana ${ }^{4}$. Entre las edificaciones llegadas total o parcialmente a nuestros días existen, en primer lugar, iglesitas caracterizadas por su limitadísima relevancia y ambición que, a partir de restos poco elocuentes, fueron fechadas por Galtier en el entorno del año mil. Aunque en ocasiones aparecen próximas a fortificaciones de primer nivel (Sos, Luesia, Murillo de Gállego), ninguna acusa la intervención de dirigentes deseosos de manifestar ostentosamente su piedad y magnificencia a través de las dimensiones y el esplendor constructivo (serían, en el mejor de los casos, simples capillas castrales) ${ }^{5}$.

4 Como obra de conjunto referida a lo que se va a tratar en este epígrafe: J.F. Esteban LoREnTE, F. Galtier Martí y M. García Guatas, El nacimiento del arte románico en Aragón. Arquitectura, Zaragoza, 1982 (en adelante citado: Esteban, Galtier y García, Nacimiento). Hallazgos arqueológicos de los últimos treinta años y nuevas aportaciones de estos autores y de Bernabé Cabañero han completado sus presupuestos sobre el panorama arquitectónico prerrománico y románico inicial en Aragón. El planteamiento de A. DuRÁN Gudiol, Arte altoaragonés de los siglos Xy XI, Sabiñánigo, 1973 (resumen en ID., "Arquitectura Altoaragonesa. Siglos VIII-XI”, Signos. Arte y Cultura en el Alto Aragón Medieval, Jaca-Huesca, 1993, pp. 87-93), que veía en Siresa el exponente del Renacimiento Carolingio y en las iglesitas de cabecera recta un eco de tradiciones visigóticas "posiblemente debidas a inmigraciones navarras", se ha visto desmentido en cuanto a Siresa por la arqueología.

5 F. Galtier Martí, "Las primeras iglesias de piedra de la frontera de los Arbas, el Onsella y el Gállego", Artigrama, 1 (1984), pp. 11-46; ID., "Las grandes líneas del arte prerrománico aragonés”, Artigrama, 8-9 (19911992), pp. 259-279; ID., "Les conditions et les développements de l'art préroman et les débuts de l'art roman dans les comtés de Ribagorza et d'Aragon", Les Cahiers de Saint-Michel de Cuxa, XXIII (1992), pp. 55-63 (cfr. Simposi internacional d'arquitectura a Catalunya. Girona 1988. Segles IX, X i primera meitat de l'XI, Gerona, 1994, pp. 77-103); ID. 'L'aurore de l'art roman dans le royaume d'Aragon", Butlletí del Museu Nacional d'Art de 
El estado inmediatamente previo a la introducción de soluciones característicamente románicas se plasma en el monasteriolo de San Julián de Asprilla (Santa Isabel de Espuéndolas), de nave única, cabecera recta más estrecha que la nave y puerta en arco de herradura ${ }^{6}$. Esta modesta iglesita habría sido edificada probablemente por iniciativa del noble Sancho Garcés, poco antes de su donación a San Juan de la Peña en 1049. Por tipología y dimensiones (nave de 9 x 4,30 m y cabecera de $3,10 \times 3,30 \mathrm{~m}$ ) pertenece a la misma categoría el edificio religioso del Corral de Calvo, en el término municipal de Luesia, donde un arco de medio punto de buena sillería separa cabecera y nave. Ha podido ser datado hacia 1027 $( \pm 20)$ gracias al análisis del carbón vegetal mezclado con la cal en los muros de la cabecera ${ }^{7}$. Junto al templo existieron dependencias que no aclararon la entidad del hábitat (¿monasteriolo, villa, palatium?). Si bien no existe documentación que relacione estos vestigios con la familia regia, es preciso hacer mención de que en la Peña de las Eras de Luesia fue localizado en 1977 un relieve un tanto tosco en el que un personaje coronado, de anatomía desproporcionada, sostiene con su mano derecha una cruz procesional. La figura fue interpretada por Galtier como "la imagen del rey cristiano y debelador de los enemigos de Cristo", realizada hacia $975^{8}$. Los nexos de la localidad con la familia regia, debido a su ubicación fronteriza, han sido señalados por el mismo autor.

Los templos que según diplomas -en ocasiones problemáticos- fueron fundados por los condes de Aragón apenas conservan vestigios materiales. Es el caso de San Martín de Cercito, promovido por Galindo II a comienzos del siglo X en el valle de Acumuer'. Por medio de conjeturas, Durán atribuyó al mismo conde la fundación de San Pedro el Viejo de Jaca "como jalón de la conquista y repoblación del Campo de Jaca", posteriormente restaurado por Ramiro I ${ }^{10}$. Excavaciones em-

Catalunya, I, 1 (1993), pp. 37-55 (versión castellana con modificaciones en "La formación del arte románico aragonés, entre la reconquista y la repoblación", Actas del III Curso de Cultura Medieval. Seminario: repoblación y reconquista, Aguilar de Campoo, 1993, pp. 127-134). A comienzos del siglo XI también cabe situar San Aventín de Bonansa y San Pablo de Tella (consagrada en 1019), con ábsides de herradura, fórmula con evidentes paralelismos en la tradición hispana. Para B. CABAÑERO SuBIZA, "Precedentes musulmanes y primer arte cristiano", Las Cinco Villas aragonesas en la Europa de los siglos XII y XIII: de la frontera natural a las fronteras políticas y socioeconómicas (foralidad y municipalidad), Zaragoza, 2007, pp. 226-227 (en adelante citado: CABAÑERO, "Precedentes"), estaríamos ante una "primera oleada renovadora" favorecida por la construcción de torres militares cilíndricas que experimentaron antes en Cataluña que en Aragón.

6 F. Galtier Martí, "En torno a los orígenes del círculo larredense: San Julián de Asperella", Artigrama, 4 (1987), pp. 11-24.

7 F. Galtier Martí y J.A. Paz Peralta, Arqueología y arte en Luesia en torno al año mil. El yacimiento de "El Corral de Calvo", Zaragoza, 1987.

8 B. Cabañero Subiza y F. Galtier Martí, "Tuis exercitibus crux Christi semper adsistat. El relieve real prerrománico de Luesia”, Artigrama, 3 (1986), pp. 11-28. Invocan paralelos en la miniatura riojana de la segunda mitad del siglo X y en los relieves de Villatuerta dedicados al ordo visigótico de salida del rey en campaña contra sus enemigos. El entrecomillado en F. GALTiER, "Relieve real de Luesia", Sancho el Mayor y sus herederos. El linaje que europeizó los reinos hispanos, Pamplona, 2006, vol. I, pp. 79-80.

9 A. Ubieto Arteta, Cartulario de San Juan de la Peña, I, Valencia, 1962, docs. 5, 9, 10 y 11, pp. 26-42.

10 A. Durán Gudiol, El monasterio de San Pedro de Siresa, Zaragoza, 1989, p. 25. 
prendidas en 2001 sacaron a la luz las cimentaciones de este edificio situado ante el pórtico occidental de la catedral, que comparte tipología con Corral de Calvo y Asprilla (nave única y cabecera recta estrecha) ${ }^{11}$. Aparece mencionado en documentos de las décadas centrales del siglo $\mathrm{XI}^{12}$.

San Juan de la Peña ha mantenido estructuras de reducido tamaño y notable interés. La llamada iglesia baja, constituida por dos naves y cabecera doble en la que emplearon aparejo irregular y arcos de herradura, tradicionalmente venía siendo fechada en el siglo IX; estudios más recientes la ubican en el $\mathrm{X}^{13}$. De tres naves y cabecera única de remate recto fue el templo de San Pedro de Siresa previo al actual, cuyos cimientos conocemos gracias a las excavaciones de $1991^{14}$. De modo muy parcial conservamos vestigios de una iglesia anterior en Santa María de Santa Cruz de la Serós, erigida posiblemente entrado el siglo XI, con cabecera recta y dimensiones probablemente pequeñas ${ }^{15}$.

Para terminar este breve panorama de la arquitectura religiosa previa a Ramiro I es preciso mencionar la problemática de las iglesias del Primer Románico Meridional, algunas de las cuales han sido relacionadas con reyes o condes. La interpretación de los elementos arquitectónicos y de los indicios documentales llevó a Esteban, Galtier y García Guatas a situarlas en las primeras décadas del siglo XI y a considerarlas obra de maestros lombardos ${ }^{16}$. Sus maneras de construir por medio

11 J. Justes Floría y B. Gimeno Martínez, "Estudio antropológico y paleopatológico de los restos humanos exhumados en la excavación de la iglesia de San Pedro el Viejo (Jaca)", Saldvie, 3 (2003), pp. $243-255$. La contextualización del hallazgo en: CABAÑERO, "Precedentes", p. 223.

12 In Iaca vero monasterium nomine Sancti Petri cum suas hereditates: A. Durán Gudiol, Colección Diplomática de la Catedral de Huesca, Zaragoza, 1965, doc. 17, p. 33; ID., El monasterio de San Pedro de Siresa, Zaragoza, 1989, p. 25. Los hallazgos arqueológicos, concretamente la nave única, han venido a desmentir una hipótesis de Durán, según la cual el famoso "documento del mercado" (de él hablaremos más adelante), que describe la voluntad de abovedar las tres naves de la catedral jaquesa, se referiría a San Pedro el Viejo (ibídem, p. 26).

13 Gómez Moreno supuso que "el edificio primitivo actual ya existía en 924 y databa verosímilmente de hacia 850”: M. Gómez Moreno, Iglesias mozárabes. Arte español de los siglos IX a XI, Madrid, 1919 , p. 40. Comparten la cronología del siglo IX buen número de autores posteriores, entre ellos A. CANELLAS LóPEZ y A. San Vicente, Aragon Roman, La Pierre-qui-Vire, 1971, p 74 (en adelante citado: Canellas y San Vicente, Aragon). Actualmente se considera obra de la segunda mitad del siglo X: F. Galtier Martí, "Las grandes líneas del arte prerrománico aragonés”, Artigrama, 8-9 (1991-1992), pp. 269-270.

14 R. Puertas Tricas, "Planteamiento general de las excavaciones de San Pedro de Siresa", Arqueología Aragonesa 1991, Zaragoza, 1994, pp. 171-179; ID., Excavación en San Pedro de Siresa, Huesca, 1993; no concluye una única hipótesis acerca de su cronología, aunque los materiales comparativos que aporta inducen a pensar que la considera prerrománica. De nave única pero con tres capillas de remate recto es San Bartolomé de Bergua, publicada por A. CASTÁn SARASA, Románico e iglesias de cabecera triple en la Ribera del Ara $y$ Valle de Vió, Huesca, 1990. Cabañero (cfr. nota 5) la considera fruto de una "segunda oleada renovadora" hacia 1040-1050 procedente del arco alpino.

15 J.A. Paz Peralta, F. Galtier Martí y M.E. Ortiz Palomar, "Iglesia del Monasterio de Santa Cruz de la Serós (Huesca): Aportaciones arqueológicas a su arquitectura”, Arqueología Aragonesa 1991, Zaragoza, 1994, pp. 191-195.

16 Esteban, Galtier y García, Nacimiento, pp. 124-148. No comparte su visión acerca de la arquitectura del primer románico Philippe Araguas (véase nota 32). Al respecto, son de interés las reflexiones de Durliat relativas al limitado papel de los antecedentes italianos en la arquitectura del Primer Románico catalán: M. Durliat, "La Catalogne et le « Premier Art Roman »”, Bulletin Monumental, 147 (1989), pp. 209-238. 
de sillarejos de cierta uniformidad en paramentos ya sea lisos, ya sea articulados mediante lesenas y arquillos, habrían sido emuladas por canteros locales en edificaciones que dichos historiadores bautizaron como "lombardistas". Ubican la labor de los lombardos en las primeras décadas del siglo XI; la de sus seguidores se prolongaría durante el resto de la centuria y aún después.

La intervención de la familia de Sancho el Mayor en la iglesia de San Caprasio ha sido defendida por su pertenencia a Sancho Ramírez cuando éste la donó a San Juan de la Peña en $1086^{17}$. Se trata de una obra de tamaño modesto, proporciones cuidadas y ejecución en una única campaña "con muy poco cuidado", que según Esteban Lorente pudo haberse ejecutado por "una cuadrilla de tres o cuatro personas" 18 . No todos los autores coinciden en suponerla de tiempos de Sancho el Mayor, puesto que ya Íñiguez, Sánchez Ventura, y Whitehill la situaron a finales del siglo XI, lo que resulta hoy difícilmente sostenible; Durán Gudiol defendió su realización durante el reinado de Ramiro $\mathrm{I}^{19}$. La documentación vuelve a ser desesperadamente escueta y discutible. Santa María de Obarra, mucho más ambiciosa, quedó interrumpida y hubo de ser concluida por canteros locales. La tradición historiográfica había atribuido su fundación al conde Bernat de Ribagorza, hasta que Ramón D'Abadal demostró la inconsistencia de la afirmación ${ }^{20}$. Su construcción podría corresponder al abadiato de Galindo, en las primeras décadas del siglo XI, cuando el cenobio vivió "una etapa de brillante renovación y de marcado dinamismo expansivo" seguida por un período de "anquilosamiento y decadencia" (Martín Duque) tras la muerte de dicho abad entre 1025 y 1035, que podría explicar la interrupción de la fábrica y su terminación más tardía ${ }^{21}$. Los primeros años de la

17 J. Salarrullana y de Dios, Colección de documentos para el estudio de la historia de Aragón. T. III. Documentos correspondientes al reinado de Sancho Ramírez. Vol. I Desde 1063 hasta 1094 años. Documentos reales procedentes de la Real Casa y Monasterio de San Juan de la Peña, Zaragoza, 1907, doc. XXIX, pp. 91-93 (en adelante citado: Salarrullana, Documentos). F. Galtier Marti, "L'église San Caprasio à Santa Cruz de la Serós (Aragón): une microstructure lombarde", Immagine e Ideologia. Studi in onore di Arturo Carlo Quintavalle, Parma-Milán, 2007, pp. 88-95; ID., "Aragón en la época del beato de Fanlo", El beato del abad Banzo del monasterio de San Andrés de Fanlo, un Apocalipsis aragonés recuperado. Facsímil y estudios, Zaragoza, 2005, p. 205. Ha sido identificada sin fundamento seguro con el topónimo San Cipriano citado en documentos de Ramiro I de 1059, 1061 y 1064 (Esteban, Galtier y García, Nacimiento, p. 128); el último diploma indica que el rey había realizado trabajos en baños y palacios (et quare me indereças meas labores bene in Sancti Cipriani de meos banios et palatios): R. Viruete ERdozáin, Aragón en la época de Ramiro I, tesis doctoral: www.tesisenred.net, docs. 130, 145 y 196, no identifica la ubicación del topónimo con exactitud (en adelante citado: Viruete, Aragón).

18 J.F. Esteban Lorente, "La metrología y sus consecuencias en los edificios de la Alta Edad Media Española. III: El Primer Románico en España", Artigrama, 22 (2007), pp. 433-437. Galtier la estima "monumento puro y refinado, muestra excelente de la maestría de los arquitectos lombardos" (cfr. nota anterior).

19 A. Durán Gudiol, "Arquitectura Altoaragonesa. Siglos VIII-XI", Signos. Arte y Cultura en el Alto Aragón Medieval, Jaca-Huesca, 1993, p. 92.

20 Ramon d’Abadal i de Vinyals, Catalunya Carolíngia. Volum III. Els comtats de Pallars i Ribagorça, Barcelona, 1955, II, pp. 266-270.

21 A. J. Martín DuQue, Colección Diplomática de Obarra (Siglos XI-XIII), Zaragoza, 1965, pp. XXI-XXII; F. GaLtier MarTí, Ribagorza, condado independiente. Desde los orígenes hasta 1025, Zaragoza, 1981, p. 189. 
centuria supusieron un momento crítico para el poder político del condado, que desembocó en su dominación por Sancho el Mayor, quien acabaría confiándolo a su hijo Gonzalo. No es posible verificar una responsabilidad directa de los condes, Sancho III o Gonzalo en la edificación del gran templo.

El impacto de las nuevas maneras de construir románicas afectó de diverso modo a la práctica arquitectónica en tierras aragonesas. Una respuesta de notable interés generó el grupo de iglesias comúnmente denominado "larredense" o de Serrablo, de cronología debatida ${ }^{22}$. Sus descubridores, Íñiguez y Sánchez Ventura, se preguntaron si corresponderían a "unas de las muchas iglesias" levantadas por orden de Ramiro ${ }^{23}$. No puede sostenerse que toda iglesia donada por los reyes a instituciones religiosas (y en particular estas modestas construcciones rurales) responda a la directa intervención de los monarcas. En 1971 el propio Íñiguez y Uranga revisaban su cronología a partir de citas en la documentación del siglo X, concluyendo que el grupo integrado por Lárrede y otras ocho podía confirmarse "en los finales del X (...) aunque alguna vaya por los primeros años del XI, pues los siglos no tienen fronteras", con lo que lo alejaban del mecenazgo regio ${ }^{24}$. Durán Gudiol les siguió en el radical adelanto de la cronología ${ }^{25}$. Esteban, Galtier y García las vincularon con la afirmación del "poder público cívico-religioso" canalizado por los monasterios de Fanlo y Basarán y los señores locales a mediados de la undécima centuria ${ }^{26}$. Sus peculiares soluciones de vanos y ornamentación paramental perduraron en el ámbito comarcal.

En cuanto a la arquitectura civil previa a Ramiro I, la defensa del territorio había propiciado la edificación de castillos en los pasos naturales de las comarcas

22 F. Í̃̃IgueZ y R. SÁnchez Ventura, "Un grupo de iglesias del Alto Aragón”, Archivo Español de Arte y Arqueología, $\mathrm{n}^{\circ}$ 27, IX (1933), p. 235, "parecen adentrarse bastante los tipos primeros de la serie en el siglo XI" y adscriben a lo mozárabe ciertos elementos. M. Gómez Moreno, El arte románico español. Esquema de un libro, Madrid, 1934, pp. 51-52 (en adelante citado Gómez MoRENo, El arte románico) de manera paradójica las describe inicialmente como "obra de andaluces, impregnada de arabismos" sin "ninguna contaminación lombarda ni jaquesa", aunque más adelante añade que "sus ábsides y arquerías ciegas pueden traer origen de Lombardía". R. Del Arco y Garay, Catálogo Monumental de España. Huesca, Madrid, 1942, I, p. 366, sitúa Lárrede a finales del siglo XI. Varios autores más se han ocupado de los nexos "mozárabes" o musulmanes, incluso se han planteado las dificultades de introducir determinadas obras rurales en clasificaciones estilísticas: R. CRozet, "Petites églises de la vallée du Gallego (Espagne)", Cahiers de Civilisation Médiévale Xe-XII Siècle, XII (1969), pp. 287-290.

23 F. Í̃̃IgueZ y R. SÁnchez Ventura, "Un grupo de iglesias del Alto Aragón”, Archivo Español de Arte y Arqueología, no 27, IX (1933), p. 235.

24 Aunque quizá insinúan la intervención de un poder centralizado cuando las enjuician "construidas de una vez, a lo largo de la vía entre Huesca y Sallent"; es más, afirman que su peculiar arquitectura murió "ahogada por el románico traído por Ramiro I a Roda de Isábena primero y luego a Jaca": J.E. URANGA y F. Í ÑIGUEZ Almech, Arte medieval navarro. Volumen Primero. Arte prerrománico, Pamplona, 1971, pp. 119-126 (en adelante citado: Uranga e ÍñIGUEZ, Arte medieval).

25 Ubica la ejecución del primer grupo entre 950 y 1000 "como fruto de la ocupación de Serrablo por el ejército navarro-aragonés": A. DuRÁn Gudiol, Arte altoaragonés de los siglos Xy XI, Sabiñánigo, 1973, p. 57; ID., El monasterio de San Pedro de Siresa, Zaragoza, 1989, passim.

26 Esteban, Galtier y García, Nacimiento, pp. 213-214; en pp. 208-212 hacen derivar el grupo del Primer Románico Meridional combinado con formas tomadas de la miniatura prerrománica hispana. 
fronterizas y en otros emplazamientos que facilitaban el control del territorio ${ }^{27}$. Los puntos fuertes de la frontera sur organizada por Sancho Garcés I (905-925) habrían estado dotados de defensas, en un principio preferentemente de madera, erigidas en lugares favorables por sus condiciones orográficas y su interés estratégico. Galtier afirma que más tarde habrían sido reedificadas en piedra (vestigios de estas campañas serían rastreables en Sos, Luesia y Biel) ${ }^{28}$. Durante la primera mitad del siglo XI se produjo un cambio de notables consecuencias. Todavía en la primera década el territorio aragonés estuvo a merced de los ataques cordobeses. La caída del califato (1010) y el fortalecimiento del poder cristiano habrían generado una reorganización de la línea defensiva. Una problemática bula papal atribuye a Sancho III la edificación de Ruesta, Ull, Sos, Uncastillo, Luesia, Biel, Agüero y Murillo; y la Crónica de Alaón renovada le asigna la construcción de castillos en Ribagorza; en caso de que las informaciones sean verosímiles (hay divergencias al respecto), de ellas se desprendería, sobre todo, la importancia de la red de castillos, probablemente más valiosa por sí misma que por la relevancia de una determinada construcción $^{29}$. En 1973 Philippe Araguas analizaba un grupo de castillos situados en la frontera y relacionaba directamente Loarre y Abizanda con el primer románico catalán, proporcionando una datación hacia 1040-105030. En la obra de 1982 que ya hemos citado, Esteban, García Guatas y Galtier propusieron adelantar las fechas de creaciones señeras como Fantova y Abizanda, que suponían obra de maestros lombardos: la primera sería una derivación mejorada de la catalana de Vallferosa

27 B. Cabañero Subiza y F. Galtier Martí, "Los primeros castillos de la frontera de los Arbas y el Onse1la. Problemas metodológicos", Boletín del Museo e Instituto Camón Aznar, XX (1985), pp. 59-85; F. GALTIER MARTí, "Les châteaux de la frontière aragonaise entre le préroman et l'art roman. Lignes de recherche", Les Cahiers de Saint-Michel de Cuxa, 17 (1986), pp. 197-235.

28 Además de las referencias de la nota anterior: F. GALTIER MARTí, "Las grandes líneas del arte prerrománico aragonés", Artigrama, 8-9 (1991-1992), pp. 266-268.

${ }_{29}$ Quae edificata ab auo tuo Santio rege fuere: P. KeHR, "Cómo y cuándo se hizo Aragón feudatario de la Santa Sede", Estudios de Edad Media en la Corona de Aragón. Sección de Zaragoza, vol. I, Zaragoza, 1945, pp. 314-317 (en adelante citado: KeHr, “Cómo y cuándo”). Sobre el pasaje de la Crónica de Alaón: F. Galtier Martí, Ribagorza, condado independiente, Zaragoza, 1981, p. 231. R. Viruete ErdozÁIN, "Los castillos aragoneses del primer románico: "ad examplamentum christianorum et malum de mauros", Actas del III Congreso de Castellología Ibérica, Guadalajara, 2005, p. 204, ha contrastado la noticia con documentos de la época para concluir que Sancho III sólo promovió en Ribagorza los castillos de Lascuarre, Benabarre y Cacabiello (en adelante citado VIRUETE, "Castillos"). En los últimos años se ha destacado la aparición en la Península hacia el año mil de castillos organizados en redes: Ph. ArAguAs, "Le château dans l'Espagne chrétienne autour de l'an mil', Guerre, pouvoir et idéologies dans l'Espagne chrétienne aux alentours de l'an mil, Turnhout, 2005, pp. 70-71. Sobre la relación con el poblamiento: Ph. SÉNAC, "Châteaux et peuplement en Aragon du VIII ${ }^{\mathrm{e}}$ au XI $\mathrm{I}^{\mathrm{e}}$ siècle”, “L'Incastellamento”. Actas de las reuniones de Girona (26-27 noviembre 1992) $y$ de Roma (5-7 mayo 1994), Roma, 1998, pp. 123-141. Es interesante la llamada de atención de C. LALIENA, La formación del estado feudal. Aragón y Navarra en la época de Pedro I, Huesca, 1996, p. 41 relativa al hecho de que las fuentes generalmente hablan de las honores, no de la materialidad de las construcciones que suponemos ligadas a ellas (en adelante citado: LaLiena, Formación).

$30 \mathrm{Ph}$. Araguas, "Les châteaux de la frontière Aragonaise au XI' siècle", L'Information d'Histoire de l'Art, XVIII-5 (1973), pp. 199-203. 
y en ella habría "reinado" el conde Guillermo Isárnez ${ }^{31}$; la segunda habría sido el centro de poder de Gonzalo, hijo de Sancho III y hermanastro de Ramiro I. No comparte Araguas ni esta datación ni el protagonismo de los lombardos, argumentando que: a) construcciones tan monumentales y cuidadas como Abizanda no podrían haberse alzado en un período de poder musulmán bien asentado, por lo que deberían ser posteriores a 1044; b) la conexión entre personajes de hipotético origen lombardo y la construcción de castillos descansa sobre relaciones circunstanciales y referencias documentales interpretables; y c) sería más apropiado hablar también para los castillos de Primer Románico Meridional, locución que no privilegia la intervención de maestros lombardos como mecanismo de transmisión de soluciones arquitectónicas y restablece el protagonismo del arte catalán en ese interesantísimo período creativo ${ }^{32}$.

El recinto superior del castillo de Loarre constituye obra culminante de la castellología previa al Románico Pleno. Aunque ya Ricardo del Arco diferenciaba en 1917 sucesivas etapas constructivas, todavía no tenía conciencia de que la parte superior del castillo pertenecía al período inicial, puesto que databa la torre del Homenaje en "la transición del siglo XII-XIII" dios, fue factible un análisis más apurado de la arquitectura ${ }^{34}$. En 1943 Chamoso Lamas veía en la Torre de la Reina "retazos de mozarabismo, es decir, muestras

31 F. Galtier Martí, Ribagorza, condado independiente. Desde los orígenes hasta 1025, Zaragoza, 1981, pp. 168-178; ID., "Les châteaux lombards de l'Aragon, à l'aube de la castellologie romane occidentale. La tour ronde", Les Cahiers de Saint-Michel de Cuxa, 18 (1987), pp. 173-206. Previamente sobre Abizanda: M. García GuAtas, "El castillo de Abizanda, en la frontera de la reconquista aragonesa", Homenaje a don José María Lacarra de Miguel en su jubilación del profesorado. Estudios medievales, I, Zaragoza, 1977, pp. 122133, la considera derivada de Loarre y ejecutada "a comienzos de la segunda mitad del siglo XI, siguiendo la política defensiva de Ramiro I"; J.F. Esteban LoREnTE y M. GARcía GuATAS, "Fortificaciones cristianas y organización fronteriza en el siglo XI", Primer Coloquio de Arte Aragonés, Teruel, 1978, pp. 95-125, estiman Abizanda obra de probable patrocinio real (Fantova sería monástica) y la relacionan de manera genérica con castillos franceses. Más recientemente: B. CABAÑERo SubizA, "La transición del prerrománico al románico en la castellología aragonesa y catalana”, Les Cahiers de Saint-Michel de Cuxa, XXIII (1992), pp. 65-81.

$32 \mathrm{Ph}$. Araguas, "Le château de Loarre et les châteaux de la frontière aragonaise au XI' siècle: leur place dans l'architecture militaire de l'Occident chrétien", La marche supérieure d'Al Andalus et l'Occident chrétien, Madrid, 1991, p. 172 (en adelante citado Araguas, "Loarre"; ID., "Mozarabes et lombards: les châteaux du premier art roman en Aragon et Catalogne", Actas del I Congreso de Castellología Ibérica. 1994, Palencia, 1998, pp. 15-31;

${ }^{33}$ Atribuía la cripta, la escalera y el cuerpo de guardia a Ramiro I, debido a una incorrecta lectura de la inscripción de Tulgas incisa en la jamba de la puerta de acceso a la escalera monumental; según su opinión, Sancho Ramírez habría continuado los trabajos en la mayor parte de la iglesia, terminados por Pedro I: R. DEL ArCo, El castillo real de Loarre, Madrid, 1917, pp. 75-78. La inscripción con la fecha de 1095 había sido correctamente leída por el Padre Ramón de Huesca y lo sería de nuevo por Porter y W.M. WhiteHILL, "An inscription on 1095 at Loarre", Speculum, III (1928), pp. 254-255.

34 No puedo recoger aquí la abundante bibliografía al respecto. Véase el somero estado de la cuestión proporcionado por J.A. MARTínez PRADES, El castillo de Loarre. Historia constructiva y valoración artística, Huesca, 2005, pp. 17-38 (en adelante citado: Martínez Prades, Loarre); y más recientemente por M. Poza YagüE, "Fortaleza militar y refugio de fe: proceso constructivo y relaciones estilísticas del conjunto de Loarre", Siete maravillas del románico español, Aguilar de Campoo, 2009, pp. 51-81 (en adelante: PozA, "Fortaleza"). 
dispersas incrustadas en una edificación que sigue ya las características generales del siglo XI" y consideraba "innegable la fusión de elementos de abolengo árabe y pirenaico" 35 . Estudios posteriores advirtieron la presencia de elementos arquitectónicos más antiguos que los de la gran iglesia en lo que mayoritariamente se viene considerando primer núcleo del castillo: el recinto superior, con sus dos grandes torres (convencionalmente llamadas de la Reina y del Homenaje) y un amplio espacio amurallado. Ha prevalecido la idea de que este ámbito estaría ya en pie cuando se documentan las primeras citas de tenentes (1033-1035). Íñiguez lo atribuía a Sancho el Mayor y Durán Gudiol, en la estela de Chamoso, lo juzgaba "castillo prerrománico", "perteneciente (...) al arte indígena con clara influencia mozárabe", datándolo durante el mismo reinado, en los años 1016-1025 $5^{36}$.

Frente a esta ubicación cronológica, mayoritaria entre los investigadores españoles $^{37}$, la caracterización del aparejo, la tipología de estancias donde prima lo residencial, la ostentación de su fábrica como signo de dominación cristiana, la necesidad de generación de recursos previos para tan magna construcción (parias) y el parangón con la práctica castellológica de los condados catalanes convencieron a Philippe Araguas de que este núcleo primitivo tenía que ser un poco posterior a $1040^{38}$. ¿No quedarían entonces restos materiales de la fortificación cuyos tenentes son citados en tiempos de Sancho el Mayor? Adolfo Castán ha llamado la atención sobre "una extraña torre situada en el ángulo noreste (...) recrecida con el mismo aparejo que las torres del Homenaje y de la Reina", por lo que ha de ser anterior, al igual que parte de los muros anejos en ambas direcciones. A su juicio correspondería a la primera fase ejecutada durante el reinado de Sancho III $^{39}$. El recinto alto con las torres de la Reina y del Homenaje sería posterior, bien del propio Sancho, bien de Ramiro I, hipótesis ésta última compatible con los argumentos de Araguas y que -en mi opinión- podría resolver adecuadamente algunos de los dilemas hasta

${ }_{35}$ M. Chamoso Lamas, "Revisión de formas constructivas en el castillo de Loarre", Archivo Español de Arte, 60, vol. XVI (1943), pp. 384-398.

${ }^{36}$ F. Í́̃IGUEZ Almech, "Las empresas constructivas de Sancho el Mayor. El castillo de Loarre", Archivo Español de Arte, XLIII (1970), pp. 363-373. A. Durán Gudiol, El castillo de Loarre, Huesca, 1971, p. 28.

${ }^{37}$ Martínez Prades considera que las torres de la Reina y del Homenaje datarían de tiempos de Sancho III, mientras que el aparejo algo diferente de la capilla de Santa María y de parte del recinto probaría su ejecución en tiempos de Ramiro I: Martínez Prades, Loarre, pp. 54-56.

38 Además del breve resumen publicado en 1973 ya citado, AraguAs, "Loarre", pp. 165-176; advierte paralelismo con los castillos de Arnau Mir de Tost que él mismo había estudiado en "Les châteaux d'Arnau Mir de Tost. Formation d'un grand domaine féodal en Catalogne au milieu du $\mathrm{XI}^{\mathrm{e}}$ siècle", Les pays de la Méditerranée Occidentale au Moyen Age. Études et recherches, Actes du $106^{e}$ Congrès national des Societés savantes, Perpignan, 1981, París, 1983, pp. 61-76. Comparte sus puntos de vista ViRuete, "Castillos", pp. 207-211, quien ha ajustado la ejecución al período entre 1049 y 1058. En la derivación de antecedentes catalanes coincide B. CABAÑERo SUBIZA, "La transición del prerrománico al románico en la castellología aragonesa y catalana", Les Cahiers de Saint-Michel de Cuxa, XXIII (1992), pp. 65-81.

39 A. Castán, Torres y Castillos del Alto Aragón, Huesca, 2004, p. 322. A falta de un estudio pormenorizado de módulos de sillares, aparentemente el aparejo de la torre nordeste coincide con lo que se estaba empleando en otros edificios de tiempos de Sancho el Mayor desde Luesia hasta La Rioja. 
ahora planteados por el conjunto fortificado. Sea de tiempos de Ramiro I o de su padre, para lo que aquí nos interesa el castillo de Loarre constituye la obra más ambiciosa de arquitectura militar emprendida por los monarcas que rigieron Aragón en los dos primeros tercios del siglo XI y un claro modelo a tener en cuenta por Sancho Ramírez.

\section{2. ¿Ramiro I? En torno a la primera fase constructiva de la catedral de Jaca}

Pasemos ya a considerar la promoción de grandes edificios religiosos por parte de Ramiro I (1035-1064 ${ }^{40}$ ), sometida igualmente a controversias que afectan a la datación de los más señalados: la catedral de Jaca y San Pedro de Siresa ${ }^{41}$.

La historiografía anterior a 1958 no había dudado en establecer que la seo jaquesa tal y como hoy la conocemos estaba en obras en la década de 1060 a instancias de Ramiro I, lo que la convertía en uno de los edificios pioneros en el desarrollo del Románico Pleno en España y Europa. Ya la primera monografía que trazó la historia catedralicia, publicada por Ramón de Huesca en 1802, afirmaba: "El rey don Ramiro antes de celebrar el Concilio hizo construir un magnífico templo de tres naves, todo de piedra, inclusa la bóveda, y una torre sobre la puerta mayor con ocho campanas, quatro grandes, dos medianas y dos pequeñas, en honor del Príncipe de los Apóstoles San Pedro, para colocar en él la sede episcopal”42. Los escritos de Del Arco en lo local y Gómez Moreno en lo nacional prueban que el vínculo entre el principal templo románico altoaragonés y el fundador de la dinastía se constituyó en principio básico sobre el cual apoyó su discurso la historiografía española los años sesenta ${ }^{43}$. Entre los estudiosos extranjeros, A. Kingsley Porter

\footnotetext{
40 Para el propósito de este estudio no resulta trascendente la polémica acerca de la fecha de la muerte de Ramiro I y el acceso al poder de Sancho Ramírez, por lo que aceptaremos la de 1064.

${ }^{41}$ Una visión muy reciente del arte en la época de Ramiro I en F. GaLTier MarTí, "Aragón en la época del beato de Fanlo", El beato del abad Banzo del monasterio de San Andrés de Fanlo, un Apocalipsis aragonés recuperado. Facsímil y estudios, Zaragoza, 2005, pp. 189-239; del mismo autor sobre el reinado y el arte: "Aragón, de los orígenes al esplendor: el reinado de Ramiro I", en I.G. BANGo ToRviso (Dir.), Sancho el Mayor y sus herederos. El linaje que europeizó los reinos hispanos, Pamplona, 2006, vol. I, pp. 146-156. B. CABANÉRo Subiza, Los orígenes de la arquitectura medieval de las Cinco Villas (891-1105): entre la tradición y la renovación, Ejea de los Caballeros, 1988, pp. 82-90, sitúa en el reinado de Ramiro I una fase constructiva de las iglesias de San Jacobo de Ruesta y San Nicolás de Ceñito, pero no las atribuye a la intervención directa del monarca.

${ }^{42}$ R. DE Huesca, Teatro histórico de las iglesias del Reyno de Aragon. Tomo VIII. De la Santa Iglesia de Jaca, Pamplona, 1802, p. 97. El texto del Padre Huesca parafrasea el llamado "documento del mercado" del que hablaremos a continuación.

${ }^{43}$ La atribución a Ramiro I en función de la documentación conservada en la propia catedral es patente en los estudios de J.M. Quadrado, Recuerdos y bellezas de España. Aragón, Barcelona, 1844, p. 175; Aragón, col. "España. Sus monumentos y artes. Su naturaleza e Historia", Barcelona, 1886, p. 295; J. DE CAVEDA, Ensayo histórico sobre los diversos géneros de arquitectura empleados en España desde la dominación
} 
hizo de la cronología temprana jaquesa uno de los argumentos en que apoyó su convencimiento de la prioridad de las obras españolas con respecto a las francesas en la famosa polémica acerca de los inicios del arte románico europeo resumida en la dicotomía Spain or Toulouse ${ }^{44}$.

En 1964 Antonio Ubieto Arteta demostró la falsedad de los tres diplomas en los que se basaba la cronología alta de la catedral ${ }^{45}$. En su opinión, las "actas del concilio de Jaca" (único de los tres en incluir datación tópica) habrían sido falsificadas en Roma entre abril de 1097 y mayo de 1098; la "donación de las trece iglesias" habría sido pergeñada hacia 1200; y el "documento del mercado", el único que contiene minuciosas referencias al estado de la construcción, en el siglo XIV ${ }^{46}$.

La inmediata respuesta de quienes defendían una secuencia perfectamente estructurada para los principales logros del románico hispano en los años sesenta y setenta de la undécima centuria vino de la pluma de Francisco Íñiguez, perfecto conocedor de la catedral debido a su trabajo como arquitecto restaurador (a él se debe el descubrimiento de muchos elementos constructivos ocultos por añadidos de siglos) ${ }^{47}$. Los razonamientos de Ubieto fueron finalmente aceptados por la mayor parte de la comunidad científica; no así la falsedad de los hechos que narran dichos diplomas. Se argumentó que una falsificación realizada antes de 1100 no podría contener datos erróneos sobre acontecimientos importantes celebrados menos de cuarenta años atrás, porque hubieran sido detectados por los destinatarios del diploma, con lo que el engaño no habría alcanzado su objetivo. Con este argumento, Canellas y San Vicente mantuvieron la atribución de parte de la fábrica al reinado de Ramiro I ${ }^{48}$.

romana hasta nuestros días, Madrid, 1848, p. 159; R. Del ARCO Y GARAY, “Aragón Monumental. La ciudad de Jaca", Boletín de la Sociedad Española de Excursiones, XXIX (1921), p. 172; y Catálogo Monumental de España. Huesca, Madrid, 1942, vol. I, p. 347; etc. Gómez Moreno, El arte románico, p. 66, considera que las obras se habrían iniciado después de 1054, "cuando Ramiro, una vez recobrado el reino aragonés, tuvo por su capital a Jaca".

44 Referencias concretas a Jaca aparecen en el artículo en que cristaliza la polémica: A.K. PORTER, "Spain or Toulouse? and Other Questions", The Art Bulletin, VII (1924), p. 12.

45 A. Ubieto Arteta, "El románico de la catedral jaquesa y su cronología”, Príncipe de Viana, XXV (1964), pp. 187-200; en 1958 el autor había presentado una comunicación sobre la cuestión en el III Congreso de Estudios Pirenaicos. ID., "La Catedral románica de Jaca. Problemas de cronologías", Pirineos, XVII-XVIII (1961-1962), pp. 125-137.

46 Las precisiones realizadas con posterioridad acerca de las fechas de falsificación de los diplomas no alteran lo sustancial: ninguno de los tres documentos es auténtico ni existió en tiempos de Ramiro I, por lo que no nos detendremos más en lo relativo a su datación. La "donación de las trece iglesias" explicita que San Pedro de Jaca había sido fundada por Ramiro I (donamus Deo et beato Petro Iaccensi ecclesiae... quam ecclesiam per nos esse fundatam). El documento "del mercado" contiene un expositivo completamente atípico en el Románico hispano, ya que los detalles constructivos que contiene no van dirigidos a establecer la tarea del arquitecto (como en el caso de Raimundo Lambard de la Seo de Urgel), sino a justificar una donación.

47 F. Í̃̃IGUEZ, "La catedral de Jaca y los orígenes del Románico en España”, Pirineos, n 83-86, XXIII (1967), pp. 179-201. Sobre su intervención en el edificio: ID., "La restauración de la Catedral de Jaca", Aragón, $\mathrm{n}^{\circ} 117$ (1935), pp. 99-101.

48 Canellas y San Vicente, Aragon, pp. 155-156. 
Cada uno de los tres documentos en cuestión tiene distinto peso a la hora de establecer la datación de la iglesia catedralicia. Dado que el contenido de las actas del concilio en nada alude a la construcción de un nuevo edificio, sino que se centra en la fijación de los límites diocesanos, un hipotético sínodo que hubiera dado origen (o justificación histórica) al diploma pudo igualmente haber tenido lugar en la iglesia de San Pedro del Viejo, por lo que no resulta conclusivo para lo que aquí nos interesa. Es mucho más importante el "documento del mercado", que describe al detalle el estado de la fábrica del templo en un momento en que se planteaba su terminación completamente abovedada ${ }^{49}$. Se ha dicho que el texto describe con exactitud cómo estaría el edificio en la fase previa a la culminación de las cubiertas, todavía en el siglo XI. Pero no es menos cierto que la descripción también habría sido pertinente si alguien en los siglos XII o XIII hubiera deseado abovedar un edificio que estaba cubierto de madera y con la torre sin concluir. Pese a haberlo buscado afanosamente, Íñiguez no encontró ningún vestigio de abovedamiento de la nave central en época románica ${ }^{50}$. Al respecto, se ha invocado en ocasiones la tipología de los pilares, que parecen pensados para sustentar bóvedas de arista, pero la actual ausencia de los correspondientes apeos en los muros los aleja de las fórmulas habituales en el pretendido foco de origen de esta solución (Italia). Para una ajustada valoración de la alternancia de soportes en la seo, será preciso proceder a un examen (que no haremos aquí) de todas las posibilidades, no sólo de cubiertas, sino también de secuencias espaciales, dado que dicha solución ha sido utilizada en la arquitectura románica con más de una finalidad.

Recientemente tanto Esteban como Galtier y Cabañero han analizado respectivamente las proporciones y la materialidad (aparejo y composición) de la edificación catedralicia para concluir que el proyecto inicial de la cabecera habría sido ejecutado durante el reinado de Ramiro I en lo correspondiente al trazado de los ábsides y al menos la cimentación y primeras hiladas del septentrional. Juan Francisco Esteban ha razonado, a partir de estudios metrológicos, que el sistema de proporciones empleado en la cabecera, basado en la geometría del triángulo equilátero, es diferente del utilizado en fases posteriores del edificio. El arquitecto que lo diseñó "debió de construir al menos la parte baja del ábside norte (que tiene un paramento exterior de aspecto lombardo)" "51. Ubica esta campaña "en los años

49 Sobre la teoría de que los documentos de Ramiro I en realidad se refieren a San Pedro el Viejo (que las excavaciones de este templo han desmentido) véase A. Durán Gudiol, El monasterio de San Pedro de Siresa, Zaragoza, 1989, pp. 24-26.

50 Para las laterales habla de manera poco concreta: "sobre las naves bajas no es aventurado suponer bóvedas de arista; encajan perfectamente y han dejado algún que otro vestigio". En la central no tiene dudas: "Para la nave mayor, tan ancha, alta y con luces directas, no hay bóveda conocida entonces que pueda suponerse con probabilidades de certeza": F. Í̃̃IGUEZ, "La restauración de la Catedral de Jaca", Aragón, 117 (1935), p. 101.

51 J.F. Esteban Lorente, “La metrología de la catedral románica de Jaca: 1”, Artigrama, 14 (1999), pp. 241-262; ID., "La metrología de la catedral románica de Jaca: 2”, Artigrama, 15 (2000), pp. 231-258; la cita en p. 256 del segundo artículo. 
de la mitad del siglo XI”. En una publicación posterior aventura una datación más exacta: "el inicio de los ábsides en una tradición lombarda quizá antes de 1063" . Galtier relaciona directamente las obras primerizas de la catedral "con el estilo que había marcado la primera fase de Santa María de Iguácel"53.

El quid de la cuestión radica en determinar si hubo o no una fase inicial a la que correspondiera el planteamiento y el comienzo material de la edificación, y en la que sólo se ejecutaran labores de cimentación y elevación de primeras hiladas de uno o más ábsides. Y si dicha hipotética fase inicial es diferenciable en el tiempo y en las formas con respecto a una segunda fase caracterizada por la incorporación de elementos de articulación plástica (molduras, columnas) y complementos escultóricos (capiteles, canecillos, metopas, etc.) propios del Románico Pleno. Para dirimir el asunto he procedido a la medición de la secuencia de hiladas inferiores del ábside septentrional y a su comparación con secuencias constructivas a lo largo de todo el edificio catedralicio. En paralelo, he comprobado si existe o no un cambio perceptible en el trabajo de la piedra entre dichas hiladas inferiores y el resto de la fábrica de ábsides y muros.

En el ábside septentrional quedan hoy a la vista dos hiladas de cimentación sobre las que arranca el semicilindro absidal, recorrido verticalmente por un elemento en resalte (¿lesena, zócalo?). Las hiladas del semicilindro responden a las siguientes medidas, de abajo hacia arriba: 14, 14, 19, 20, 14, 38, 30, 49 (hilada luego dividida), 12 y $39 \mathrm{~cm}$ (hilada labrada en plano oblicuo). Es rasgo destacable la existencia de varias hiladas seguidas de $20 \mathrm{~cm}$ o menos, claramente de dimensiones menores que las que se ven en el ábside meridional (de abajo hacia arriba: 17, 40, 38,27 y $19 \mathrm{~cm}$, ésta última por debajo de la oblicua). No extraña que la contemplación de esta secuencia haya persuadido a más de un investigador a pensar que la parte inferior del ábside septentrional correspondía a una primera fase, a la que siguió otra diferente y más tardía en que predominarán las hiladas de mayor altura. Pero cuando se analiza de manera pormenorizada la totalidad de los paramentos de la catedral, encontramos secuencias semejantes en otros lugares a distintas alturas. En la esquina norte del ábside meridional (interior) medimos la siguiente: 17, 19, 14, 13, 17, 14, 41, 20, 27 y $31 \mathrm{~cm}$; en el muro sur del anteábside meridional: 14, 20,

52 ID., "La metrología y sus consecuencias en las iglesias de la Alta Edad Media Española. IV. El románico del último tercio del siglo XI”, Artigrama, 23 (2008), p. 388.

53 "De hecho, en la catedral, la parte baja del exterior de los ábsides meridional y septentrional -cuya cara externa la conocemos desde hace pocos años- presenta un tipo semejante de trabajo de la piedra y la misma forma de pilastras que en Iguácel": F. GALTiER MARTí, "La catedral de Jaca y el románico jaqués", en J.L. Ona GonzÁlez y S. SÁnchez Lanaspa (coords.), Comarca de La Jacetania, Zaragoza, 2004, p. 138. Cabañero ha concretado que las siete primeras hiladas que una reciente intervención ha dejado a la vista en dicho ábside septentrional responden al sistema constructivo propio de los canteros "lombardistas", siendo apreciable "incluso el plano rehundido, delimitado por la lesena medial del lado norte, que debió ser concebido para estar coronado por arquillos ciegos". Por encima aparece ya la "sillería del primer arte jaqués, que coincide por sus dimensiones y modo de talla con la del basamento del ábside meridional": CABAÑERO, "Precedentes", pp. 231-232. 
17, 18, 37, 37, 17 y $27 \mathrm{~cm}$; en el muro sur del anteábside central: 9, 16, 22, 16, 16, $27,15,31,20$ y $32 \mathrm{~cm}$; en el centro del muro norte: $29,19,15,12,12,9,10,30$, $28 \mathrm{~cm}$; en la parte alta del muro meridional junto a la puerta y en el pilar toral del lado del evangelio se observan igualmente secuencias de hiladas de escasa altura, parangonables con la del ábside septentrional. Ha de concluirse que una secuencia de este tipo no se corresponde necesariamente con una fase distinta, ya que es una constante la falta de regularidad del aparejo de la catedral y, dentro de dicha irregularidad, no son raras las secuencias de varias hiladas de escasa altura.

Del mismo modo, la manera como están trabajadas las hiladas bajas del ábside norte no se diferencia ni en la labra de la piedra ni en el modo de asentar las hiladas (con tendeles estrechos), con respecto a lo que encontramos en otros lugares de la catedral. Y la piedra empleada en unas y otras es aparentemente semejante (fig. 2).

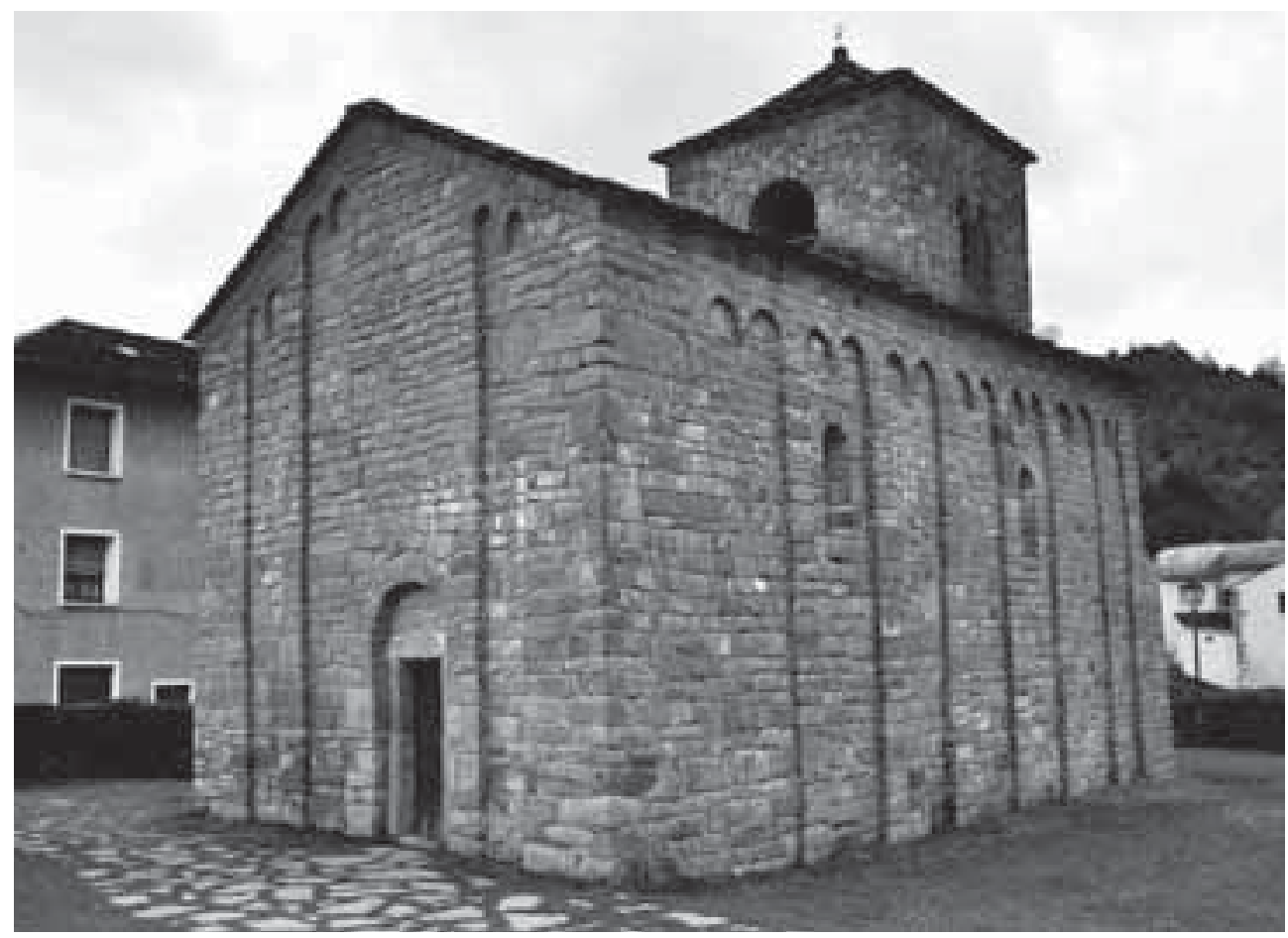

Fig. 2. San Caprasio de Santa Cruz de la Serós

El elemento en resalte del ábside septentrional, que ha sido interpretado por Cabañero como una lesena de tradición lombarda ${ }^{54}$ destinada a su coronación por arquillos ciegos, tiene una anchura en su frente de $48 \mathrm{~cm}$ y sobresale $16-18 \mathrm{~cm}$

\footnotetext{
54 Véase nota anterior.
} 


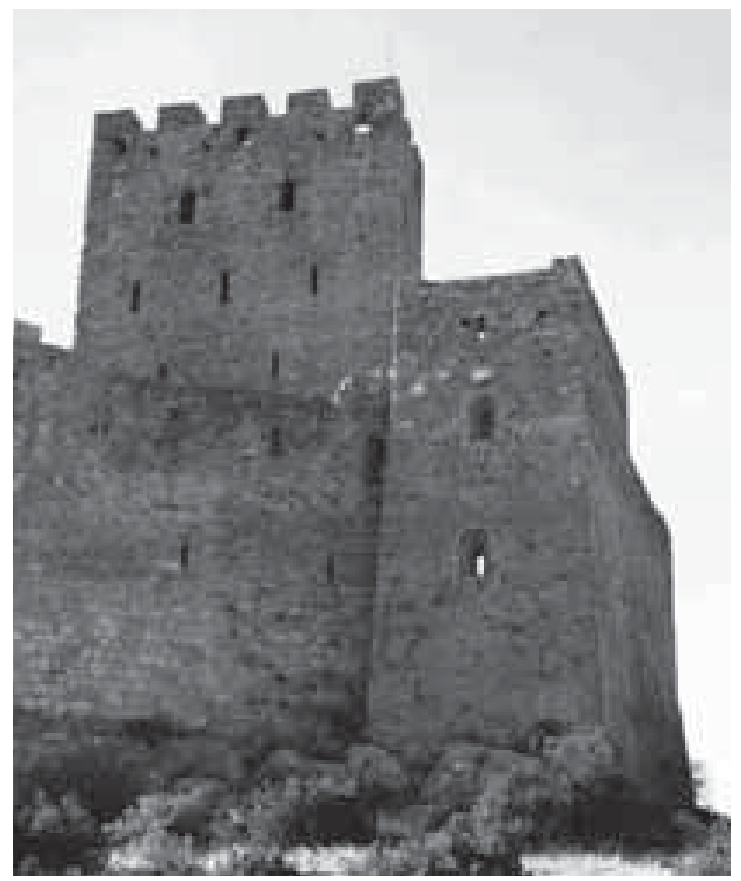

Fig. 3. Castillo de Loarre, torre del ángulo noreste

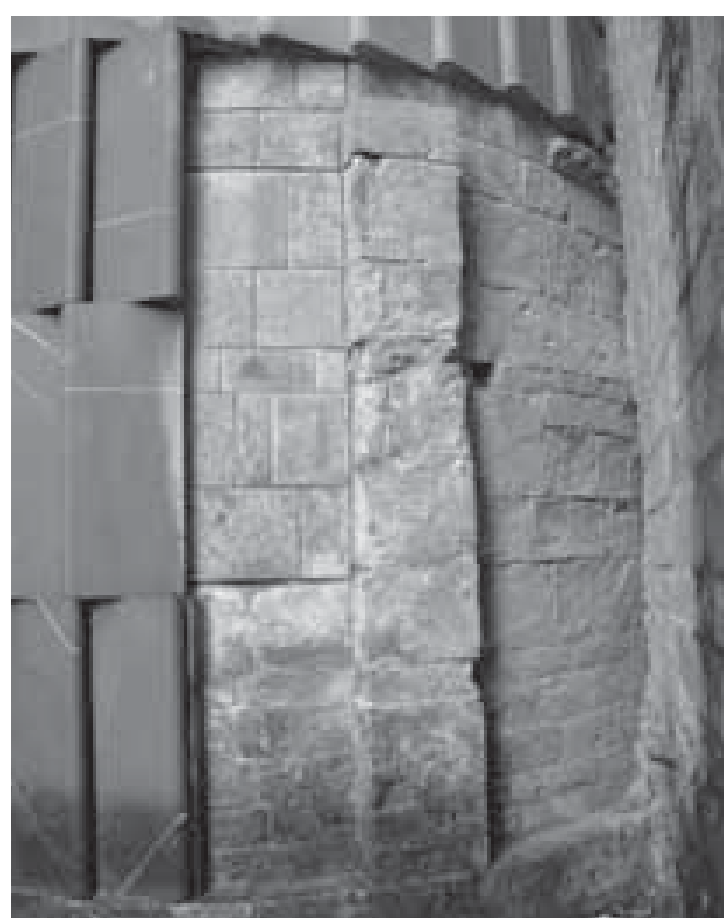

Fig. 4. Catedral de Jaca. Detalle de ábside septentrional con respecto al muro. Justamente son las mismas dimensiones del zócalo en que asienta la columna del ábside meridional (fig. 3), que coincide en $48 \mathrm{~cm}$ de frente y 17 $\mathrm{cm}$ de resalte (más arriba gana relieve, por encima de la hilada oblicua). La colocación de la hilada oblicua y sus dimensiones $(39 \mathrm{~cm})$ son idénticas en ambos ábsides.

El efecto visual diferente que percibimos al contemplar ambos semicilindros obedece a que vemos más hiladas en el ábside norte por estar el pavimento externo a un nivel muy inferior (casi un metro por debajo). Todas estas observaciones conducen a pensar que los dos ábsides se hicieron de una vez, con las mismas medidas, y que el hecho de que haya varias hiladas de escasa altura en el septentrional tiene la misma relevancia aquí que cuando varias hiladas de escasa altura se emplean en otros lugares del edificio, es decir, ninguna a la hora de diferenciar fases constructivas del edificio. Estas conclusiones son todavía más firmes si comparamos el aparejo de los ábsides, tanto abajo como arriba, con el empleado en el edificio jacetano que podemos vincular más directamente con el primer románico meridional: San Caprasio de Santa Cruz de la Serós (fig. 4). Allí las hiladas son mucho más irregulares, con predominio de la escasa altura (secuencia escogida al azar, por ejemplo, de 14, 20, 20, 12, 28, 12 , $21,9,5,12,12)$ con tendeles muy 
grandes $(2-3,5 \mathrm{~cm})$ capaces de absorber las enormes diferencias (fácilmente de 2 $\mathrm{cm}$ ) entre un extremo y otro de un mismo sillarejo (fig. 6). Y la labra es completamente distinta, con superficies muy rugosas y volumétricamente dispares. Las lesenas sobresalen entre 10 y $13 \mathrm{~cm}$ (mucho menos que los zócalos de Jaca) y tienen anchura de frente menor e irregular (entre 25 y $42 \mathrm{~cm}$, con gran variedad). En cuanto a las semejanzas entre el aparejo del ábside de Jaca (fig. 5) y el de Iguácel, a mi juicio no proporcionan un dato cronológico adicional justificativo de una obra de tiempos de Ramiro I, porque -como intentaré mostrar más adelante- la iglesia de la Garcipollera deriva en todos sus elementos (incluido el aparejo) de la fábrica catedralicia tal y como fue construida en su fase del Románico Pleno durante el reinado de Sancho Ramírez.

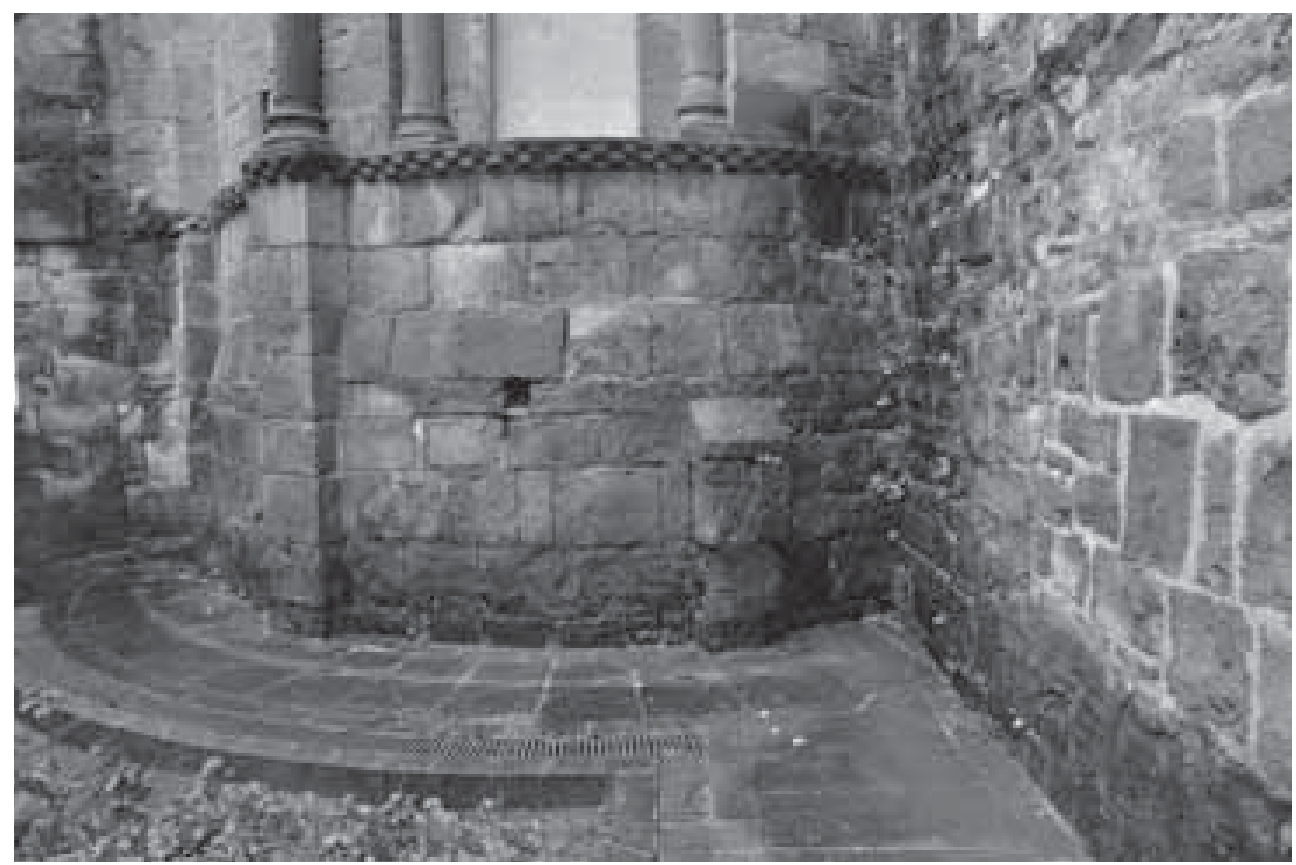

Fig. 5. Catedral de Jaca. Detalle de ábside meridional

No encuentro razones, por tanto, para admitir un primer proyecto catedralicio elaborado por un primer maestro o taller "lombardista" (de tiempos de Ramiro I), que hubiera sido sustituido por otro al que cabría atribuir la continuación del ábside septentrional y la totalidad del meridional, así como los muros perimetrales de las naves. Las razones para fechar el comienzo del proyecto catedralicio en tiempos de Sancho Ramírez serán expuestas más adelante, cuando retomemos la cuestión al hablar de las empresas arquitectónicas de este monarca. 


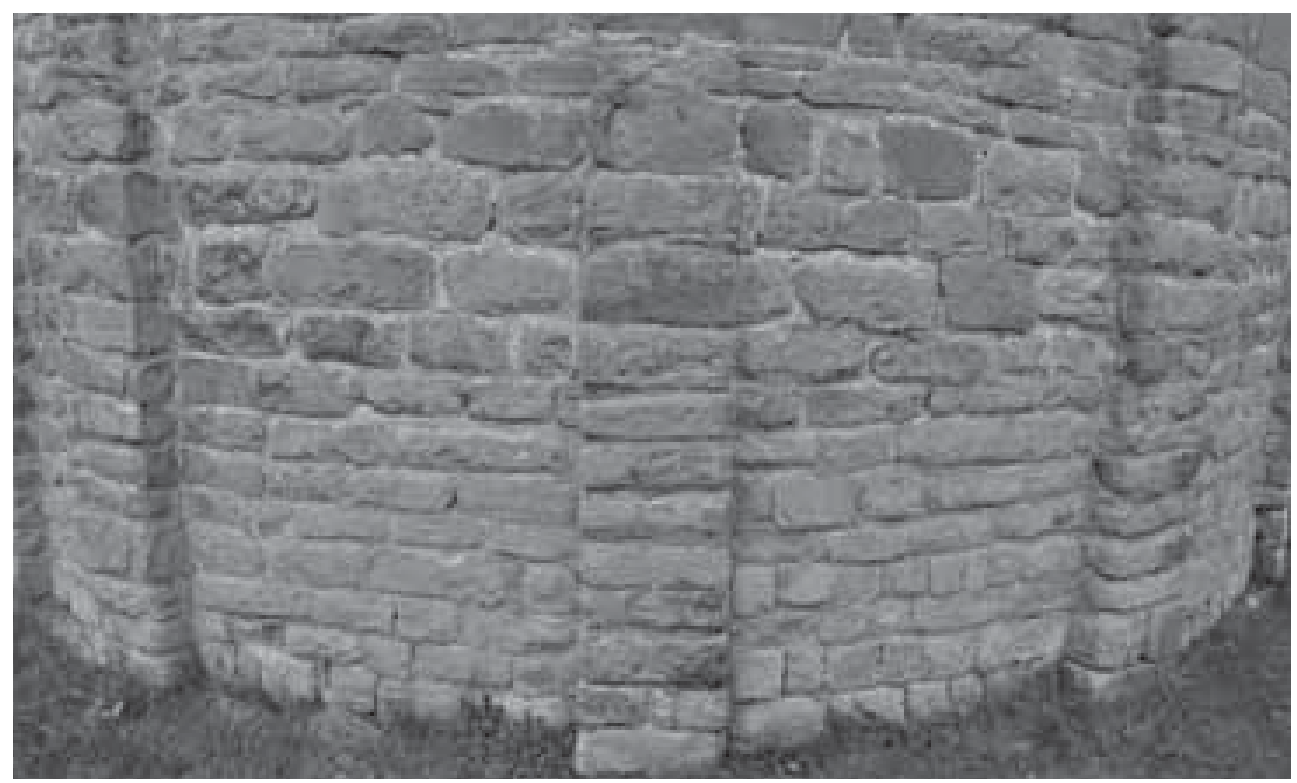

Fig. 6. Detalle del ábside de San Caprasio de Santa Cruz de la Serós

\section{Sobre la atribución de Siresa y de diversos castillos a la promoción de Ramiro I}

Examinemos ahora San Pedro de Siresa (fig. 7), edificio de dimensiones inesperadas por su amplitud, que despliega una peculiar combinación de plasticidad mural y ausencia de complemento escultórico. Aunque han sido estudiados con acierto algunos de sus elementos, su arquitectura está falta de una monografía extensa que la analice en su integridad con el pertinente detenimiento. Las opiniones acerca del desarrollo de su construcción resultan muy diversas. Fuentes medievales tardías la atribuyeron a Ramiro I y a Sancho Ramírez, y así fue recogido por Ramón de Huesca. El primer historiador del arte que se ocupó de la construcción, Ricardo del Arco, en 1919 la dató "siquiera su parte principal de cabecera y crucero" hacia 1082 (cuando el soberano la constituye capilla regia), mientras que la nave a su juicio sería "un poco posterior, ya entrando en el siglo XII"55. Esta datación en tiempos de Sancho Ramírez halló refrendo internacional en escritos de Crozet, Durliat y Heitz ${ }^{56}$. Por el contrario, Durán Gudiol defendió su ejecución en época

55 R. DEl Arco, "El Real Monasterio de Siresa, Capilla Real de Aragón”, Boletín de la Sociedad Española de Excursiones, XXVII (1919), pp. 300-301.

56 J. Gudiol Ricart y J.A. Gaya Nuño, Arquitectura y escultura románicas, vol. V de la col. "Ars Hispaniae", Madrid, 1948, pp. 117-119; M. DuRliat, El arte románico en España, Barcelona, 1964, p. 66; CANELLAS y San Vicente, Aragon, pp. 297-300; C. Heitz, "Éléments carolingiens dans l'architecture méditérranéenne", Les Cahiers de Saint-Michel de Cuxa, 12 (1981), p.119. 


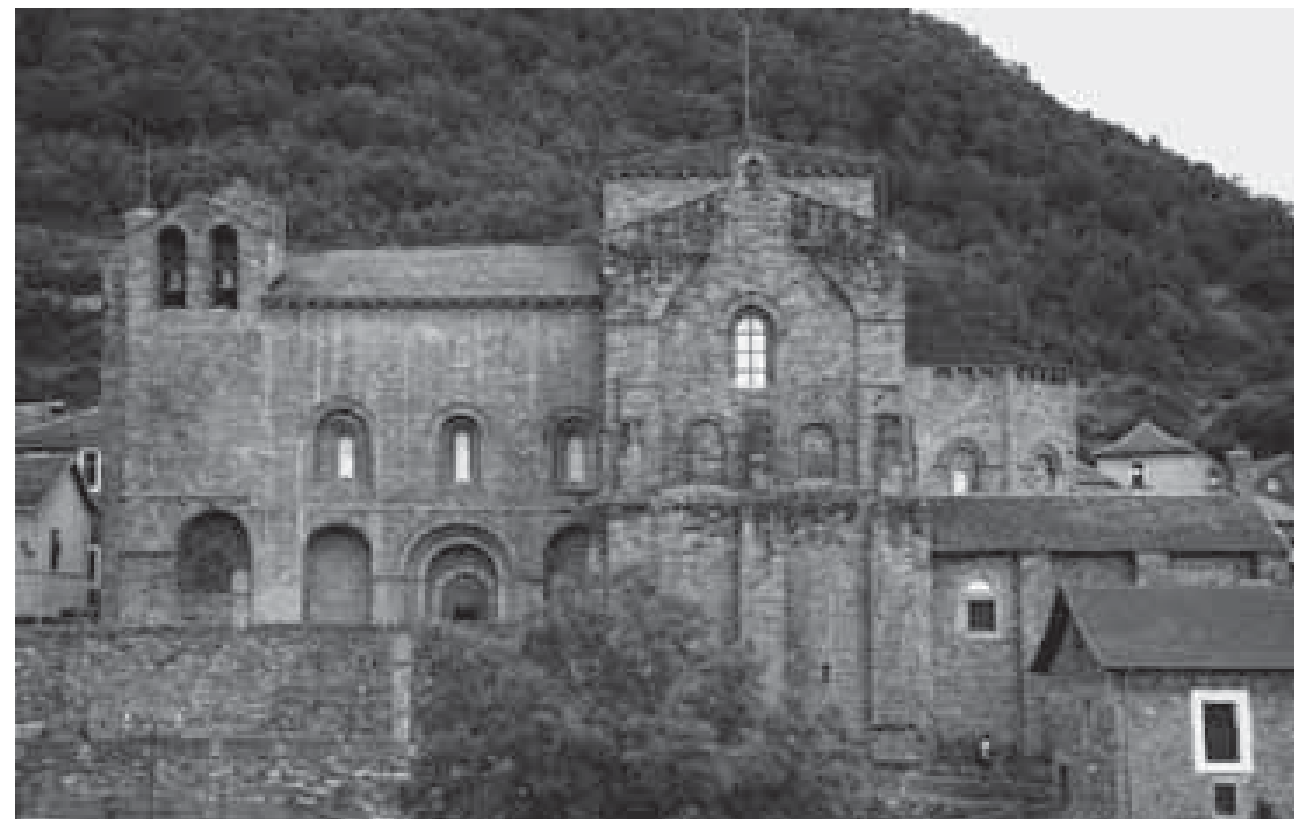

Fig. 7. San Pedro de Siresa

carolingia, comparando indiscriminadamente alguna de sus soluciones con lo existente en ciertos templos franceses, alemanes o suizos ${ }^{57}$. El hallazgo reciente de la cimentación del edificio prerrománico descarta completamente la hipótesis de que lo que hoy vemos en pie corresponda a una obra anterior al siglo $\mathrm{XI}^{58}$. Aunque ningún documento relaciona directamente al monarca con su fábrica, Fernando Galtier recuperó la atribución bajomedieval y supuso que Ramiro I emprendió la reconstrucción de la vieja iglesia que habría sufrido los efectos desastrosos de la razia de Almanzor del año $999^{59}$. En su opinión, las obras avanzaron con lentitud,

57 A. Durán Gudiol, El monasterio de San Pedro de Siresa, Zaragoza, 1989, pp. 17-19; ID., "Dos cuestiones sobre el monasterio de San Pedro de Siresa", Príncipe de Viana, LII (1991), pp. 7-14. Como ha sucedido con San Pedro el Viejo de Jaca, también las excavaciones de Siresa han venido a desmentir las hipótesis de Durán.

58 R. Puertas Tricas, Excavación en San Pedro de Siresa, Huesca, 1993. Aun siendo consciente de que su opinión era minoritaria, Durán Gudiol mantuvo su hipótesis de tratarse de "un ejemplar carolingio del siglo IX" suponiendo que lo excavado correspondía a "una iglesia dedicada a San Juan, cuyos fundamentos ha puesto de manifiesto una reciente excavación": "Arquitectura Altoaragonesa. Siglos VIII-XI", Signos. Arte y Cultura en el Alto Aragón Medieval, Jaca-Huesca, 1993, pp. 87- 93. Tampoco ha tenido aceptación la teoría de Uranga e Íñiguez a la hora de fechar en tiempos de Sancho III el Mayor la portada occidental del templo: "Por sus dovelas delgadas, parejas de la iglesia de San Pedro de Roda": URAnga e Í̃̃gueZ, Arte medieval, vol. I, p. 237.

59 F. Galtier Martí, "Le corps occidental des églises dans l'art roman espagnol du XI s.: problèmes de réception d'un modèle septentrional", Cahiers de Civilisation Médiévale, XXXIV (1991), pp. 304-305 y 307. A la hora de datarla en tiempos de Ramiro I, considera sintomático que hubiera un tenente en Siresa en 1042. No está de más recordar que las noticias del ataque cordobés no incluyen explícitamente su extensión a este rincón pirenaico y no se han hallado vestigios de destrucción violenta del edificio previo. 
iniciadas por la cabecera y proseguidas por el bloque occidental, el que más le ha interesado analizar. El proyecto inicial habría sido modificado y la obra no habría quedado concluida hasta finales del siglo XI, lo que le habría conferido su aspecto particular. La existencia de un cuerpo occidental, de enorme interés desde el punto de vista tipológico y funcional (Crozet y Heitz lo habían vinculado con tradiciones carolingias), tendría que ver -según Galtier- con el hecho de haber sido "el principal convento del núcleo primitivo del condado de Aragón y el centro religioso más privilegiado por sus soberanos en los siglos IX y X", que todavía gozaba de la protección real en las últimas décadas del siglo XI y primeras del XII (capilla regia "presidida" por la condesa Sancha donde Alfonso I recibió educación). En otra publicación, el mismo autor especifica que de tiempos de Ramiro I sólo queda como vestigio el núcleo interior del macizo occidental ${ }^{60}$. Por su parte, el estudio metrológico aplicado por Esteban le llevó a afirmar que los planes proyectuales del edificio actual "no pueden ser anteriores al último tercio del siglo XI"61.

La atribución del proyecto del edificio actual de Siresa a Ramiro I cuenta con tres inconvenientes que en mi opinión descartan la hipótesis: a) desde el punto de vista documental, durante su reinado sólo aparece mencionado su abad en un documento de su colección diplomática, y además figura como testigo, sin que exista donación ni relación directa con el rey ${ }^{62}$; b) no se ha justificado suficientemente el recurso a una cabecera de exterior poligonal e interior semicircular en esos años centrales de la undécima centuria; y c) la monumentalidad del edificio (dimensiones, complejidad plástica) es ajena a lo que sabemos de la arquitectura religiosa aragonesa (incluso pirenaica en lo concerniente al segundo aspecto) de esa época.

En cuanto a la arquitectura civil auspiciada por Ramiro I, ya se ha mencionado su posible protagonismo en las obras de Loarre; además, la preocupación general por los castillos le llevó a reservar en sus testamentos una parte de sus bienes muebles ad castros de fronteras de mauros qui sunt pro facere (1059) e in castellos de fronteras de mauros qui sunt per fare (1061), tarea a la que según Viruete se habría comprometido gracias a los recursos conseguidos a partir de los años 1047-1048, dentro de una política volcada a la expansión del reino a costa de los andalusíes. Con relación a esta actividad le han sido atribuidas intervenciones en numerosos castillos: Marcuello, Peña, Sibirana, Sos, Uncastillo, Fantova, Fals, Laguarres, Abizanda, Boltaña, Morcat, Sarsa de Surta, Surta, Troncedo, Almazorre,

${ }^{60}$ F. Galtier Martí, “Les conditions et les développements de l'art préroman et les débuts de l'art roman dans les comtés de Ribagorza et d'Aragon", Simposi internacional d'arquitectura a Catalunya (Girona, 1988). Segles IX, X i primera meitat de l'XI, Gerona, 1994 p. 92 . Un desarrollo semejante fue asumido por Cabañero (comienzo "en los años centrales del siglo XI"): véase la nota siguiente.

${ }^{61}$ Las opiniones de Cabañero y Esteban, ligeramente divergentes, aparecen en distintas partes de un artículo que encabezaron de manera conjunta y firmaron por separado: B. CABAÑERo SUBIZA, J.F. EsTEBAN Lorente y M. García Guatas, "Siresa. Crónica de una restauración polémica”, Artigrama, 6-7 (1989-1990), pp. 283, 291 y 294.

62 Viruete, Aragón, vol. II. 
Arcusa, Clamosa, Escanilla, Los Santos, Miravet, Moro Maior, Pano, Rodellar y Castelmanco ${ }^{63}$. No es preciso discutir caso por caso para dirimir la cronología de cada uno. Nos basta el contenido de los testamentos para afirmar que la política de incremento de fortalezas que llevará a cabo Sancho Ramírez tenía precedentes de gran importancia en la actuación de su padre y sus antepasados.

También los puentes aparecen expresamente citados en los testamentos del rey (cuya autenticidad no merece la pena discutir aquí). El temprano reino de Aragón estaba constituido por una yuxtaposición de valles fluviales de dirección Norte-Sur, que era preciso articular favoreciendo la comunicación Este-Oeste. Obras como el puente de Cacabiello y el del Aragón, expresamente citados en el testamento de 1059 (et si isto ponte de Kakaviello non fuerit complito, de ipsum se compleat; et quando ipso fuerit complito, faciant alio in Aragone), perseguían este objetivo ${ }^{64}$.

En resumen, en la tradición aragonesa se había producido un incremento progresivo en las dimensiones y calidad de los edificios, mayor en los civiles que en los religiosos, desde el siglo X hasta 1064. El protagonismo de los relacionados con quienes ejercían el poder se acusaba especialmente en el campo de las fortificaciones. Sin embargo, ni la recepción de nuevas fórmulas constructivas ni la ambición arquitectónica sobrepasaba lo que podía encontrarse en territorios vecinos, salvo el caso del castillo de Loarre. Desde luego, ningún encargo religioso había supuesto una ruptura con la tradición del calibre de lo que habían significado San Salvador de Leire, Santa María de Ripoll o San Vicente de Cardona con respecto a sus respectivos antecedentes en cada uno de los correspondientes territorios.

\section{Antecedentes II: los encargos arquitectónicos de la monarquía pamplonesa}

Por lo que respecta a la promoción de encargos arquitectónicos por la monarquía pamplonesa, el panorama del siglo $\mathrm{X}$ resulta insuficientemente conocido, pese a las valiosas aportaciones de Uranga e Íñiguez ${ }^{65}$. Dentro de la denominada "Navarra primordial", son muy escasos los edificios conservados erigidos en época prerrománica y sólo uno de ellos, San Miguel de Villatuerta, contiene elementos

63 Sobre la "planificación militar defensiva de Ramiro I": M. GARCíA GuATAs, "El castillo de Abizanda, en la frontera de la reconquista aragonesa", Homenaje a don José María Lacarra de Miguel en su jubilación del profesorado. Estudios medievales, I, Zaragoza, 1977, pp. 121-133. Sobre los castillos de este rey en Cinco Villas: B. CABAÑERo Subiza, Los orígenes de la arquitectura medieval de las Cinco Villas (891-1105): entre la tradición y la renovación, Ejea de los Caballeros, 1988, pp. 59-81. En general sobre los castillos del monarca: R. Viruete ERdozÁin, “Castillos”; cfr. también la tesis doctoral del mismo autor ya citada.

64 A. Ubieto Arteta, Cartulario de San Juan de la Peña, Valencia, 1962-1963, doc. 150, pp. 177-181.

65 Uranga e ÍñIgueZ, Arte Medieval, vol. I. 
que permiten vincularlo con los reyes y fecharlo a finales de la décima centuria ${ }^{66}$. No deja de ser un edificio modesto, de nave única y cabecera semicircular, ubicado en un lugar de gran valor estratégico (dominaba un vado fluvial cruzado por los andalusíes en sus campañas), lo que pudo haber motivado la inclusión en sus paredes de relieves que representaban el rito celebrado cuando el rey iba a partir contra sus enemigos ${ }^{67}$. El elenco de construcciones de las tierras riojanas es más rico en número y variedad; no obstante, en ningún caso se trata de empresas de grandes dimensiones y la participación de los monarcas, salvo en San Millán de la Cogolla, es discutible.

Las fortificaciones del siglo X en los territorios de Pamplona y Nájera han sido objeto de una valiosa aproximación por parte de Cabañero ${ }^{68}$. En su opinión, la fase inicial caracterizada por el recurso a empalizadas rudimentarias (siglo IX) y uso de cuevas y galerías subterráneas como refugio, en ocasiones fortificadas (Viguera, cuya iglesia castrense sería San Esteban), fue seguida por la construcción de fortalezas lignarias (Santa María de la Piscina, Falces), cuyas estructuras fueron a su vez sustituidas por encofrados con pilares angulares propios de las técnicas del tapial (Peralta, hacia 930, con su iglesia castrense de Santa Lucía; también Arnedillo y Falces). La torre circular y exenta en Rada, relacionable con torres catalanas de la misma planta del siglo X, nos sitúa ante una construcción erigida en sillería con paralelos anteriores al año mil. Ninguna de estas construcciones, como tampoco la torre de Javier y su recinto (para los que invoca parentescos con obras aragonesas, Añués y Ruesta, ésta última ya en tiempos de Sancho el Mayor) va más allá de su funcionalidad defensiva. En resumen, ninguna fortificación navarra conocida se aproximaba a las grandes creaciones de la castellología aragonesa de la primera mitad del siglo XI.

La figura de Sancho III el Mayor (1004-1035) ha despertado enorme interés entre los antiguos cronistas y los modernos historiadores. En 1970 Francisco İñiguez dedicó un artículo a sus "empresas constructivas", donde pasaba revista a San Millán de la Cogolla, San Juan de la Peña, las iglesias de Serrablo y la catedral de Palencia, además del ya citado castillo de Loarre ${ }^{69}$. En 2003 Janice Mann planteó

\footnotetext{
${ }^{66}$ Me he ocupado de los encargos artísticos de los reyes y de la significación de los cambios arquitectónicos en la Navarra de los siglos X-XI en J. Martínez de AguirRe Aldaz, "Creación de imágenes al servicio de la monarquía" y "Hacia la monumentalización del reino", Signos de identidad histórica para Navarra, Pamplona, 1996, I, pp. 187-202 y 271-288.

${ }^{67}$ Estudiados por S. De SiLVA y Verástegui, Iconografía del Siglo X en el Reino de Pamplona-Nájera, Pamplona, 1984, pp. 158-161.

${ }^{68}$ B. CabaÑero Subiza, "De las cuevas a los primeros castillos de piedra: algunos problemas del origen de la castellología altomedieval en el norte peninsular", Turiaso, 6 (1985), pp. 165-188; ID., "Los castillos de La Rioja construidos frente al dominio del Islam. Notas sobre su origen", Cuadernos de investigaciones históricas Brocar, 16 (1990), pp. 19-40; ID., "La defensa del reino de Pamplona-Nájera en el siglo X. Materiales para el estudio de la evolución de sus castillos", La Marche Supérieure d'Al Andalus et l'Occident chrétien, Madrid, 1991, pp. 99-119.

69 F. Í̃̃IGUEZ Almech, "Las empresas constructivas de Sancho el Mayor. El castillo de Loarre", Archivo Español de Arte, XLIII (1970), pp. 363-373.
} 
una revisión entendiendo que la nueva arquitectura del soberano voluntariamente preservaba los vestigios de edificaciones previas, lo que hacía visible el nexo entre el pasado preislámico y el presente victorioso que él mismo representaba ${ }^{70}$. Con motivo del milenario de su acceso al trono, se ha retrazado su trayectoria en publicaciones y en la magna exposición dedicada a su figura y herederos, de la que fue comisario Isidro Bango (Pamplona, 2006) ${ }^{71}$.

Parece haber sido su principal encargo arquitectónico religioso la iglesia de la abadía de Leire, donde durante su reinado y muy probablemente con su apoyo fue emprendida una monumental cabecera con soluciones prestigiosas (sillares cuyas hiladas llegan a alcanzar alturas superiores a $70 \mathrm{~cm}$, cripta de cuatro naves extendida bajo las tres naves de la cabecera y constituida por alternancia de pilares y columnas, novedoso repertorio ornamental un tanto tosco, iglesia de tres naves abovedadas alcanzando la central $10,60 \mathrm{~m}$ de altura, pasillo igualmente abovedado a los pies de la cripta, portadas abocinadas con arquivoltas, etc.), varias de las cuales suponían novedad en el panorama hispano ${ }^{72}$. El edificio habría sido consagrado en 1057, más de veinte años después del fallecimiento del monarca que lo inició, por lo que no extrañan las expresiones del rey García Sánchez III acerca del retraso ${ }^{73}$. Estimo muy probable un apoyo económico directo a las obras por parte del monarca (lo hacía asimismo con empresas artísticas en Cluny), que se beneficiaron de la decisión del rey de elevar al abad Sancho al episcopado pamplonés, con las rentas que ello comportaba. Muy posiblemente el soberano y el abad coincidieron en el deseo de que la ampliación del edificio prerrománico manifestara a un tiempo el nuevo rumbo que emprendía el monasterio y la circunstancia de ser iglesia propia de quien dominaba todo el Norte peninsular, desde Ribagorza hasta Galicia.

En cuanto a San Millán de la Cogolla, las fuentes documentales y las circunstancias que vivió en las primeras décadas del siglo XI hacen muy verosímil la participación del rey en la ampliación de la iglesia de Suso, con una construcción un tanto

70 J. ManN, “A New Architecture for a new Order: The Building Projects of Sancho el Mayor (10041035)", en N. Hiscock, The White Mantel of Churches: Architecture, Liturgy and Art around the Millennium, Turnhout, 2003, pp. 232-248; ID., Romanesque Architecture and its Sculptural Decoration in Christian Spain, 1100-1200, Toronto, 2009, dedica el segundo capítulo al patronazgo arquitectónico de Sancho el Mayor, pp. 46-74.

71 I.G. BAngo Torviso (Dir.), Sancho el Mayor y sus herederos. El linaje que europeizó los reinos hispanos, Pamplona, 2006, 2 vols. Desde el punto de vista histórico destaca A. MarTín DuQue, Sancho III el Mayor de Pamplona. El rey y su reino (1004-1035), Pamplona, 2007.

72 J. Martínez de Aguirre, "L'art au temps de Sancho III el Mayor: Leire”, Les Cahiers de Saint-Michel de Cuxa, XL (2009), pp. 237-250.

${ }^{73}$ La correcta datación de cripta e iglesia fue publicada por J.M. LACARRA y J. GudIOL, "El primer románico en Navarra. Estudio histórico arqueológico", Príncipe de Viana, V (1944), pp. 221-272. Sobre la materialidad del edificio consagrado en 1057 es fundamental F. ÍñIGUEZ AlmECH, "El monasterio de San Salvador de Leyre", Príncipe de Viana, XXVII (1966), pp. 189-220; y sobre su escultura: J. CABANOT, “Les débuts de la sculpture romane en Navarre: San Salvador de Leyre", Les Cahiers de Saint-Michel de Cuxa, 9 (1978), pp. 21-50. Bibliografía completa en J. Martínez de Aguirre, voz “Leire”, Enciclopedia del Románico en Navarra, Aguilar de Campoo, 2008, vol. III, pp. 1503-1535. 
rudimentaria. En cambio, pienso que la atribución de la cripta de San Antolín en la catedral de Palencia a la iniciativa del monarca es poco defendible, dada la falsedad manifiesta del diploma en que se basa (según Gonzalo Martínez ${ }^{74}$ ); mucho más digna de crédito es la atribución de Gómez Moreno al obispo Poncio de Oviedo ${ }^{75}$, con la que encuentran fácil explicación las formas asturianas que la caracterizan.

San Juan de la Peña, cuarta gran iglesia relacionada por algunos autores con Sancho el Mayor, resulta enormemente problemática debido a las sucesivas remodelaciones y reparación de daños causados por incendios. Uranga e Íñiguez le atribuyeron "la prolongación de nave única (...), a más de la sala llamada del concilio", empresas constructivas que serían coetáneas de una reforma institucional del cenobio $^{76}$. Debo reconocer que todavía no he alcanzado una opinión formada capaz de integrar adecuadamente tanto las referencias documentales (las controvertidas de tiempos de Sancho el Mayor y las dos consagraciones de las que hay noticia, 1080 y 1094, que habrían culminado campañas arquitectónicas desarrolladas durante el reinado de Sancho Ramírez) como las evidencias materiales. Confío en que el proyecto de investigación actualmente en curso incremente el conocimiento de este edificio ${ }^{77}$.

Apenas conservamos construcciones directamente vinculadas a García Sánchez III el de Nájera ${ }^{78}$. Durante su vida avanzaron las obras de Leire, iniciadas por su padre. Han llegado a nuestros días escasos vestigios del edificio románico de Santa María la Real de Nájera, que fundó en 1052 (un fragmento del muro meridional con ventana y canecillos, un capitel trasladado a Jaca y algunos elementos esculpidos), lo que no basta para hacernos una idea $\mathrm{cabal}^{79}$. Por lo que respecta a su hijo, Sancho IV el de Peñalén participó siendo niño en la consagración de la iglesia de

74 P. Gonzalo Martínez, "Restauración y límites de la diócesis palentina", Publicaciones de la Institución Tello Téllez de Meneses, 59 (1988), p. 359.

75 Gómez Moreno, El arte románico, p. 53: "agrandó la cripta goda de su catedral”.

76 Uranga e ÍñIguez, Arte medieval, I, p. 220. Fuentes antiguas del propio cenobio (Briz Martínez, 1620) habían atribuido de manera legendaria la construcción de la Sala del Concilio al rey García Ximénez. Con posterioridad ha sido relacionada con "la ampliación del monasterio prerrománico efectuada durante el reinado de Sancho Ramírez", con destino a sala capitular o a dormitorio común: M.C. LACARRA y J.L. GARCíA Lloret, "Arte en el monasterio medieval de San Juan de la Peña", San Juan de la Peña (suma de estudios, I), Zaragoza, 2000, p. 54.

77 Véase nota 1.

78 J. Martínez de Aguirre, "Manifestaciones artísticas en Navarra durante el siglo XI", García Sánchez III "el de Nájera”. Un rey y un reino en la Europa del siglo XI, Logroño, 2005, pp. 367-398.

79 Sobre las iglesias riojanas: M. SÁENZ RodRíGUEZ, "El primer románico en La Rioja durante el esplendor del reino de Nájera-Pamplona (1000-1076)", García Sánchez III “el de Nájera”. Un rey y un reino en la Europa del siglo XI, Logroño, 2005, pp. 399-452. Sobre Nájera: J.L. SEnRa Gabriel y GaLÁn, “Algunas notas sobre la realidad románica del priorato cluniacense de Santa María de Nájera en su contexto histórico", Memoria Artis. Studia in memoriam Ma Dolores Vila Jato, Santiago de Compostela, 2003, pp. 123-141; para lo que aquí nos interesa, atribuye el capitel hoy en Jaca no a la construcción de García Sánchez III, sino a una ampliación posterior a su entrega a Cluny (1079) y lo data hacia 1100. Véase también la voz "Nájera" en la Enciclopedia del Románico en La Rioja, Aguilar de Campoo, 2008. 
Leire (1057) y diez años más tarde en la de San Millán de la Cogolla de Yuso (cuyas cimentaciones han aparecido en excavaciones recientes y están publicadas sólo parcialmente; se han identificado los tres ábsides semicirculares escalonados y los muros de las naves ${ }^{80}$ ). Quizá colaboró en San Miguel de Aralar, edificio insuficientemente conocido, en la fase que culminó con la consagración de $1074^{81}$.

En resumen, ni las actuaciones de los gobernantes en el ámbito aragonés, ni la política constructiva de los dos monarcas navarros previos a Sancho Ramírez proporcionaban un modelo de actuación en el terreno arquitectónico que fuera más allá de la fortificación de la frontera, en ocasiones ostentosa (Loarre), y de la previsible colaboración en iglesias incardinadas en tradiciones locales o receptoras de fórmulas procedentes de territorios vecinos. Sólo la actuación de Sancho III ofrecía, a través de la obra de Leire, un paradigma de construcción ambiciosa y renovadora, la consecución de un reto constructivo derivado de nuevas circunstancias, donde coincidía la reorganización de la sede diocesana con el papel que con respecto a dicha sede y a la monarquía jugaba el monasterio, vinculado desde hacía décadas con la familia regia. Será preciso explorar en qué medida el modelo de actuación de su abuelo paterno fue o no determinante a la hora de que Sancho Ramírez diseñara una política constructiva propia.

\section{Sancho Ramírez: el rey y su reino}

La posibilidad de comprender mejor las iniciativas e incluso las peculiaridades de ciertos encargos arquitectónicos de Sancho Ramírez a la luz de su ejercicio de la realeza hace necesario examinar siquiera brevemente determinados vectores de actuación en lo que se refiere a su concepto de monarquía, su acceso al trono de Pamplona, su política religiosa, su enfrentamiento con los andalusíes y sus relaciones con Castilla ${ }^{82}$.

${ }^{80}$ El hallazgo inicial del ábside meridional se produjo en las excavaciones del claustro de 2001: J.A. Tirado Martínez, "Seguimiento arqueológico en el patio y los pasillos del claustro de Yuso", Estrato. Revista Riojana de Arqueología, 13 (2001), pp. 105-113. Fue descubierta en la galería septentrional "una estructura absidal próxima a la puerta de acceso a la iglesia" de algo más de dos metros de anchura, además de varios elementos arquitectónicos románicos. Sobre todo ello, también puede verse la voz "San Millán de Yuso" de la Enciclopedia del Románico en La Rioja, Aguilar de Campoo, 2008.

${ }^{81}$ C. Fernández-Ladreda (dir.), J. Martínez de Aguirre y C.J. Martínez Álava, El arte románico en Navarra, Pamplona, 2002, pp. 70-73.

$\underline{82}$ El reinado de Sancho Ramírez cuenta con amplísima bibliografía, entre la que señalaremos: A. UBIETO Arteta, Colección diplomática de Pedro I de Aragón y de Navarra, Zaragoza, 1991; ID., Historia de Aragón I. La formación territorial, Zaragoza, 1981 (en adelante citado: Ubieto, Historia); D. Buesa Conde, Sancho Ramírez, rey de aragoneses y pamploneses, Zaragoza, 1996; C. Laliena, La formación del estado feudal. Aragón y Navarra en la época de Pedro I, Huesca, 1996 (en adelante citado: LaLIENA, Formación); E. SARASA (coord.), Sancho Ramírez, rey de Aragón, y su tiempo. 1064-1094, Huesca, 1994; A.I. LaPeÑa Paúl, Sancho Ramírez Rey de Aragón (;1064?-1094) y rey de Navarra (1076-1094), Gijón, 2004. La documentación del 
Hacia 1030 Sancho el Mayor puso a Ramiro, su hijo primogénito y extramatrimonial, al frente de Aragón, territorio con personalidad propia integrado en el reino de Pamplona desde la primera mitad del siglo X. La asociación de los hijos al gobierno de un territorio era práctica común en la época, tendente a hacer presente la potestas regia en todos sus dominios, a consolidar el linaje y a proporcionar experiencias de gobierno a los posibles herederos. Un precioso testimonio, probablemente de 1035, nos presenta a Ramiro como destinatario de la 'tierra' de su padre que se extendía entre Matidero y Vadoluengo (con excepción de Loarre, San Emeterio, Ruesta y Pitilla), donación que está en el origen del reino de Aragón: dono de terra mea... tota illa terra que teneas, abeas, possideas illa per secula cuncta... ab omni integritate tam populatum quam etiam pro populare ${ }^{83}$. Como interpreta Martín Duque, Sancho III transfirió a su hijo "una porción no de su reino, sino de su tierra, es decir, de las correspondientes honores con sus emolumentos" ${ }^{\prime 4}$. Ramiro la recibió al tiempo que juró a su hermano García, el mayor entre la prole legítima, que no requeriría otra tierra ni le atacaría, y que sería enemigo de quienes le agredieran, en lo que constituye una clara disposición feudovasallática ${ }^{85}$. Años después, en uno de los enfrentamientos fratricidas que tan habituales fueron en el linaje pamplonés, García murió en combate contra las tropas de su hermano Fernando I (batalla de Atapuerca, 1054) y le sucedió Sancho IV, que todavía no había alcanzado la mayoría de edad. Con él, que era su sobrino, Ramiro I renovaría pacto feudal ofreciéndole "amistad, fidelidad, ayuda y consejo" y recibiendo como contraprestación el castillo de Sangüesa y las villas de Lerda y Undués ${ }^{86}$. Se aprecia, por tanto, una posición de subordinación de Ramiro con respecto a los sucesivos monarcas pamploneses.

Terra y no regnum es el término asimismo utilizado por Ramiro I en su testamento para referirse a sus dominios, lo que lleva a cuestionar la naturaleza del poder que ejercía y su concepto de realeza. El asunto fue estudiado por Antonio Ubieto a partir de las cláusulas de intitulación empleadas por la cancillería ramirense ${ }^{87}$. Los documentos de particulares y los diplomas regios pamploneses y castellanos coetáneos califican a Ramiro de rex; sin embargo, el propio Ramiro nunca enca-

monarca ha sido publicada por Salarrullana, Documentos; E. IBARRA, Documentos correspondientes al reinado de Sancho Ramírez desde 1063 hasta 1094. Documentos particulares, Zaragoza, 1913 (en adelante citado: Ibarra, Documentos); y A. Canellas, Colección diplomática de Sancho Ramírez, Zaragoza, 1993 (en adelante citado: CANELlas, Colección).

83 R. Jimeno Aranguren y A. Pescador Medrano, Colección documental de Sancho Garcés III, el Mayor, rey de Pamplona (1004-1035), Pamplona, 2003, doc. 78, pp. 267-268.

${ }^{84}$ A. Martín Duque, Sancho III el Mayor de Pamplona. El rey y su reino (1004-1035), Pamplona, 2007, p. 347.

${ }^{85}$ Al respecto, LaLiena, Formación, p. 56 y passim.

${ }^{86}$ J.M. Lacarra, Historia política del reino de Navarra, Pamplona, 1973, vol. I, p. 256 (en adelante citado: LACARRA, Historia).

87 A. Ubieto Arteta, Orígenes de los reinos de Castilla y Aragón, Zaragoza, 1991, especialmente el epígrafe "Ramiro I y su concepto de la realeza", pp. 127-134. 
bezó sus diplomas como Dei gratia rex, al contrario de lo que venían haciendo los monarcas de Pamplona. Todos los documentos originales que emitió entre 1043 y 1064 emplearon como fórmula más frecuente Ego Ranimirus, Sancioni regis filius (o prolis $)^{88}$. De ello dedujo Ubieto que Ramiro no se consideraba con respecto a la realeza del mismo modo que los soberanos pamploneses ${ }^{89}$.

La revisión de la documentación condujo al mismo historiador a afirmar que tampoco Sancho Ramírez se tituló Gratia Dei rex en ningún documento original y auténtico anterior a 1076, es decir, antes del año en que accedió al trono pamplonés. No obstante, en su actuación no mantuvo una situación de subordinación con respecto a Sancho IV el de Peñalén semejante a la de su padre. Quienes se han ocupado del asunto vienen afirmando que uno de los logros del viaje de Sancho Ramírez a Roma en 1068 consistió en obviar la dependencia con respecto a la monarquía pamplonesa, mediante la infeudación a la Santa Sede. Como otros magnates europeos de su tiempo, el aragonés buscó en Roma la vinculación externa prestigiosa que avalara el nuevo reino ${ }^{90}$. La información de que disponemos es escasa y tardía, lo que ha alentado especulaciones en diversas direcciones. No fue el primer miembro del linaje regio pamplonés en emprender una visita a la sede pontificia, puesto que ya su tío García el de Nájera lo había hecho como "piadosa peregrinación a las tumbas de los Apóstoles y una visita de devoción cristiana al papa" ". La actuación posterior de Sancho Ramírez evidencia que, en su caso, más allá de preocupaciones personales de carácter religioso o familiar, el viaje tuvo una dimensión política ${ }^{92}$. Un diploma de 1088-1089 recuerda que veinte años atrás se entregó junto con su reino (meque regnumque meum in Dei et eius potestate tradidi ${ }^{93}$ ), quizá aceptando las teorías acerca de la supremacía

${ }^{88}$ En su opinión los documentos con la expresión Ego Ranimirus, Dei gratia rex o similares, o bien son falsos, o bien corresponden a copias muy tardías procedentes de San Juan de la Peña o de San Victorián, por lo que han de atribuirse "a interpolaciones y no al formulario utilizado por la cancillería ramirense". Otras intitulaciones que incluyen la palabra rex aparecen en textos falsos, interpolados o de autenticidad no segura. Ubieto explica las diferencias constatables en buen número de casos entre la intitulación, que se redacta al principio del documento, y la cláusula "regnante", ubicada al final del mismo y donde con frecuencia sí aparece el término rex, con el siguiente argumento: "esta cláusula la redacta el escriba por su cuenta, prescindiendo de lo que el monarca ha hecho anteriormente", puesto que alude al monarca en tercera persona; incluso a veces incurren en incorrecciones inexplicables en caso de que las hubiera dictado el propio monarca. A. IsLA Frez, Realezas hispánicas del año mil, Sada, 1998, p. 143, n. 66, considera este planteamiento "muy discutible".

89 Sobre la cuestión, han de verse también las consideraciones de LALIENA, Formación, p. 71, que matiza el alcance de las intitulaciones a la hora de valorar la naturaleza de la realeza, ya que en su opinión sería "aventurado deducir que ello circunscribía su poder".

90 L. García-Guijarro Ramos, "El papado y el reino de Aragón en la segunda mitad del siglo XI", Aragón en la Edad Media, XVIII (2004), pp. 247-248.

91 P. KeHr, "Cómo y cuándo se hizo Aragón feudatario de la Santa Sede", Estudios de Edad Media de la Corona de Aragón, I (1945), p. 288 (en adelante citado: KeHr, “Cómo y cuándo”).

92 Se han barajado motivaciones personales que no es posible confirmar, relacionadas con su matrimonio con Isabel de Urgel. Recalca su carácter de "sólo un acto de devoción y de entrega completamente personal": P. KeHr, "El Papado y los reinos de Navarra y Aragón hasta mediados del siglo XII", Estudios de Edad Media de la Corona de Aragón. Sección de Zaragoza, II, Zaragoza, 1946, p. 94 (en adelante citado: KeHR, "Papado”).

93 Kenr, "Cómo y cuándo", doc. III, p. 319. 
del papado que con tanta claridad expondría años después una carta enviada por Gregorio VII a nobles franceses dispuestos a participar en una campaña en la península: "No se os oculta que el reino de España fue desde antiguo de la jurisdicción propia de san Pedro, y aunque ocupado tanto tiempo por los paganos, pertenece todavía por ley de justicia a la Sede Apostólica solamente"94.

El nuevo rumbo asumido por la monarquía aragonesa con Sancho Ramírez se acusa en el nombre escogido para el primogénito, probablemente nacido ese mismo año de 1068 o en 1069: Pedro, príncipe de los apóstoles, lo que supone una ruptura con tradiciones propias de su linaje y manifiesta toda una toma de posición. Mientras Ramiro I había elegido para sus hijos varones nombres característicamente pamploneses (Sancho y García), Sancho Ramírez da entrada a uno del que no hay antecedentes en las casas regias pamplonesa y leonesa. El alejamiento con respecto a Pamplona fue en aumento. Del "consejo y auxilio" que habían presidido las relaciones entre Ramiro y Sancho IV se pasó en pocos años a la posibilidad de enfrentamientos directos, como prueba el texto del tratado firmado entre el de Peñalén y Muqtadir de Zaragoza en $1073^{95}$.

Sancho Ramírez había viajado a Roma poco después de que un ejército compuesto por guerreros ultrapirenaicos y catalanes hubiese tomado Barbastro (1064), conquista que por una parte demostró la posibilidad de ocupar una gran población musulmana y por otra abrió las tierras hispanas a la participación de contingentes procedentes de distintos lugares de Europa dispuestos a emprender campañas que les rindieran beneficios en tierras o en botín, y les ayudaran a ganar el cielo. Pero la inmediata recuperación de la localidad por las tropas de Muqtadir mostró igualmente que el enemigo no iba a ceder sin más sus poblaciones prósperas al avance cristiano.

El vínculo romano y la legación del cardenal Hugo Cándido fructificaron en la introducción en Aragón del rito promovido por la Santa Sede en sustitución del antiguo rito hispano ${ }^{96}$. Su recepción en la abadía de San Juan de la Peña se revistió de connotaciones cósmicas, ya que se esperó al equinoccio de primavera de 1071, al momento en que el sol alcanzó su cénit entre las horas tercia y sexta, para que la comunidad monástica dejase de seguir la lex toletana y aceptase la reforma auspiciada por el papado (lex romana). El cambio representa la primera acción de

94 A. Ubieto Arteta, Los orígenes de los reinos de Castilla y Aragón, Zaragoza, 1991, pp. 174-175; Ubieto, Historia, p. 81.

95 “Conviene el rey don Sancho a al-Muqtadir billáh, si él este predicho pacto observare rectamente sin ningún engaño, que procurará enviar embajadores a Sancho Ramírez para que él y los suyos hagan dejar la tierra de Huesca y se vuelva a la suya, y que no hagan ningún daño en partes de Zaragoza. Y si no quisiese marchar Sancho Ramírez de las tierras de al-Muqtadir, al punto cabalgue con todo su poder el dicho rey Sancho contra Sancho Ramírez para hacerle daño en su tierra": UBIETo, Historia, p. 79. J.M. LACARRA profundizó en la importancia de este tratado, renovador de uno anterior que igualmente proporcionaba pingües ingresos al monarca pamplonés: "Dos tratados de paz y alianza entre Sancho el de Peñalén y Muqtadir de Zaragoza (1069 y 1073), Estudios de historia navarra, Pamplona, 1971, pp. 83-102.

96 A. Ubieto Arteta, "La introducción del rito romano en Aragón y Navarra", Hispania Sacra, 1 (1948), pp. 299-324. 
calado de una nueva política religiosa favorable a la reforma, que transformaría mediante sucesivas actuaciones las estructuras eclesiásticas tradicionales y también las relaciones entre el monarca y los prelados de su reino, hasta entonces regidas por costumbres hispanas. Pero la independencia de los obispados y la libertad de los monasterios podían comportar consecuencias negativas para el monarca, especialmente en lo referente al control de las rentas y de la voluntad de los prelados ${ }^{97}$. Aragón era un reino volcado en la conquista de territorios andalusíes, para lo que necesitaban huestes de muy caro mantenimiento. Sancho Ramírez se las ingenió para mantener una serie de instituciones religiosas de primer nivel bajo su directo control. Desde esta perspectiva hay que contemplar la fundación del monasterium Sancti Petri de castello Luar frente a la fortaleza de Bolea (recibido bajo tutela papal en 1071, según un privilegio de veracidad discutida ${ }^{98}$; la donación a Montearagón de 1093 lo denomina capellam Sancti Saluatoris de Luar ${ }^{99}$ ), la constitución de capillas regias en Siresa y Alquézar, entre otras, y, como centro de mayor significación, la creación de la canónica de Jesús Nazareno de Montearagón, alojada en el castillo homónimo ${ }^{100}$, enclave estratégico fundamental para cortar las comunicaciones de Huesca con Barbastro, Monzón y Lérida.

Desde el punto de vista de las grandes realizaciones constructivas, el viaje a Roma de 1068 parece haber tenido menor impacto inmediato que los acontecimientos desencadenados tras el magnicidio de Peñalén en 1076. Recordemos brevemente lo sucedido ${ }^{101}$. Sancho IV de Pamplona había acometido una política con respecto a Al Andalus caracterizada por los acuerdos con Muqtadir de Zaragoza, a cambio de sustanciosas parias (12.000 mancusos anuales). Al parecer el soberano no distribuyó parte de los ingresos entre sus barones y cometió ciertos abusos que propiciaron un complot culminado en su asesinato el 4 de junio de 1076. La colaboración de sus hermanos en la conjura los desautorizó para la sucesión y sus hijos eran todavía muy pequeños, por lo que se produjo un vacío de poder aprovechado por Sancho Ramírez, desde Aragón, y Alfonso VI, desde Castilla, para ocupar el reino pamplonés. Sancho se apropió del espacio nuclear hasta el Ebro; Alfonso, de

97 El derecho eclesiástico de la España de entonces atribuía a los reyes, magnates y obispos la facultad de disponer de las iglesias: KeHR, "Papado", p. 88.

98 Lo publicó como auténtico P. KeHR, Papsturkunden in Spanien. Vorarbeiten zur Hispania pontificia II: Navarra und Aragon, Berlín, 1928, doc. 3, pp. 260-262 (en adelante citado: KeHr, Papsturkunden). A. Durán Gudiol, La Iglesia de Aragón durante los reinados de Sancho Ramírez y Pedro I (1062?-1104), Roma, 1962 , p. 28, inicialmente lo consideró "una manifiesta falsificación”. Más tarde matizó su punto de vista: "no es seguro que el documento, tal como nos ha llegado, sea falso, pero sí parece claro que se trata de un diploma adulterado por los canónigos montearagoneses (...). Su testimonio es sustancialmente válido: ID., El castillo de Loarre, Huesca, 1971, p. 12.

99 M.D. Barrios Martínez, Documentos de Montearagón (1058-1205), Huesca, 2004, doc. 6, p. 30.

100 Montearagón recibirá bienes de otras instituciones que previamente habían sido utilizadas por el rey en su propio interés, como Santa María de Ujué y Santiago de Funes, ésta última destinada inicialmente a constituirse en punto fuerte de la reconquista en las tierras meridionales navarras (donación de 1086).

101 Sobre estos acontecimientos: LACARRA, Historia, I, pp. 256-278. 
las tierras riojanas hasta el mismo río. No hubo enfrentamiento bélico entre ambos primos. El acuerdo definitivo sobre el reparto se firmaría años después; por él, Sancho prestaría vasallaje a Alfonso por el condado de Navarra ("Pamplona, Aibar, Tafalla, Falces, Leguín, Monjardín y quizás, Erro"102), lo que consolidaba las aspiraciones imperiales del castellano. El reino de Pamplona significó para el aragonés no sólo una ampliación en tierras, población y rentas, que aumentaron los recursos materiales y humanos dedicados a las conquistas, sino también y muy especialmente la soberanía indiscutida. Con el acceso de Sancho al trono pamplonés desapareció la dependencia de iure de una potestas superior, con lo que pasó a titularse con total propiedad rex gratia Dei aragonensium et pampilonensium.

Los documentos manifiestan que el soberano reafirma a partir de entonces su incardinación en el tronco de los reyes pamploneses. En sus diplomas una y otra vez se acuerda de la gran figura del linaje, su abuelo Sancho el Mayor. En la donación de Úcar a San Juan de la Peña de 1077 hace memoria de su digno recuerdo (Digne namque recordationis Sancius rex, auus meus) insistiendo en que había expulsado a los musulmanes de sus tierras (deuictis atque expulsis Ismaelitarum gentibus a regni sui finibus) y que con él compartía un antiguo linaje de antepasados (monasterio supradicto Sancti Iohannis Babtiste, in quo humata sunt auorum ac proauorum suorum meorumque corpora $)^{103}$. Ramírez no tiene ninguna duda de que está viviendo en lo más alto de su poder (ego Sancius, rex, tenens culmen potestatis mee in Pampilona et in Aragona, in Suprarbi et in Ripacorça $\left.{ }^{104}\right)$. Estoy persuadido de que la proliferación de referencias a su abuelo refleja una asunción de su figura como modelo. Sancho el Mayor era paradigma no sólo de rey guerrero, vertiente que indudablemente desarrollará Ramírez con mayor ímpetu a partir de este momento, sino también de rey sabio y justo, piadoso y protector de instituciones religiosas (reconocida por el propio abad Oliba). Estas cualidades encarnaban el ideal medieval de la realeza, que se miraba en los espejos de David y Salomón.

Resultan clarificadoras las referencias que de Sancho el Mayor incluye la Crónica de San Juan de la Peña, donde la narración de sus gestas se abre con su papel como legislador: "el qual fizo y ordenó los buenos fueros, porque entro a las oras todo lo que se fazia en la tierra se judgava a arbitrio de los presidentes en aquella"105. No pa-

102 Ibídem, p. 275.

103 Salarrullana, Documentos, XIV. En la donación de Santiago de Aibar (1080) se remonta nada menos que a su tatarabuelo Sancho Abarca (de illo monasterio, qui uocitatur Sanctus Iacobus de Aiuar, quod dedit tritaux meus Sancius, cognomento Auarca: Ibíd., XVII). En este diploma se acuerda de nuevo de su abuelo Sancho el Mayor (et Sancius rex, auus meus, quando Ordinem et regulam Beati Benedicti in Sancto Iohanne constituit). En la misma línea, la confirmación de la donación de los términos de Fuenfría (1088): Ita ut dederunt ei antecessores mei reges, ego similiter do et confirmo (Ibid., XXXVI).

104 Salarrullana, Documentos, XV (1077). La misma expresión en XXIX (1086): Ego Sancius, gratia Dei rex, tenens culmen potestatis mee in Aragona et in Pampilona.

105 C. Orcástegui Gros, Crónica de San Juan de la Peña. (Versión aragonesa). Edición crítica, Zaragoza, 1986, p. 28. 
rece casual que una de las primeras actuaciones de Sancho Ramírez, recién alcanzada la soberanía, consistiese en conceder fuero a Jaca, es decir, en el ejercicio de la prerrogativa de creación de un nuevo marco jurídico concerniente a la que iba a ser capital de su reino ${ }^{106}$. La decisión de convertirla en civitas, establecer allí la sede episcopal y dotar a sus habitantes de privilegios no sólo dignificaba el nuevo reino aragonés y compensaba la pérdida de Nájera, sino que lo asemejaba a su abuelo y evidenciaba su condición de rex a través del ejercicio de su capacidad de dictar normas de derecho en la línea de lo que habían hecho los monarcas visigodos con los que los pamploneses habían pretendido enlazar ${ }^{107}$. Pronto veremos el reflejo de esta dimensión de legislador en sus empresas arquitectónicas, materializada en la catedral de Jaca.

Las relaciones con Alfonso VI fueron cambiando a lo largo de los años. El acercamiento a Castilla paralelo al alejamiento de Pamplona vivido antes de 1076 había condicionado la elección de los nombres de los hijos de Sancho y su esposa Felicia de Roucy. Al primogénito del matrimonio, nacido probablemente en 1071, lo llamaron Fernando, como el padre de Alfonso VI, espejo de monarcas, y al segundo directamente Alfonso, de resonancias leonesas ${ }^{108}$. Sólo a su hijo menor, nacido quizá en 1087, lo bautizaron con el nombre del progenitor del monarca, Ramiro. La onomástica más habitual en la monarquía navarra (Sancho y García) fue descartada para la prole regia. Frente a estas buenas relaciones con Castilla previas a 1076, a partir de ese año, una vez que la dignidad regia de Sancho Ramírez está fuera de toda duda y su poder político, económico y militar se multiplica, el aragonés y el castellano pasaron a ser competidores.

Su nueva condición soberana dio alas a sus ambiciones militares y le hizo ver de otro modo la potestas de su primo Alfonso. Amancio Isla recuerda que un documento de 1077 insiste en el concepto de que Alfonso VI era rex in Spania, "lo que no se opone a que el escriba añada a renglón seguido que Sancho Ramírez es ahora rey en Pamplona y Aragón"109. El soberano aragonés hubo de reflexionar y trazar una línea de actuación propia con respecto a las aspiraciones del imperium leonés

106 No se puede deslindar esta actuación de la inclusión de Nájera bajo dominio de Alfonso VI, que había implicado la pérdida de la que había sido principal sede regia de los monarcas pamploneses en las últimas décadas, al mismo tiempo sede episcopal y centro urbano dinámico, y cuyos habitantes contaban con privilegios concedidos por Sancho el Mayor.

107 Recordemos al respecto la conocida miniatura del Códice Albeldense encabezada por los tres reyes legisladores Recesvinto, Chindasvinto y Egica, acompañados de los monarcas pamploneses Sancho Garcés II Abarca, su esposa Urraca y su hermano Ramiro, que aparecen vinculados visualmente con sus antepasados godos: J. Martínez de Aguirre, "Creación de imágenes al servicio de la monarquía”, Signos de identidad histórica para Navarra, Pamplona, 1996, vol. I, pp. 192-195. El Albeldense y el Emilianense, códices probablemente utilizados en la formación intelectual de Sancho III el Mayor, contienen la Lex Canonica Hispana, es decir, la ley religiosa por la que se regía la iglesia hispana, y la Lex Iudiciorum o Fuero Juzgo, que imperaba en los asuntos civiles.

108 LaLiena, Formación, p. 105 interpreta esta elección como "signo de buenas relaciones arbitradas en el transcurso de 1073 entre Alfonso y Sancho contra el rey de Navarra y su aliado al-Muqtadir de Zaragoza”.

109 A. Isla Frez, Memoria, culto y monarquía hispánica entre los siglos X y XII, Jaén, 2006, p. 147. Dedica el capítulo V a "El imperium de Alfonso VI. Tradición e innovación”: pp. 131-184 (en adelante: IsLA, Memoria). 
de Alfonso por una parte y a las pretensiones papales sustentadas en la supuesta donación de Constantino por otra.

En lo que respecta a la conquista de tierras andalusíes, tras un período de calma, quizá motivado por la reorganización del reino, Sancho diseñó una nueva estrategia consistente en la toma de castillos de gran valor territorial y la construcción de otros en puestos avanzados y nudos de comunicación. La toma de Castro Muñones, recordada en varios diplomas ${ }^{110}$, fue seguida por concesiones de edificación de torres que comentaremos en su momento. La muerte de Muqtadir en 1081-1082 condujo al fraccionamiento del reino taifa entre hijos rivales y dio nuevo impulso al aragonés. La conquista de Graus en 1083 se acompañó de un componente simbólico, ya que era el lugar donde había encontrado la muerte Ramiro I; poco después sus restos mortales fueron trasladados a un nuevo sepulcro en San Juan de la Peña. Le siguieron la conquista de Naval y Arguedas (1084) y la preparación del terreno para grandes objetivos: Huesca y Zaragoza.

1085 vino marcado por dos acontecimientos de honda repercusión: la muerte de Gregorio VII y la conquista de Toledo por Alfonso VI. Los papas sucesores, Víctor III y Urbano II (promotor de la primera cruzada), no insistieron en las aspiraciones de supremacía de su antecesor con respecto a la península. Si a esto unimos el desequilibrio en el poder político y en el terreno simbólico que había supuesto la conquista de la capital visigoda, entenderemos que Sancho Ramírez se decidiera a incrementar la relación privilegiada con el papado. Avizora la conquista de Huesca, pero advierte el peligro de que Alfonso se adelante con la toma de Zaragoza, a la que el castellano se acerca en campaña en 1086, interrumpida por el desembarco de los almorávides. La derrota de Zalaca en octubre de ese año refrenará las aspiraciones de Alfonso. En 1087 un contingente militar ultrapirenaico acude a la península en ayuda del castellano para recuperar lo perdido el año anterior y de regreso pone cerco a Tudela sin conseguir su rendición. El mismo año el rey Alfonso se intitularía: Ego namque Adefonsus, ab ipso Deo constitutus imperator super omnes Spanie nationes ${ }^{111}$. Y en 1088 Alfonso concedió a San Pedro de Roma la iglesia de San Servando de Toledo, encabezando el diploma con una intitulación semejante ${ }^{112}$. Es en estas circunstancias cuando Sancho recupera el vínculo feudovasallático con respecto a San Pedro y no sólo promete, sino que paga la considerable cantidad de 500 mancusos de oro anuales ${ }^{113}$. Es un paso más en una actuación dirigida a la conquista de Huesca, a la que dedicará todos sus esfuerzos en los años venideros.

110 Castro Muñones estaba en poder cristiano con seguridad en primavera de 1081. Existen dudas acerca de diplomas que atestiguan una conquista anterior, algunos de ellos falsificados: J.A. AsEnsio EsTEBAN et alii, "La fortaleza andalusí del Cerro Calvario (La Puebla de Castro, Huesca). Propuesta de identificación de la misma con Castro Muñones", Aragón en la Edad Media, XX (2008), pp. 85-102.

111 A. Gambra, Alfonso VI. Cancillería, curia e imperio. II Colección Diplomática, León, 1998, doc. 89.

112 Isla, Memoria, p. 160.

113 KeHr, "Cómo y cuándo", docs. III y IV. 
Llega el momento de trasladar todas estas circunstancias al campo arquitectónico. Sancho Ramírez, en su nueva situación a partir de 1076, soberano indiscutible de iure y poderoso de facto, se siente "en el culmen de su poder". Es un hecho que va a desarrollar una arquitectura nueva, caracterizada por recursos muy distintos a lo hasta entonces realizado no sólo en Aragón, sino en el resto de los reinos cristianos peninsulares. Cabe especular acerca de si los modelos "condales" ("primer románico meridional" en términos histórico-artísticos), que habían sido referencia décadas atrás, a los ojos del nuevo soberano ya no ofrecerían suficiente prestigio como paradigmas desde el punto de vista de sus connotaciones simbólicas. Tampoco las creaciones castellanas previas, que por su parte vivían una rápida transformación, aparecen como las más adecuadas para su importación con vistas a la monumentalización del reino. Sólo las grandes empresas de los años setenta, y muy concretamente la catedral compostelana, mostraban un paradigma digno de imitación. En Santiago se había emprendido en un edificio que superaba en dimensiones y ambición arquitectónica todo lo hasta entonces ensayado, y que acomodaba las fórmulas desarrolladas en tierras francesas a las aspiraciones propias de una "sede apostólica". Pero las obras sufrieron interrupciones. En la misma línea, la arquitectura de Jaca y Loarre ofrecerá una imagen nueva del poder del naciente reino donde se hermanarán las preocupaciones religiosas y la vocación conquistadora. Sus referentes formales e iconográficos se encuentran en edificaciones como San Pedro del Vaticano y Saint-Sernin de Toulouse, sin olvidar el impacto de experiencias artísticas inmediatas vividas por sus creadores, como el conocimiento del sarcófago de Husillos o los primeros pasos de Frómista. La genialidad del arte aragonés de estas fechas radica justamente en la combinación de novedades programáticas de gran ambición (en las que se manifiesta la voluntad regia) con prácticas incardinadas en las creaciones más recientes y prestigiosas al alcance de artistas de indudable capacidad y mérito.

\section{La catedral de Jaca y la imagen del soberano}

De los treinta años de reinado de Sancho Ramírez, durante los doce primeros no hay constancia de encargos arquitectónicos relevantes ${ }^{114}$. Las cosas cambiaron a partir de 1076. La nueva situación derivada del acceso al trono pamplonés vino seguida de actuaciones de profundísimas consecuencias cuya vertiente arquitectónica merece ser explorada, puesto que propiciaron la introducción de una nueva manera

114 Salvo el discutible alcance y verosimilitud de la afirmación contenida en la bula papal de tutela de Loarre (1071), cuando asevera que el monasterio de San Pedro del castillo de Loarre había sido construido por el rey (ab eo constructum et edificatum): KeHr, Papsturkunden, p. 251. Sobre la veracidad del contenido de esta bula, véase nota 97. 
de construir y de aprovechar la arquitectura tanto para el fortalecimiento de la monarquía como en la imagen que de sí misma transmitió a sus contemporáneos (y hasta nuestros días). Cabe contemplar estas actuaciones como parte de los mecanismos que permitieron a Sancho Ramírez adoptar una apariencia soberana y favorecieron el enriquecimiento de su carisma ${ }^{115}$. Por otra parte, estas obras resultaron de gran significación para el arte románico aragonés y peninsular. Examinaremos primero las empresas religiosas y luego comentaremos ciertos aspectos de las fortificaciones.

El principal edificio que centrará nuestra atención es la catedral de Jaca, de ambición arquitectónica muy superior a todo lo hasta entonces realizado en Aragón. Como hemos visto, antes de 1958 los historiadores hacían descansar la datación del templo en tiempos de Ramiro I sobre tres diplomas, cuya coincidencia proporcionaba certidumbre. Fue mérito de Antonio Ubieto Arteta advertir su falsedad y proponer una fecha alternativa para el inicio del templo catedralicio, que en su opinión no podía ser anterior a 1077, año en que el rey otorgó la condición de ciudad a Jaca, lo que permitía que fuera sede episcopal de acuerdo con la normativa canónica. Ciertamente el argumento no es irrebatible, en la medida en que un gran empeño arquitectónico pudo haber sido iniciado en Jaca antes de que se estableciera allí la sede conforme a los cánones. Es un hecho la existencia de un edificio previo, San Pedro el Viejo, de cuyas cimentaciones ya hemos dado cuenta. Con el mismo criterio con el que los obispos aragoneses estuvieron establecidos durante un tiempo en Sasave, iglesia que había sido sede y panteón episcopal no permanente en los siglos X y XI, bien podrían haber trasladado su residencia principal a la villa de Jaca y haber principiado una nueva iglesia. Para todo ello no era necesario que Jaca fuera ciuitas, pero sí para establecer una sede episcopal conforme a las normas de la iglesia reformista. Ahora bien, el respeto a los cánones fue selectivo por parte de nuestro monarca. Ramiro I o Sancho Ramírez pudieron haber pensado en dotar con una sede de mayor monumentalidad al obispado de Aragón, que hasta entonces no había estado establecido en templos de grandes dimensiones. En resumen, el argumento de Ubieto por sí solo es insuficiente a la hora de fechar el inicio de la renovación de San Pedro de Jaca. Hemos de contrastar otros razonamientos para llegar a una conclusión que aspire a definitiva.

¿En qué momento fue tomada la decisión de sustituir el antiguo templo de San Pedro el Viejo por un edificio mucho más monumental, dotado de tres ábsides escalonados de considerables dimensiones, vinculado a una reurbanización en su entorno? ${ }^{116}$ ¿Se hizo a iniciativa del monarca? Carecemos de documentación que

115 Sobre las políticas de carisma de la monarquía hispana en el siglo XI: C. LALIENA, "Encrucijadas ideológicas. Conquista feudal, cruzada y reforma de la Iglesia en el siglo XI hispánico", La reforma gregoriana y su proyección en la cristiandad occidental. Siglos XI-XII, Pamplona, 2006, pp. 289-333 (en adelante citado: LALIENA, "Encrucijadas").

116 Sobre el desarrollo urbano de Jaca en el siglo XI: L.H. NeLson, "The Foundation of Jaca (1076): Urban Growth in Early Aragon", Speculum, LIII (1978), pp. 688-708; J. PAssinI, "La structure urbaine de Jaca aux XI ${ }^{\mathrm{e}}$ et XII ${ }^{\mathrm{e}}$ siècles”, Mélanges de la Casa de Velázquez, XXIV (1988), pp. 71-97. Recientes excavaciones 
relacione directamente a Sancho Ramírez con el pago de las obras de la catedral, que quizá no dejó huella documental por haberse realizado en metálico. No es fácil avanzar en esta cuestión a partir de la documentación escrita. Sin embargo, sí es posible profundizar en la datación del templo a través del estudio del proyecto y de las circunstancias históricas que lo envolvieron.

El diseño de la cabecera triabsidada se caracteriza por tener la capilla mayor poco sobresaliente con respecto a los ábsides laterales. Pese a que el ábside central románico fue sustituido por otro de mayor profundidad en el siglo XVIII, conocemos su trazado original gracias al plano dibujado por el arquitecto Antón Tornés ${ }^{117}$ (fig. 8). Sus dimensiones han podido ser constatadas recientemente con ocasión de intervenciones en el edificio. La cabecera, por tanto, presentaba en las tres capillas anteábsides de idéntica profundidad, de modo que difería de la que imaginó Francisco Íñiguez Almech (fig. 9), cuyo dibujo ha sido reproducido continuamente para ilustrar las historias del arte románico español (Íñiguez supuso que la profundidad de los anteábsides no era similar en las tres capillas, sino que guardaba proporcio-

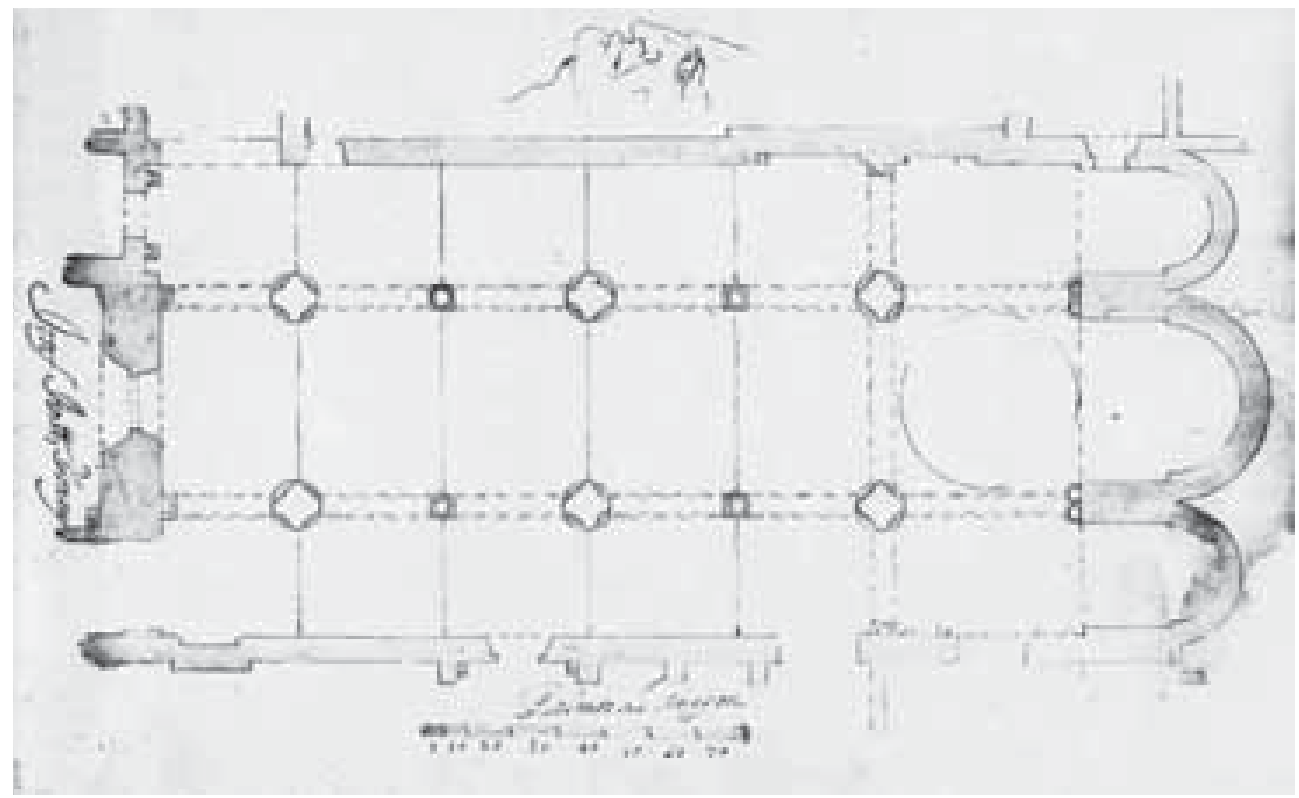

Fig. 8. Planta de la catedral de Jaca según el Libro de Trazas de Antón Tornés

hacen preciso reconsiderar el tejido urbano previo: J.I. Royo GuiLLÉn, "La arqueología urbana en Jaca y sus aportaciones", Comarca de la Jacetania, Zaragoza, 2004, pp. 61-72.

117 La planta fue dibujada en el llamado Libro de trazas de la arquitectura jacetana conservado en el Archivo Histórico Provincial de Huesca, Sección Archivos de Familias, Antón Tornés, signatura 71. Es accesible en Internet: http://servicios.aragon.es/opac/app/attachment/?a=e8/4d/AHPHU F 00071.djvu. Sobre el libro: N. JuAn GarCía, “Aproximación al estudio de un libro de trazas de los siglos XVIII-XVIII: el manuscrito de la familia Tornés", Libros con arte. Arte con libros, Cáceres, 2007, pp. 427-445. 


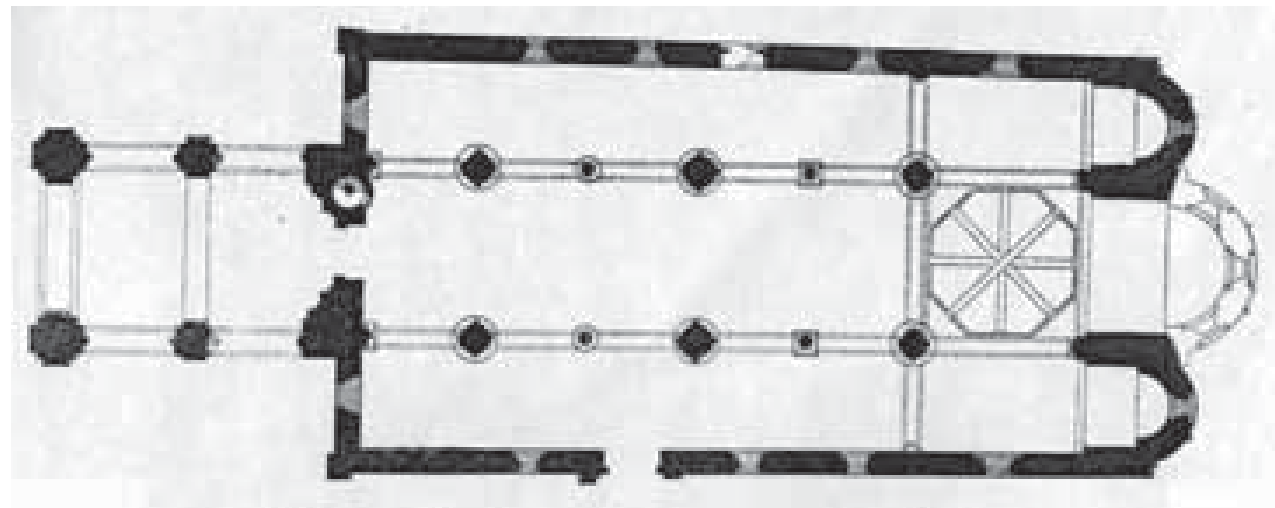

Fig. 9. Planta de la catedral de Jaca según Íñiguez

nalidad con su anchura, de suerte que el central habría de ser notablemente más profundo). Cabeceras con tres ábsides escalonados cuyos anteábsides presentan la misma profundidad, como los de Jaca, fueron frecuentes en Aragón y Cataluña a lo largo del siglo XI. Los vemos en la catedral de Roda de Isábena y Santa María de Obarra (iniciadas en el primer tercio), en San Pedro de Ager y San Jaime de Frontañá (obras promovidas por Arnau Mir de Tost en el segundo tercio) y en el Santo Sepulcro de Palera (consagrada en 1085). Otras iglesias de proyecto más o menos cuidado con tres ábsides que arrancan de la misma profundidad, aunque sin anteábsides destacados vemos en San Martín de Buil y, con menor refinamiento, en San Juan de Pano ${ }^{118}$. No obstante, en las mismas décadas se empleaban también los anteábsides disímiles, como apreciamos por ejemplo en San Vicente de Cardona. Todas estas iglesias participan de las formas propias del Primer Románico. En cambio, a finales de la centuria y en construcciones del Románico Pleno, con tratamiento de paramentos muy diferente e inclusión de relieves figurativos, los anteábsides de la misma profundidad resultan escasos ${ }^{119}$. En resumen, la cabecera de Jaca tiene más paralelos entre proyectos hispanos en el segundo y tercer cuartos del siglo XI que en sus años finales. Sin embargo, no sucede lo mismo si los referentes los tomamos en Italia, donde a finales del siglo emprendieron templos monumentales triabsidados cuyo anteábside central es poco más profundo que los laterales (catedral de Módena). Más adelante retomaremos este vínculo italiano.

Las dimensiones de la cabecera (anchura del anteábside central de Jaca: 7,13 $\mathrm{m})$, se mueven en la línea del único edificio catedralicio aragonés entonces existente, Roda de Isábena, y resultan muy superiores a las de los mayores monasterios, como Santa María de Obarra (las tres naves del primer tramo de Obarra alcanzan

118 Véanse planos e información completa sobre estas iglesias en Esteban, Galtier y García, Nacimiento.

119 Sobre la cabecera de Ujué y su relación con la catedral de Jaca: J. Martínez de Aguirre, voz "Ujué", Enciclopedia del Románico en Navarra, Aguilar de Campoo, 2008, vol. III, pp. 1423-1436; con mayor detalle: ID., "Arquitectura medieval", Santa María de Ujué, en prensa. 
una anchura de 12,60 m, mientras que las del primer tramo de Jaca miden 20,05 m). También están en los márgenes de los mayores cenobios y canónicas catalanes del primer románico (anchura del ábside central de Ripoll: 7,48 m; del anteábside central de Cardona: $6,54 \mathrm{~m}$ ). Y superan claramente al mayor empeño navarro (anchura del ábside central de Leire: $5,08 \mathrm{~m})^{120}$. Las dimensiones apuntan a que en Jaca desde el inicio se pensó en construir una catedral, puesto que sus medidas rebasan con mucho lo esperable en caso de que simplemente hubieran decidido renovar el monasterio de San Pedro el Viejo o instalar allí una canónica agustiniana no catedralicia.

He procurado demostrar en páginas previas que la construcción de la seo no se inició con un proyecto perteneciente al Primer Románico Meridional, sino que se planteó y construyó desde cimientos como un edificio del Románico Pleno, con su habitual manera de ejecutar paramentos, articular exteriores e interiores mediante columnas y molduras decoradas, e incorporar relieves susceptibles de asumir contenidos historiados en los puntos de transición de la estructura (muro-vano en puertas y ventanas, soporte-arco en los capiteles, muro-cubierta en las cornisas).

Todo ello es patente en el ábside meridional (fig. 10), caracterizado por su esmerada composición en horizontal, gracias a la presencia en el exterior de una hilada oblicua y dos molduras ajedrezadas; y en el interior, de tres molduras: la superior a la altura de la cornisa; la que prolonga los cimacios de los capiteles de las ventanas (casi completamente repicada, puede verse nítidamente en el ábside septentrional); y la que corre por debajo de la ventana (igualmente retallada). Como elementos verticales dispone de ventana axial y columna sobre zócalo ${ }^{121}$.

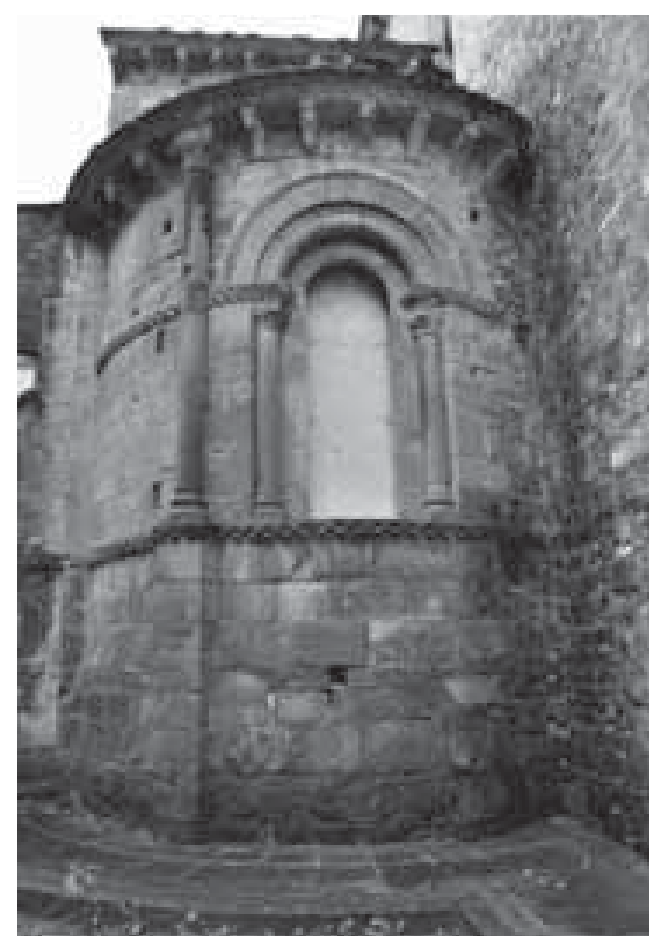

Fig. 10. Ábside meridional de la catedral de Jaca

120 Las dimensiones de Jaca están tomadas de J.F. Esteban LoRente, "La metrología de la catedral románica de Jaca: 1", Artigrama, 14 (1999), p. 243; las de los restantes edificios en ID., "La metrología y sus consecuencias en los edificios de la Alta Edad Media Española. III: El Primer Románico en España”, Artigrama, 22 (2007), pp. 423-472.

121 Fue alterada una porción de muro inmediata al ábside central, como se ve en la fotografía publicada por W.M. Whitehill, Spanish Romanesque Architecture of the Eleventh Century, Oxford, 1941, lámina 94. 
Si consideramos válidas las conclusiones basadas en el establecimiento de secuencias evolutivas, el estadio al que corresponde la distribución de molduras se manifiesta en Jaca más evolucionado (y en términos cronológicos, más tardío) que los de las cabeceras de Sainte-Foy de Conques, Saint-Sernin de Toulouse y San Martín de Frómista. En Conques y Saint-Sernin una única moldura recorre el exterior de los absidiolos envolviendo las ventanas (como en las iglesias de Auvernia), pero no hay moldura bajo las ventanas. En Frómista esta solución es aplicada de manera muy armónica, porque el arquitecto hizo coincidir la que recorre el muro a la altura de los cimacios de las ventanas de los ábsides laterales con la que marca el umbral de las ventanas del central y se prolonga por los muros de las naves; en paralelo, la moldura a la altura de los cimacios de las ventanas del ábside central coincide con la cornisa de los ábsides laterales. Conforme avance el Románico, la tendencia general de los más relevantes empeños constructivos conducirá hacia la solución de Jaca, en la que los cimacios enlazan con molduras que marcan horizontales a lo largo de la totalidad de los muros, tanto curvos como rectos, interiores como exteriores (hasta la exageración de Santa Marta de Tera).

En el interior de Toulouse, la mayoría de los cimacios de los capiteles se prolongan muy brevemente mediante moldura que carece de continuidad. Se trata de un recurso antiguo, que encontramos, por ejemplo, en San Pedro de Roda. Este detalle se combina con un juego de molduras que, como en Conques, no sigue los mismos principios que en Jaca o Frómista debido a la complejidad de las respectivas cabeceras con deambulatorio, por lo que no cabe resumirlo brevemente. En el interior de Frómista hay dos molduras, una bajo la ventana y otra en el arranque de la bóveda; falta la jaquesa a la altura de los cimacios justamente porque no hay cimacios, lo que nos lleva a hablar de la distribución de ventanas y columnas.

La combinación ventana-columna en el exterior del ábside meridional de Jaca parece corresponder a una adaptación no absolutamente armónica del expediente empleado en Frómista. En la iglesia palentina resplandecía la simetría ventanacolumna-ventana, como en Conques y Toulouse, en lo que es una actualización del antiquísimo ritmo conseguido mediante sucesión de arcos bajo dinteles soportados por columnas que caracterizó la arquitectura romana desde el final de la República. Sin embargo, dicha simetría fue abandonada en Jaca. Posiblemente una de las razones que motivaron el cambio compositivo entre Frómista y Jaca consistiera en que en el proyecto aragonés prevaleció el deseo de enmarcar el vano mediante columnas y arquivolta moldurada tanto al exterior como al interior. Este complemento decorativo no se aplicó en las ventanas tolosanas hasta la quinta etapa constructiva, la correspondiente a la edificación del muro de cierre de la tribuna según el ajustado proceso descrito por Cazes ${ }^{122}$. En Frómista se introdujo el enmarque ornamentado

122 Q. Cazes y D. Cazes, Saint-Sernin de Toulouse. De Saturnin au chef-d'oeuvre, Graulhet, 2008, p. 71 (en adelante citado: CAZES, Saint-Sernin). 
en el exterior de los ábsides, pero no en el interior. Una razón lo justifica: el arco descrito por el exterior de los ábsides laterales tiene evidentemente mayor longitud que el arco interior correspondiente, por lo que en el exterior había espacio para disponer el complemento ornamental sin que fuera necesario disminuir el tamaño del vano. En cambio, si se deseaba mantener un vano amplio con sus abocinamientos, no era posible la inclusión de enmarques con arquivolta y columna para dos ventanas, que interiormente quedaban muy juntas cuando la dimensión interna del ábside era tan pequeña como en Frómista o en Jaca. La inclusión de columnillas en el interior de los ábsides jaqueses obligó a la colocación de la tercera moldura ajedrezada horizontal, que hemos identificado como rasgo peculiar de Jaca en la secuencia evolutiva que estamos trazando.

Otro elemento constructivo, común en Frómista y Jaca, enlaza ambas y las caracteriza como secuelas de Saint-Sernin de Toulouse. Me refiero a las parejas de esbeltas columnas que en Jaca se sitúan en los frentes entre las embocaduras de los ábsides y en Frómista, en cambio, en el inicio de las naves. En Toulouse las columnas dobles aparecen duplicadas en el inicio del deambulatorio (tanto en la entrada septentrional como en la meridional, yuxtapuestas al muro y apeando los arcos del tramo recto de la girola), es decir, en un lugar que por su condición flanqueante (a diferencia de la disposición frontal jaquesa) resulta conceptualmente más cercano a la ubicación de Frómista ${ }^{123}$.

En el diseño de los soportes que exteriormente articulan los ábsides hay diferencias en el seguimiento que Frómista y Jaca hacen de los modelos franceses. En Conques y Saint-Sernin están formados por tres elementos: 1) zócalo inferior de perfil cuadrangular; 2) basamento semicircular a partir del nivel de los alféizares de las ventanas; y 3 ) columnillas por encima de la moldura a la altura de la imposta de los arcos de las ventanas. Frómista prescinde del zócalo inferior cuadrangular de manera que el semicircular va desde el suelo hasta los alféizares, seguido por columna desde ese nivel hasta la cornisa. En Jaca, en cambio, es el zócalo cuadrangular entre el suelo y el nivel del alféizar el que sostiene la columna hasta la cornisa. En cuanto a los óculos, ni en Frómista ni en Jaca se emplean como en Toulouse o Conques, ya que no tienen girola (sí los hay en Santiago de Compostela); en Jaca se reservan para el muro occidental (y para el cimborrio, como en Loarre) y en Frómista hoy no existen, aunque conviene recordar que su muro occidental actual es producto de la restauración.

Vistos todos estos elementos en su probable secuencia evolutiva, el análisis arquitectónico nos lleva al encadenamiento Toulouse $\rightarrow$ Frómista $\rightarrow$ Jaca. Los proyectos de Frómista y Jaca han de ser muy cercanos en el tiempo, puesto que muestran

123 En Santiago de Compostela, que hizo evolucionar hacia su propio rumbo las fórmulas tolosanas, no hay parejas de columnas, lo que evidencia que en este concreto aspecto nada tiene que ver Santiago con Frómista y Jaca. Sin duda la colocación de las dobles columnas en Saint-Sernin deriva de la presencia de tales elementos en los accesos a las cabeceras, nada extraña en edificios anteriores al año mil. 
variantes ligeramente diferentes derivadas del mismo tronco común (fig. 11). El final de esta secuencia, es decir, el nexo Frómista $\rightarrow$ Jaca, está en la línea de lo defendido por Moralejo para determinados capiteles de la portada y el interior de la catedral jaquesa, puesto que los capiteles palentinos, en cuanto a su dependencia del sarcófago de Husillos, manifiestan un estadio anterior a ciertas obras de Jaca ${ }^{124}$. Sin embargo, no puedo estar de acuerdo con el juicio de Moralejo acerca del "carácter más evolucionado que reviste la arquitectura de la iglesia palentina en relación a la jaquesa" 125 , carácter que -como acabamos de ver-el estudio comparativo de Conques, Toulouse, Frómista, Jaca y Compostela no confirma ${ }^{126}$.

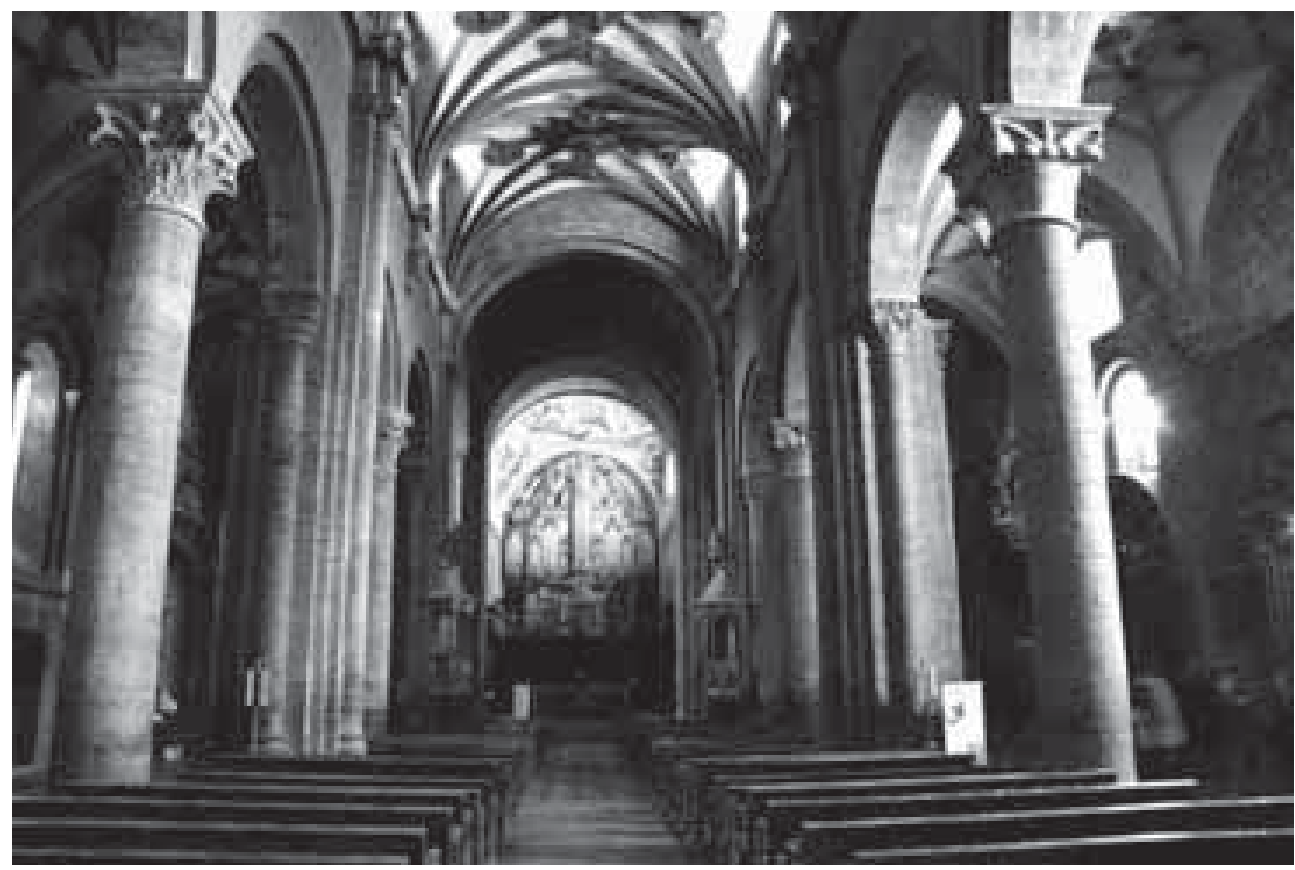

Fig. 11. Interior de la catedral de Jaca

124 S. Moralejo. "Sobre la formación del estilo escultórico de Frómista y Jaca", Actas del XXIII Congreso Internacional de Historia del Arte. Granada 1973, I, Granada, 1976, pp. 427-434 (en adelante citado: Moralejo, "Formación"; ID., "La sculpture romane de la cathédrale de Jaca. État des questions", p. 84. Es de señalar que recientemente se han propuesto perspicaces avances en lo planteado por Moralejo: F. PRADOVILAR, "Saevum facinus: estilo, genealogía y sacrificio en el arte románico español”, Goya, 324 (2008), pp. 173-199, y "Lacrimae rerum: San Isidoro de León y la memoria del padre”, Goya, 328 (2009), pp. 195-221.

125 Moralejo, "Formación”, p. 432; y más adelante: "El proyecto arquitectónico de Jaca, e incluso su realización en las partes bajas no esculturadas, puede y debe probablemente ser anterior al inicio de los trabajos en Frómista, por lo que reflejaría lógicamente soluciones más arcaicas".

126 Jaca presenta, eso sí, un peculiar tratamiento del aparejo, con hiladas que se inician con sillares de grandes dimensiones y luego se desdoblan, pero sin que existan hiladas perdidas a la manera prerrománica. Este aparejo es peculiar de Jaca y su entorno, y no lo tenemos como antecedente en Toulouse o Conques, ni tampoco en Frómista o Compostela. Por el momento no he localizado ningún elemento en Frómista que evidencie el recurso a una solución de raigambre tolosana utilizada tal y como fue entendida en Jaca, que pudiera justificar una precedencia aragonesa con respecto al templo palentino. 
El análisis de la escultura plantea mayor complejidad. Junto a las fórmulas que llegaron a Jaca desde Frómista, otras vinieron directamente de Toulouse, de manera que existió un fluir en doble dirección Toulouse $\rightarrow$ Jaca $\rightarrow$ Toulouse estudiado por Lyman, Moralejo y Durliat, entre otros ${ }^{127}$. Los vínculos más concretos entre los templos aragonés y tolosano corresponden a la quinta etapa de Saint-Sernin (según la periodización de Cazes), fase cronológicamente relacionable con la consagración del templo por el papa Urbano II en 1096, ya que han sido identificados capiteles del estilo de Bernardo Gilduino en distintos lugares de la tribuna del transepto ${ }^{128}$. Se impone como tarea futura recoger el testigo y llevar a cabo una aproximación pormenorizada que permita establecer el carácter simultáneo o sucesivo de campañas interrelacionadas en edificios como estos, cuyos trabajos se dilataron durante décadas ${ }^{129}$.

No es fácil establecer hitos cronológicos absolutos para la edificación catedralicia, dada la problemática documentación y las dificultades de fechar Saint-Sernin y Frómista. Admitamos, con los últimos y magníficos estudios de Quitterie y Daniel Cazes $^{130}$, que la cabecera de Saint-Sernin se inició después de 1073, pero que pudo avanzar a un ritmo rápido gracias a que venían recaudando fondos con destino a las obras desde mediados de siglo. El inicio de Frómista no podría ser anterior y el de Jaca iría a continuación, con muy poca dilación. Son evidentes las coincidencias cronológicas entre el acceso a la soberanía del rey aragonés (1076), la concesión del fuero a Jaca (1076-1077) y un comienzo de las obras acorde con la cronología planteada por Ubieto y aceptada en términos histórico-artísticos por Moralejo ${ }^{131}$. Hay más. El asesinato de Sancho el de Peñalén tuvo lugar el 4 de junio. El primer documento en que García, hermano de Sancho Ramírez, aparece como obispo de

127 T.W. Lyman, "Notes on the Porte Miègeville Capitals and the Construction of Saint-Sernin in Toulouse", The Art Bulletin, XLIX (1967), pp. 25-36 (especialmente p. 28); S. MoraleJo, "Une sculpture du style de Bernard Gilduin à Jaca", Bulletin Monumental, CXXXI (1973), pp. 7-16; M. DurLiat, "Toulouse et Jaca", Homenaje a Don José María Lacarra de Miguel en su jubilación del profesorado. Estudios Medievales I, Zaragoza, 1977, pp. 197-207. La complejidad de estas relaciones fue magistralmente planteada por S. Moralejo, "Modelo, copia y originalidad, en el marco de las relaciones artísticas hispanofrancesas (siglos XI-XIII)", Vè Congrés Espanyol d'Historia de l'Art. Barcelona; 29 d'octubre al 3 de novembre de 1984, Barcelona, 1986, pp. 89-112 (especialmente pp. 91-99).

128 CAZES, Saint-Sernin, p. 72.

129 De cualquier modo, no considero definitivas las conclusiones aquí alcanzadas, hasta que puedan verificarse con el estudio individualizado de cada uno de los motivos ornamentales esculpidos en Frómista y Jaca, así como su relación con Toulouse, no sólo los que incluyen personajes (que han atraído de manera prioritaria el interés de mayor número de estudiosos), sino muy especialmente los vegetales, los entrelazos y los zoomórficos, labor prevista dentro del proyecto de investigación ya mencionado.

130 CAzEs, Saint-Sernin, p. 62.

131 La propuesta fue aceptada por los estudiosos del edificio del Románico Pleno con mayor proyección internacional, como Moralejo (delimita el plazo entre 1077 y 1098: S. Moralejo Álvarez, "La sculpture romane de la cathédrale de Jaca. État des questions”, Les Cahiers de Saint-Michel de Cuxa, 1979, p.79), Durliat, que lo retrasa algo más ("Par sa structure, la cathédrale de Jaca corresponde à une église conçue et réalisée à la fin du XI ${ }^{\mathrm{e}}$ et au début du XII siècle": M. DuRliat, La Sculpture Romane de la Route de SaintJacques. De Conques à Compostelle, Dax, 1990, p. 222); y D.L. Simon, La catedral de Jaca y su escultura. Ensayo, Jaca, 1997, pp. 6-9. 
Jaca data, según Durán Gudiol, de 9 de octubre de $1076^{132}$. Y poco después, aunque no sea posible concretar la fecha exacta, tuvo lugar la reforma canónica de Jaca, entre 1076 y 1079, cuyo diploma encabeza García y suscribe el rey. Consistió en la expulsión de los clérigos que vivían ritu secularium y su sustitución por otros que llevaran vida común, iuxta apostolicam tradicionem, conforme a la regla de San Agustín ${ }^{133}$. En fechas cercanas el monarca concedió fuero a los habitantes de Jaca (1076-1077), lo que facilitó la constitución de un marco adecuado a la realeza en el territorio que consideraba propio, que en paralelo a su elevación a la categoría de rex gratia Dei adquiría la condición de regnum. Para ello necesitaba una capital que fuera ciuitas, por lo que modificó el status de Jaca, como indica el ampuloso prólogo del fuero, en el que no se recata de anunciar la acción a todo el orbe: Notum omnibus hominibus qui sunt usque in orientem et hoccidentem et septentrionem et meridiem, quod ego volo constituere civitatem in mea villa que dicitur Iaka ${ }^{134}$.

El corolario de estas acciones sería la creación de una catedral en la que los canónigos desarrollaran su culto de manera magnífica, el obispo de Aragón encontrara sede definitiva y los monarcas celebraran los actos más solemnes de la reale$\mathrm{za}^{135}$. Pudo haberse tomado la decisión el mismo año de 1077 o hacia 1080 . Consta que la boda del futuro Pedro I con Inés de Aquitania tuvo lugar en 1086 en Jaca, puesto que nos han llegado noticias en dos documentos distintos ${ }^{136}$. Quizá para entonces las obras de la catedral habrían avanzado lo suficiente como para acoger una solemnidad de estas características (aunque no hemos de olvidar que San Pedro el Viejo seguía en pie). Es una lástima que el testamento de Urraca, hermana de Sancho Ramírez, en que deja bienes ad labore de Sancti Petri de Iacha carezca de fecha, porque sería un indicio valiosísimo para datar los trabajos catedralicios. Su editor, Antonio Ubieto, lo fechó en 1077-1078, pero bien pudiera ser posterior ${ }^{137}$.

132 A. Durán Gudiol, La Iglesia de Aragón durante los reinados de Sancho Ramírez y Pedro I (1062?1104), Roma, 1962, p. 37.

133 El texto con su traducción en D. Sangorrín y Diest-Garcés, El Libro de la Cadena del Concejo de Jaca. Documentos Reales, Episcopales y Municipales de los siglos X, XI, XII, XIII y XIV, Zaragoza, 1920, pp. 63-73 (en adelante citado: SANGorrín, El Libro de la Cadena).

134 A. Ubieto Arteta, Jaca: documentos municipales 971-1269, Valencia, 1975, doc. 8, p. 49.

135 No ha quedado memoria del hipotético ritual con que Sancho Ramírez asumió la condición de Dei gratia rex. Pudo haber sido en Pamplona, donde las coronaciones de los reyes medievales que conocemos (muy posteriores) se hicieron siempre en la catedral, pero no es descartable que celebrara algún rito en territorio aragonés. ¿Tendrán algo que ver con la hipotética coronación o con la previsión de futuras ceremonias regias las llamadas "tapas de evangeliario" procedentes de Santa María de Santa Cruz de la Serós (Museo Metropolitano de Nueva York)? Es bien sabido que los monarcas juraban sobre la cruz y los santos evangelios, por lo que una pieza de estas características sería imprescindible para los ritos que comentamos. Las noticias más antiguas sobre coronaciones de reyes aragoneses, según Durán, datan de 1204 y se refieren a Pedro II: A. Durán Gudiol, "El rito de la coronación del rey en Aragón”, Argensola, n 103 (1989), p. 18.

136 Hec autem carta fuit facta in Iacca quando nuptias feci in mense ianuario: A. UBIETo ArTETA, Colección Diplomática de Pedro I de Aragón y Navarra, Zaragoza, 1951, doc. 1 (p. 211). Incluye pequeñas variantes A. Durán Gudiol, Colección Diplomática de la Catedral de Huesca. Vol. I, Zaragoza, 1965, doc. 51 , p. 69.

137 A. Ubieto Arteta, Cartulario de Santa Cruz de la Serós, Valencia, 1966, doc. 8. El hecho de que no aparezca su hermano García como obispo podría llevar a pensar en una redacción posterior a 1086. 
Tampoco sabemos interpretar con certeza si la referencia que aporta la Crónica de San Juan de la Peña tiene algo que ver con la edificación del templo o se refiere a obras en la canónica: "En el anno de Nuestro Sennyor M LXXXVIII', en el mes de mayo, el dito rey edificó el monesterio de Montearagón et la calongía de Jaca"138.

Casi todos los estudiosos han señalado la existencia de fases sucesivas en la construcción de la catedral, pero no coinciden ni en fechas ni en alcance de las campañas. El hecho de que muchos capiteles aparezcan suplementados, detalle que llamó la atención de Íñiguez, Moralejo, Simon y Bango, entre otros, así como la falta de sintonía entre pilares y muros, ha hecho suponer que al menos los pilares de las naves fueron erigidos por un segundo arquitecto. La distribución de soportes de las naves resulta atípica en el románico hispano. Los muros carecen de contrafuertes, lo que los emparenta con tradiciones y con templos pioneros, como Leire o Frómista ${ }^{139}$; en plantas antiguas fueron dibujados elementos susteantes, que hoy no se conservan. Se da una alternancia de soportes internos: pareja de pilares compuestos de núcleo cruciforme junto al transepto, seguidos hacia los pies por poderosas columnas, pilares compuestos de triple rincón, de nuevo columnas y, para terminar, pilares compuestos cruciformes semejantes a los primeros. Está claro que no se trata de una simple evolución de la alternancia pilar-columna empleada con torpeza en la cripta legerense (1025-1058), sino de la adopción de un sistema sabio, monumental y bien proporcionado, atribuible a un arquitecto de cuidada formación. La solución adoptada para las cubiertas, que combina abovedamiento en la cabecera y transepto (con una cúpula nervada sobre el crucero de diseño atípico) y techumbre lignaria en las naves, no sólo contrasta con lo habitual en los templos monumentales del siglo XI en tierras ibéricas, sino también -como ha visto acertadamente David Simon- con lo normal en las grandes construcciones hispanolanguedocianas que contienen escultura relacionada con Jaca. Con gran perspicacia, el investigador americano ha relacionado la cubierta de madera con la fórmula típica de las basílicas paleocristianas, de modo que su empleo en la seo aragonesa manifestaría un particular interés por recordar la basílica de San Pedro de Roma. Para justificar este hecho, ha recordado los vínculos de Sancho Ramírez con el papado que hemos examinado con anterioridad ${ }^{140}$. De este modo, el complejo desarrollo de la fábrica catedralicia incorpora elementos que encuentran su explicación no en una simple recepción de formas procedentes del entorno artístico cercano, sino en la voluntad de transmitir significados relacionables con los avatares del reino aragonés ${ }^{141}$.

138 C. Orcástegui Gros, Crónica de San Juan de la Peña. (Versión aragonesa). Edición crítica, Zaragoza, 1986, p. 37.

139 Y también con el cuerpo de Loarre, donde el único contrafuerte se sitúa inmediato a la cabecera.

140 D.L. Simon, La catedral de Jaca y su escultura. Ensayo, Jaca, 1997, pp. 15-16. Aunque dichos vínculos vivieron momentos de especial intensidad en el viaje a Roma de Sancho Ramírez en 1068 y la revitalización del vasallaje hacia 1088-1089, conocemos otras visitas de importantes personajes aragoneses vinculados a la catedral tanto en los años setenta como en los ochenta.

141 Quizá sea significativo que el resultado final de las formas catedralicias resulte nítidamente distinto de lo que se estaban haciendo en Castilla y León o en Cataluña. ¿Cabría ver un deseo consciente de dife- 
Pasando al terreno de la escultura, varios estudiosos han vinculado el crismón o alguno de los capiteles de la portada occidental con preocupaciones propias de la monarquía. A relaciones obvias, como las establecidas con los crismones que encabezan los diplomas regios de la época, se han sumado otros significados. Por ejemplo, David Simon ha recordado "la importancia histórica del crismón como símbolo de la victoria de Constantino (...), especialmente adecuada para Jaca en un momento en el que las fuerzas y energías de la ciudad se encontraban ocupadas en la reconquista" y Dulce Ocón ha captado en él "un nuevo significado, el de la fidelidad de los monarcas aragoneses a la Santa Sede"142.

Desde esta óptica, aunque de manera más sutil, es apreciable que ciertos motivos escogidos para los relieves, así como los textos que los explican, inciden en el ejercicio de la ley y la introducción de nuevas normas. Según Gonzalo Menéndez Pidal, fue a mediados del siglo XI cuando cambió la leyenda que envuelve las cruces iluminadas en manuscritos hispanos altomedievales para incluir "cuatro palabras programáticas: PAX, LUX, LEX, REX, tal vez adoptadas por Fernando I"143. Ya hemos tenido ocasión de comentar hasta qué punto el conocimiento de la ley formaba parte del sustrato conceptual de la realeza pamplonesa desde finales del siglo $\mathrm{X}$ y su ejercicio se revelaba como un acto de manifestación de la majestad, llevando a la práctica la equivalencia $r e x=l e x^{144}$. Pues bien, las inscripciones que recorren el tímpano incluyen dos veces términos directamente alusivos a la ley (fig. 12). En primer lugar, la grabada en el círculo del crismón: HAC IN SCULPTURA LECTOR SIC NOSCERE CURA P PATER, A GENITUS, DUPLEX EST SPIRITUS ALMUS HII TRES IURE QUIDEM DOMINUS SUNT UNUS ET IDEM. Iure, adverbio derivado de ius, puede traducirse 'con razón', 'justamente', 'con justo título', y no corresponde en lo que conozco a una fórmula consagrada ni obedece a razones de métrica o rima. En segundo lugar, en la base del tímpano se lee una cita directa a la ley: VIVERE SI QUERIS, QUI MORTIS LEGE TENERIS, HUC SUPLICANDO VENI, RENUENS FOMENTA VENENI, COR VICIIS MUNDA, PEREAS NE MORTE SECUNDA. Ambas expresiones podían haber sido formuladas mediante otros términos, puesto que el adverbio iure es innecesario para proclamar el contenido dogmático trinitario y la alusión a la vida terrena

renciación, en la línea del alejamiento de lo castellano-leonés y de la tradición condal perceptible en otras actuaciones coetáneas de Sancho Ramírez?

142 D.L. Simon, "El tímpano de la catedral de Jaca", Congreso de Historia de la Corona de Aragón. Jaca 1993. Actas t. III, Zaragoza, 1994, p. 417. D. Ocón Alonso, "El sello de Dios sobre la iglesia: tímpanos con crismón en Navarra y Aragón", El tímpano románico. Imágenes, estructuras y audiencias, Santiago de Compostela, 2003, p. 97.

143 G. MenÉndez Pidal, "El lábaro primitivo de la Reconquista. Cruces asturianas y cruces visigodas", Boletín de la Real Academia de la Historia, CXXXVI (1955), p. 293.

144 En el extraordinario privilegio de donación de Úcar, cuya redacción supera a cualquiera de los documentos previos de la cancillería de Sancho, aparece la calificación de Dios como juez justo y rey de reyes (Deus, qui est iustus Iudex et regum Rex): Salarrullana, Documentos, XVI, p. 36. Fue emitido en 1077, el año de la concesión de fueros a Jaca. 


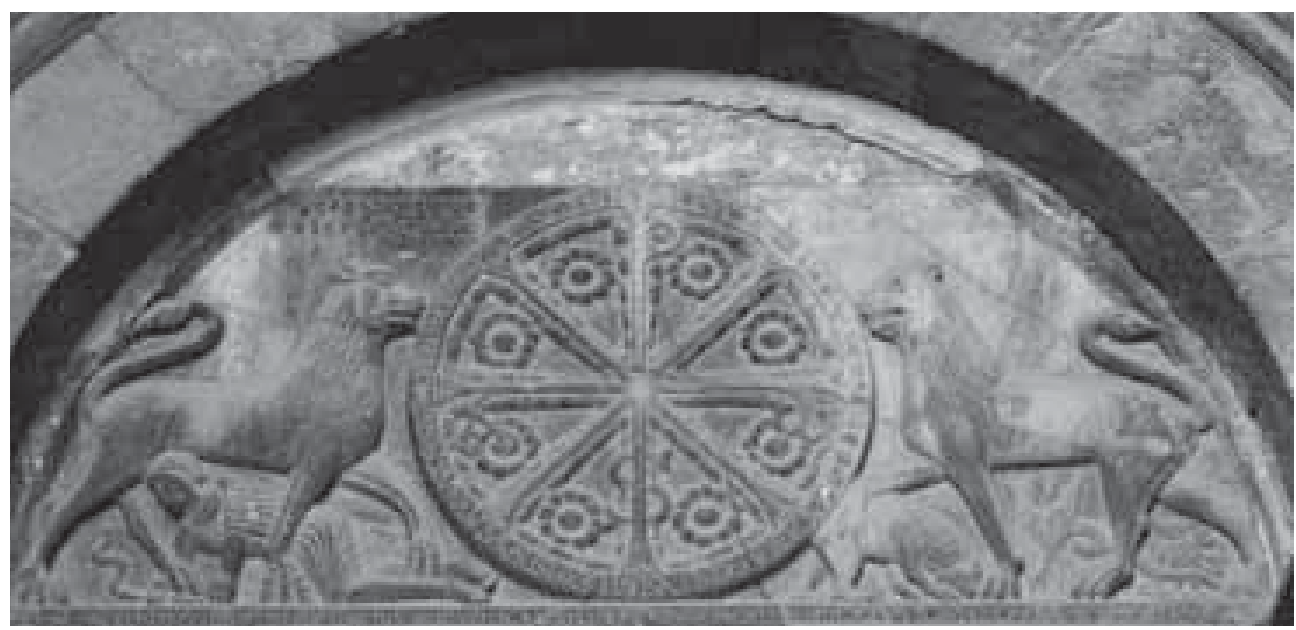

Fig. 12. Tímpano de la portada occidental de la catedral de Jaca

podía haberse realizado sin recurrir a la palabra lex La expresión empleada, lege mortis, está tomada de la epístola de San Pablo a los romanos $($ Ro 8, 2) donde todavía es más explícita la mención a la ley, en este caso a una ley superior, la de Jesucristo, sobre la mosaica: Lex enim spiritus vitae in Christo Iesu liberavit me a lege peccati et mortis.

La ley se hace igualmente presente en la interpretación más probable del capitel figurativo situado a la izquierda del observador ${ }^{145}$. David Simon vio en él la representación de dos pasajes de la vida de Moisés. En una cara aparecería en compañía de Aarón portando ambos un libro (fig.13); en la otra, con la vara con la que hizo milagros y guió al pueblo escogido ${ }^{146}$. Simon llama la atención sobre el hecho de que en época medieval emperadores y reyes fueran denominados en ocasiones nuevos Moisés. Muy concretamente, una bula de 1084 o 1085 de la que ya hemos hablado, llama al rey aragonés quasi alter Moyses por su papel en la introducción de la lex romana (abiecta Toletane illusionis supersticione legem ac consuetudines Romanas recepit) ${ }^{147}$. La composición de los dos personajes que

145 También alude a la justicia la interpretación de M. DuRLIAT, La sculpture romane de la route de Saint-Jacques. De Conques à Compostelle, Dax, 1990, p. 247, quien defiende reconocer en el objeto "la «piedra de justicia», la piedra que es Cristo engendrado por la Virgen María, sobre la cual la serpiente ha desenrollado sus anillos sin penetrarla, puesto que la tentación que atacó a Cristo desde el exterior no pudo penetrar en él”.

146 D.L. Simon, “A Moses capital at Jaca”, Imágenes y promotores en el arte medieval. Miscelánea en homenaje a Joaquín Yarza Luaces, Bellaterra, 2001, p. 215.

147 P. KeHR, "Cómo y cuándo", pp. 314-317. Curiosamente, en este caso nos da lo mismo que la bula sea original, como opinaba Kehr, o una falsificación ejecutada en Jaca hacia 1100, porque en ambos casos tendríamos la evidencia de la comparación del monarca con Moisés como introductor de la ley (romana) en fechas muy cercanas a la ejecución de la portada. Años más tarde, en el documento de dotación de la catedral de Huesca (1097), Pedro I compara a los hispanos con los israelitas que habían estado 460 años bajo el yugo egipcio. Es muy posible que esta conciencia de pueblo oprimido, del que les liberaría un caudillo que con esta 


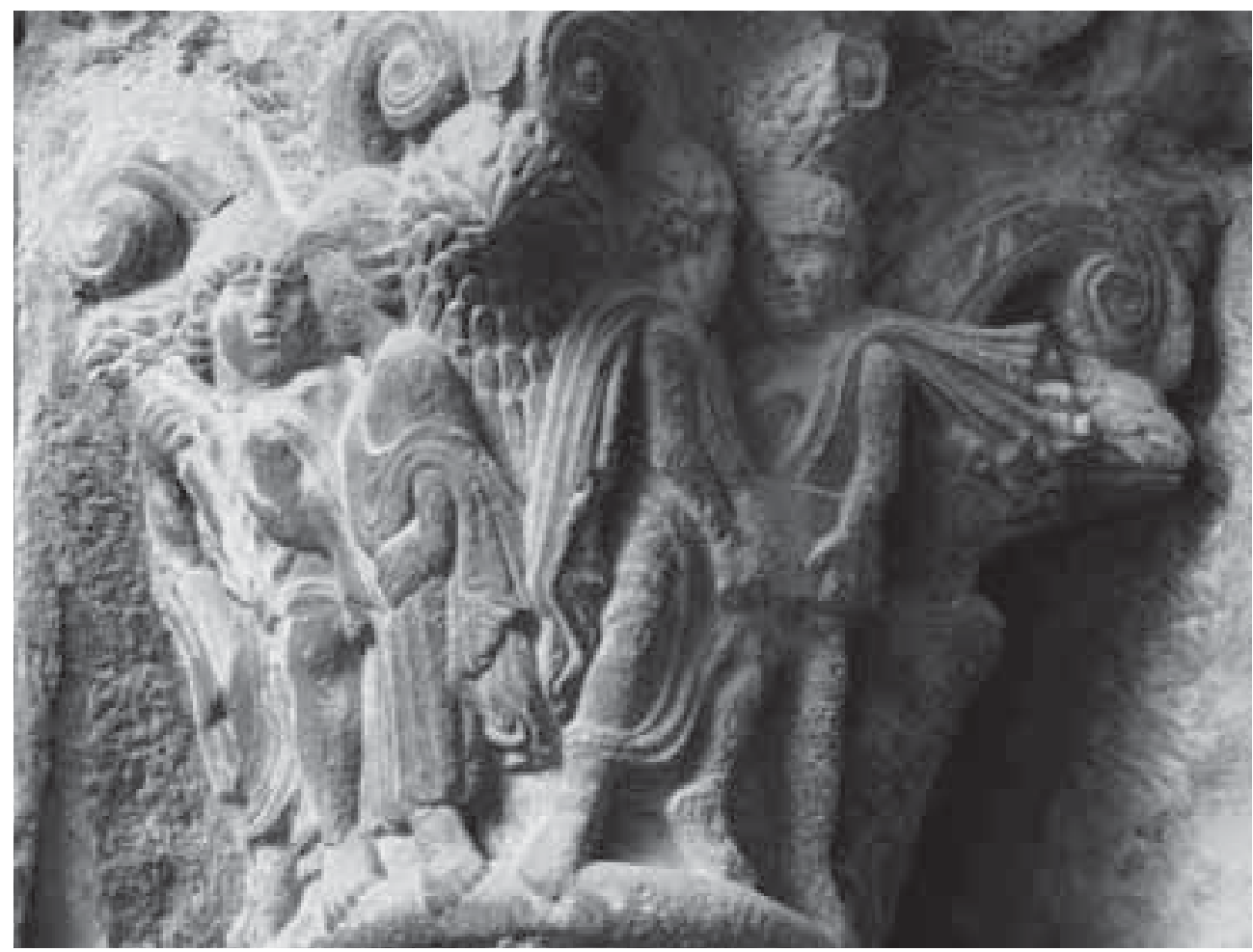

Fig. 13. Capitel de Moisés en la portada occidental de la catedral de Jaca

portan el objeto cuadrado (identificado con un libro según Simon) recuerda fuertemente a la empleada en la portada de San Isidoro de León como imagen de signo zodiacal de Géminis (fig. 14). En el agudo estudio que dedicó a los signos del zodíaco en San Isidoro, Moralejo expuso que según Zenón de Verona (siglo IV) Géminis era la imagen de los dos testamentos ${ }^{148}$. La migración significativa en Jaca sería así sencilla, puesto que los hermanos astrales portarían la Ley dada por Dios en el Antiguo Testamento y renovada por Cristo en el Nuevo. En consecuencia, es posible imaginar que quien ideó la composición del capitel jaqués tuviera en la cabeza una imagen habitual en la iconografía de Géminis, procedente del mundo clásico pero ya cristianizada, y que la empleara en Jaca para figurar a dos hermanos, Moisés y Aarón. La bula citada comparaba al rey de Aragón con Moisés como introductor de la Ley, pero en la imagen advertimos que el protagonismo se reparte entre ambos hermanos. No me parece exagerado poner esta par-

acción se haría semejante a Moisés, estuviera ya presente en el entorno de Sancho Ramírez, padre de Pedro I: A. Ubieto Arteta, Colección diplomática de Pedro I de Aragón y Navarra, Zaragoza, 1951, doc. 30, p. 251.

148 S. Moralejo Álvarez, "Pour l'interprétation iconographique du portail de l'Agneau à Saint-Isidore de León: les signes du zodiaque", Patrimonio artístico de Galicia y otros estudios. Homenaje al Prof. Dr. Serafin Moralejo Álvarez, Santiago de Compostela, 2004, t. I, p. 120. 
ticular escena en relación con el hecho de que Sancho Ramírez hubiera ordenado la introducción de la nueva ley en la diócesis a partir de su recepción en San Juan de la Peña y que hubiera colaborado con su hermano el obispo García en la implantación de la nueva norma que regiría a partir de 10761079 la vida de los canónigos de la catedral ${ }^{149}$.

Los capiteles del otro lado cuentan la historia de Daniel. Desde los estudios de Simon y Moralejo existe consenso en identificar uno de los temas con la ayuda prestada por el profeta Habacuc a Daniel cuando éste se encontraba en el pozo de

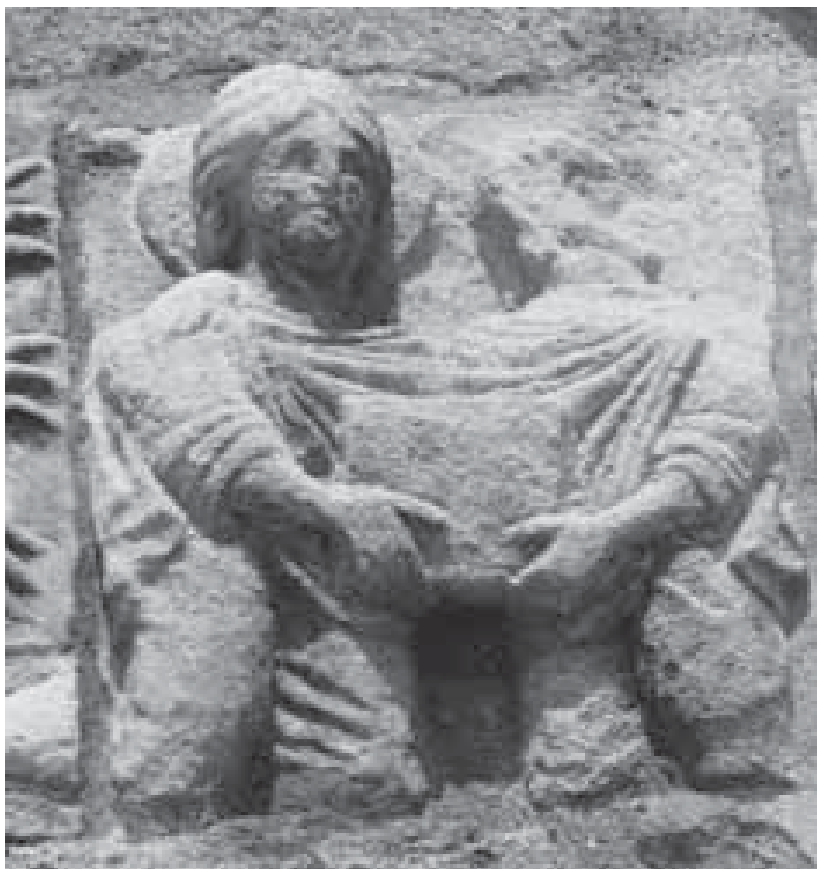

Fig. 14. Signo de Géminis en la portada del Cordero de San Isidoro de León

los leones ${ }^{150}$. Se ve perfectamente la figura de Daniel sedente, acompañado de dos cabezas de fieras, mientras recibe un objeto redondo de las manos del personaje que llega desde la izquierda sujeto por los cabellos por el ángel (fig. 15). No ha obtenido la misma aceptación la hipótesis identificativa del capitel situado a su lado defendida por el mismo Moralejo (fig. 16). En su opinión representa la escena en que el propio Daniel muestra ante los espantados sacerdotes de Bel el cuerpo de la serpiente que adoraban, a la que ha dado muerte con una bola de grasa, pelos y pez ${ }^{151}$. Esta propuesta a mi entender es la más convincente de las hasta ahora planteadas, aun reconociendo que el tamaño de la serpiente dificulta que veamos en ella la figuración de la divinidad adorada por los babilónicos (draco magnus la llama la Vulgata). El tema es perfectamente pertinente con relación al Moisés del capitel enfrentado ya que la historia de Daniel y la serpiente se relaciona con las

149 Y no debemos pasar por alto que Sancho Ramírez sin duda era visto por sus contemporáneos y especialmente por los jacetanos como la figura que había traído la nueva ley (fueros) con la que se regían las relaciones terrenas.

150 D.L Simon, "Daniel and Habakkuk in Aragon", Journal of the British Archeological Association, XXXVIII (1975), pp. 50-55; S. Moralejo ÁlVAREZ, “Aportaciones a la interpretación del programa iconográfico de la catedral de Jaca", Homenaje a don José María Lacarra de Miguel en su jubilación del profesorado. Estudios Medievales. I, Zaragoza, 1977, pp. 179-188.

151 Ibídem, pp. 188-190. 


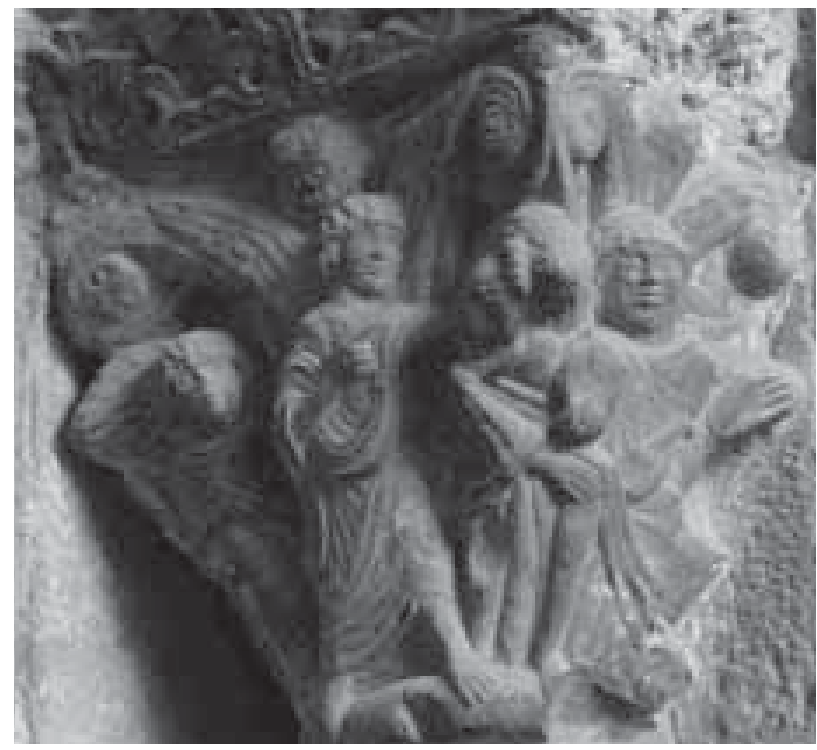

Fig. 15. Capitel de Daniel en el foso de los leones de la portada occidental de la catedral de Jaca.

circunstancias en que desarrolló su labor el obispo García, con el respaldo del rey. En la ya citada confirmación de la introducción de la vida canonical en Jaca, García expone cómo había terminado con "la perversión resultante de la pestífera herejía simoníaca" y había corregido "las malas costumbres de los clérigos que vivían al modo de seglares y usaban en particular de los bienes de la Iglesia como si fueran propios". Unas líneas más adelante, el propio Sancho Ramírez deplora los vicios de la antigua vida eclesiástica desordenada, concretamente el escándalo que habían de sufrir los fieles al ver que "sus limosnas y donaciones, hechas para el perdón de sus pecados (...) los gastan en particu-

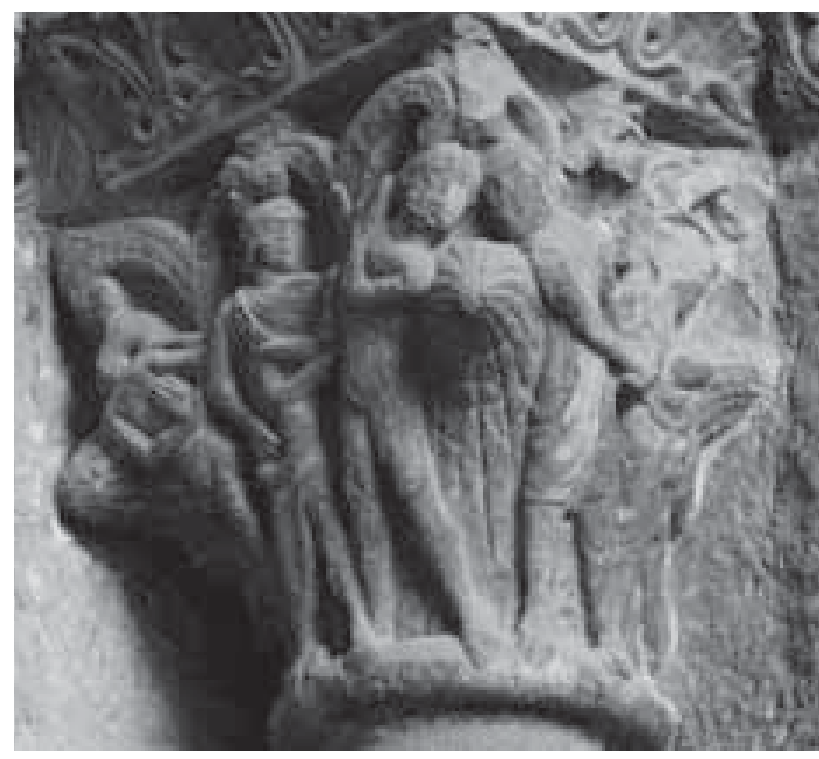

Fig. 16. Capitel de Daniel con la Serpiente Bel en la portada occidental de la catedral de Jaca. lar cual si fuesen propios y no procediesen de la heredad del Señor"152. Recordemos la historia de los sacerdotes de Bel, que en compañía de sus familias comían y bebían las ofrendas a la falsa divinidad y por su engaño fueron castigados (Dn 14, 1-28). Leído así el conjunto de capiteles, encontraríamos en un lado la imagen de Moisés-Sancho Ramírez acompañado de su hermano Aarón-García como introductores de la nueva ley; y en el otro, a Daniel-García que (con el respaldo de su hermano) terminó con los vicios de los sa-

152 El texto con su traducción en SANGorrín, El Libro de la Cadena, pp. 63-73. 
cerdotes de Bel-clérigos simoníacos gracias a la institución de la norma agustiniana en la canónica ${ }^{153}$.

Por último, no creo irrelevante el hecho de que Daniel fuese identificado en el Antiguo Testamento como modelo de quien busca la justicia a través de la historia de Susana (Dn 13), lo que sería acorde con el componente relacionado con la ley que aflora en la puerta. Antes de pasar a otro apartado, me gustaría dejar claro que estas connotaciones jurídicas en ningún modo sustituyen e invalidan los significados hasta ahora expuestos de tipo dogmático, penitencial y salvífico presentes en el crismón, los leones o el tema de Daniel en el foso. Estamos ante un ejemplo más de espesor significativo en el que, conforme al pensamiento medieval, distintos significados se presentan a un mismo tiempo a través de una única representación sin anularse entre sí.

\section{Excursus: la inscripción de Santa María de Iguácel}

La revisión de la cronología de la catedral jaquesa ha encontrado grave contradicción en los datos aportados por la inscripción de Santa María de Iguácel ${ }^{154}$. Desde el estudio del edificio por A. Kingsley Porter ${ }^{155}$ fueron advertidas las relaciones formales entre su escultura y la catedral de Jaca, así como la relevancia del epígrafe que ocupa la parte alta de la portada (fig. 17), que da noticia de los promotores de la iglesia (Sancho Galíndez, eitan o ayo del rey Sancho Ramírez, y su esposa Urraca), de la colaboración del monarca, de los autores del texto y del año de terminación ${ }^{156}$ :

HEC EST PORTA D(OMI)NI VNDE INGREDIVNTVR FIDELES IN DOMUM D(OMI)NI QVE EST ECGLESIA IN HONORE S(AN)C(T)E MARIE FVNDATA : IVSSU SANTIONI COMITIS EST FABRICATA VNA CU(M) SUA CONIVGE N(OMI)

153 La interpretación aquí planteada aporta nuevos argumentos para la datación de la portada occidental, puesto que reflejaría un período de buenas relaciones entre Sancho Ramírez y García, lo que descarta ciertos años en la década de los ochenta en que hubo enfrentamiento entre los hermanos. Pero prefiero dejar para otra ocasión mis precisiones con respecto a este asunto, ya que necesito traer a colación cuestiones de las que no he tratado y que requieren cierto desarrollo.

154 "La date de 1072, apportée par Iguácel, demeure encore l'argument le plus solide en faveur d'une chronologie précoce": S. Moralejo, "Une sculpture du style de Bernard Gilduin à Jaca", Patrimonio artístico de Galicia y otros estudios. Homenaje al Prof. Dr. Serafin Moralejo Álvarez, Santiago de Compostela, 2004, I, p. 58, n. 10 .

155 A.K. PorTer, "Iguácel and more romanesque art of Aragón”, The Burlington Magazine, LII (1928), pp. $115-127$.

156 Seguimos básicamente la transcripción de Durán Gudiol con pequeñas correcciones a partir de fotografías; sólo es relevante en la indicación de la fecha (Durán omitía la a encima de la X del ordinal, que sí leyó Porter) y el nombre del rey (Radimiriz como había leído Porter): A. DuRÁN Gudiol, "Las inscripciones medievales de la provincia de Huesca", Estudios de Edad Media de la Corona de Aragón, Zaragoza, 1967, pp. 32-34. Otras lecturas en A.K. Porter (1928, véase nota anterior) y Canellas y San Vicente, Aragon, p. 187. 
NE VRRACCA : IN ERA T ${ }^{A}$ : CENTESIMA X ${ }^{\mathrm{A}}$ EST EXPLICITA : REGNANTE REGE SANTIO RADIMIRIZ IN ARAGONE QVI POSVIT PRO SVA ANIMA IN HONORE S(AN)C(T)E MARIE : VILLA / N(OMI)NE LA / RROSSA VT DET EI D(OMI)N(U)S REQUIEM ET(ERNAM) / AMEN //

SCRIPTOR HARVM LITTERARU(M) N(OMI)NE AZENA MAGISTER HARV(M) PICTVRARU(M) N(OMI)NE GALINDO GARCEZ

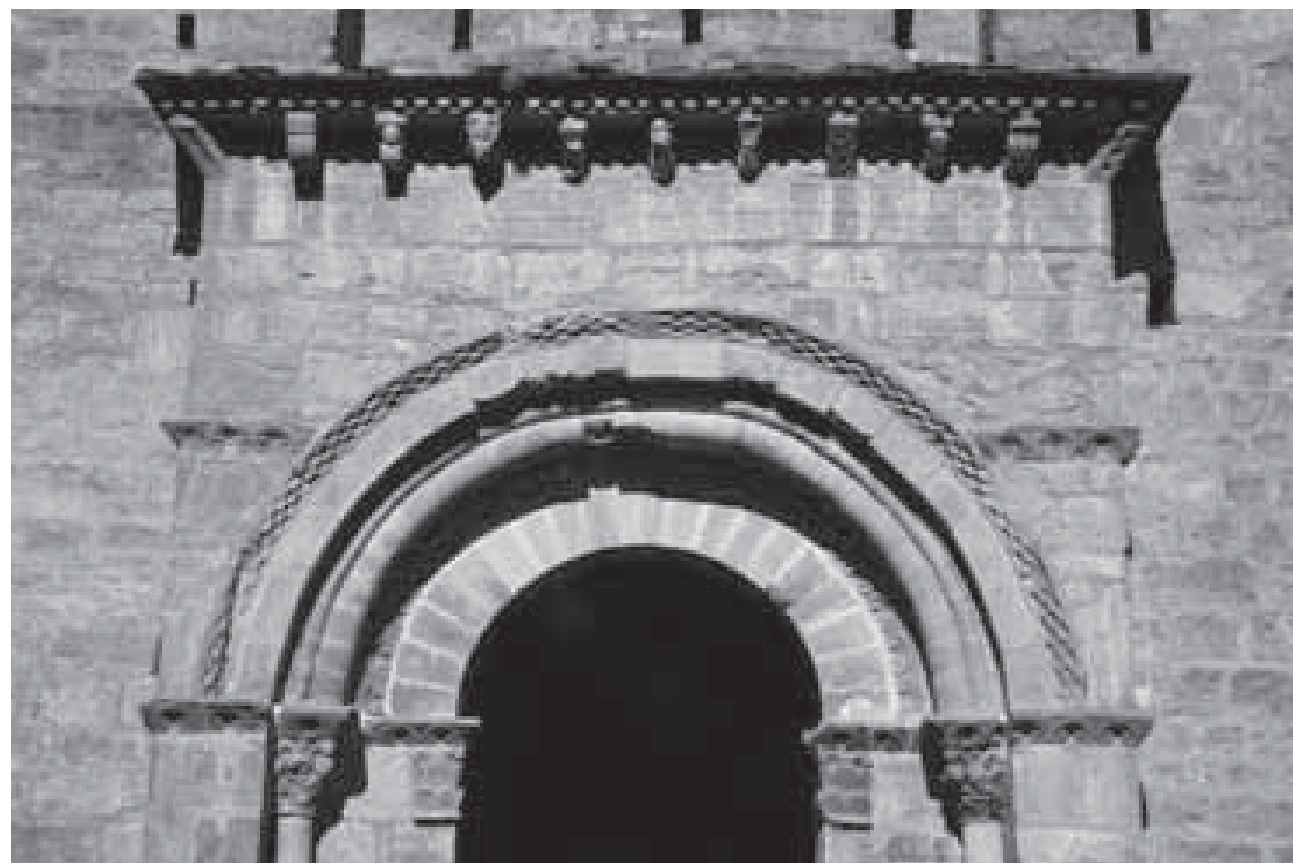

Fig. 17. Inscripción de la portada occidental de Santa María de Iguácel

Tres documentos confirman buena parte del contenido de la inscripción ${ }^{157}$. En el primero, el testamento de Sancho Galíndez y Urraca de 1063, aparece como destinataria privilegiada la iglesia de Sancta Maria de Ibuasar ${ }^{158}$. El segundo (llamado también testamento por su editor, aunque no es propiamente tal, sino una carta de donación de la iglesia de Iguácel con todas sus propiedades a San Juan de la Peña en 1080) nos informa de que Sancho y su esposa habían "reedificado" (reedificauimus: ¿refundado?, ¿reconstruido?) por remedio de su alma la iglesia de Juozare, que el conde había recibido de sus padres como bien alodial, y como "alodio de Dios" la entregan a San Juan de la Peña junto con otras propiedades en el día de la

157 "Threre is no monument in Spain more surely dated": W.M. WhitehILL, Spanish Romanesque Architecture of the Eleventh Century, Oxford, 1941, p. 243.

158 IbARra, Documentos, I, pp. 3-8. 
dedicación de la iglesia de la abadía ${ }^{159}$, ante la concurrencia de los reyes, el infante heredero, la familia de Sancho Galíndez, varios barones y el legado papal Frotardo, por lo que habremos de considerarla dote del nuevo templo ${ }^{160}$. Igualmente nos informa de que en beneficio de su alma, el propio rey Sancho Ramírez había donado a Dios y a Santa María la villa que se llama Larrosa, con todo lo que pertenecía al derecho regio ${ }^{161}$. La carta fue redactada por el escribano Isinarius, quizá el Acena que escribió "las letras" (scriptor harum litterarum) del epígrafe, como se viene suponiendo. El tercer diploma, un codicilo del conde elaborado en 1082 en previsión de una cercana muerte (in hora obitus mei) y después del fallecimiento de su cónyuge (uxore mea mortua), ratifica lo establecido en el primero, pero además solicita del abad de San Juan que dedique una parte de las rentas a construir el puente que él y su mujer deseaban realizar, y puntualiza algunos detalles de las mandas ${ }^{162}$.

La datación del epígrafe indicaría que la iglesia estaría terminada (explicita) "en la era centésima décima", equivalente al año $1072^{163}$. Pero si las obras jaquesas se iniciaron después de 1077, una relación modelo-copia sería inaceptable, puesto que la copia (Iguácel) dataría de fechas anteriores al pretendido modelo (Jaca). Así que la temprana

159 In die dedicationis eiusdem ecclesiae beato Joanni Babtistae (...) Facta carta donationis et confirmationis aere M. C. X. V. III. die dedicationis ecclesiae Sancti Joannis.

${ }^{160}$ In nomine Sancte et indiuidue Trinitatis. Ego Sancius Galindiz, una cum uxore mea domina Urracha, pro remedio animarum nostrarum, parentum atque filiorum nostrorum, reedificauimus ecclesia in honore omnipotentis Dei, et virginis Mariae, in loco vocitato Juozare. Hanc ecclesiam suprataxatam, ego praelibatus Sancius habui ad alodium ex parentibus meis; quam ecclesiam offero et dono et ad proprium alodium Dei libero omnipotenti Deo et Sancto Joanni de Penna, ad serviendum Deo sub ordine Sancti Benedicti: IBARRA, Documentos, L, pp. 135-142.

161 Et dominus noster gloriosus rex Sancius obtulit Deo et Sanctae Mariae pro anima sua villam quae vocatur Larrossa, cum omnibus quae ad regale ius pertinet. Completa la información relativa al segundo documento la carta de donación que hizo el rey a Sancho Galíndez, por la que le entregaba la villa llamada Larronsa, traducida por Salarrullana como Larrés, pero correctamente interpretada como Larrosa por Durán. El conde le había pedido que la pusiese al servicio de Santa María de Ibuaçele por el alma de Ramiro I y las de ambos intervinientes, y le dio trescientos sueldos de dineros (et dedistis mici precium in eam CCC solidos de dineros). Como curiosidad comentaré que es la carta de esta donación, firmada en la cuaresma de 1068, la que informa del viaje a Roma del monarca (quando ego pergebam ad Roma, in uilla que dicitur Aragueste): SAlarrullana, Documentos, III, pp. 7-8.

162 Pontem illum quem ego et vxor mea facere volueramus: IBARRA, Documentos, LVII, pp. 161-164.

163 He aquí la traducción de Durán: "Esta es la puerta del Señor por donde entran los fieles en la casa del Señor, que es la iglesia fundada en honor de santa María. Ha sido fabricada por mandato de Sancho conde junto con su esposa de nombre Urraca. Ha sido terminada en la era 1110, reinando el rey Sancho Ramírez en Aragón, el cual ofreció por su alma en honor de santa María la villa llamada Larrosa para que le dé el Señor la vida eterna amen. El escritor de estas letras se llama Acena. El maestro de estas esculturas se llama Galindo Garcez". La traducción de picturarum por esculturas ya fue propuesta por GómEz MorENO, El arte románico, p. 77, n. 3; nos daría el nombre del escultor principal. Otros autores han pensado que se refiere a pinturas murales que pudo haber en la fachada meridional. Cabrían otras interpretaciones. A partir de un juegodefotografíasincompleto(cosaqueélignoraba)J.CAROBAROJApropusounalecturaerróneadepartedelainscripción: "Santa María de Iguácel, su construcción y la inscripción conmemorativa de esta", Príncipe de Viana, XXXIII (1972), pp. 265-274. También E. Zudaire, "Inscripción de Santa María de Iguácel”, Príncipe de Viana, XXXV (1974), pp. 405-408. Advirtió el error S. MoralEJo Álvarez, "Sobre las recientes revisiones de la inscripción de Santa María de Iguácel”, Príncipe de Viana, XXXVI (1975), pp. 142-143. 
cronología de Iguácel y su aparente derivación de Jaca suponen un grave inconveniente para datar la catedral después de $1070^{164}$. Como advertía Moralejo, estamos ante una cuestión de gran calado relativa a la metodología de la Historia del Arte Medieval. ¿Qué debe prevalecer: las conclusiones basadas en un dato epigráfico o las obtenidas tras décadas de investigación rigurosa acerca del desarrollo de la escultura del Románico Pleno? En la toma de posición de cada investigador subyace la relevancia que le merecen las informaciones documentales frente a los análisis formalistas. Para quienes priorizan la aparente solidez de los datos contenidos en la inscripción y su respaldo documental, es un hecho firme que la iglesita de la Garcipollera estaba terminada en 1072. En caso de aceptar la derivación de Jaca, el modelo catedralicio debería haber sido ejecutado en los años sesenta. Era ésta la opinión de Porter y de la historiografía española anterior a 1960 (de "remedo uniforme de Jaca" la calificó Gómez Moreno ${ }^{165}$ ), pero también, con matices, es la de algunos especialistas de nuestros días ${ }^{166}$.

Otros estudiosos han intentado conciliar la datación epigráfica de 1072 con un inicio de las obras de Jaca en 1077. Durán Gudiol pensó que Iguácel no era la copia, sino "la primera manifestación del arte románico en el Alto Aragón, anterior a la iniciación de las obras de la catedral jacetana"167. Se trata de una opinión difícil de defender, dado el "aire de copias mediocres mucho más que de creaciones" apreciable en los relieves de Iguácel, en palabras de Gaillard ${ }^{168}$.

Mayor acogida ha tenido la hipótesis de la elaboración de Iguácel en dos o más fases. Esta idea ya había sido defendida por Canellas y San Vicente, quienes arguyeron su edificación en dos campañas, como indica la donación de 1080: la nave por una parte y la portada, ábside, columnas y capiteles por otra, a tenor de las diferencias de talla y disposición de materiales ${ }^{169}$. En una línea argumentativa paralela, Esteban, Galtier y García Guatas consideraron que Sancho Galíndez y Urraca habrían reconstruido una iglesia erigida hacia 1040-1050 por su padre el conde Galindo; la intervención de Sancho y su esposa, "esencialmente escultórica", habría consistido en la redecoración de la puerta, el ábside y las ventanas, y habría culminado en $1072^{170}$. Marcel Durliat se ha apoyado en la "dualidad" del edificio

164 Tras la limpieza de los capiteles de la cabecera, parece inaceptable la hipótesis de Gaillard, quien descartaba cualquier conexión con Jaca ("ni anuncian ni reproducen los bellos logros románicos de Jaca") y veía en Iguácel el "testimonio del repertorio tradicional en el que se produjo la eclosión de la escultura románica" relacionable en técnica y temática con el panteón leonés: G. GAILlARD, Les débuts de la sculpture romane espagnole Leon-Jaca-Compostelle, París, 1938, I, pp. 121-124 (en adelante: GAILlard, Débuts).

165 Gómez Moreno, El arte románico, p. 78.

166 Por ejemplo, I.G. BAngo Torviso, El románico en España, Madrid, 1992, pp. 148-157.

167 A. Durán Gudiol, Arte altoaragonés de los siglos Xy XI, Sabiñánigo, 1973, pp. 193-199.

168 Gaillard, Débuts, p. 123.

169 Canellas y San Vicente, Aragon, pp. 165-189. Recordemos que a estos autores no les resultaba problemática la dependencia de Jaca, dado que propugnaban para la catedral la cronología alta.

170 "Con soluciones arquitectónicas y escultóricas derivadas del arte que triunfaba en la corte jaquesa": Esteban, Galtier y García Guatas, Nacimiento, pp. 227-231 y 264-266. También estos autores son partidarios de un inicio de la catedral de Jaca en tiempos de Ramiro I, como ha quedado expuesto. 
para aseverar que lo terminado en Iguácel en 1072 era la arquitectura, mientras que el complemento escultórico habría sido añadido hacia $1094^{171}$.

Alcanzaremos una hipótesis sólida cuando hagamos coincidir los resultados de los análisis de las formas y sus significados con una interpretación plausible de las referencias escritas. Por ello voy a centrarme primero en la aparente veracidad del contenido de la inscripción y luego razonaré acerca de las formas empleadas en la arquitectura y en su complemento escultórico.

El examen detenido de los términos empleados en la exposición de la motivación del rey tal y como aparece redactada en la inscripción (qui posuit pro sua anima in honore Sancte Marie villa nomine Larrosa ut det dominus requiem eternam ${ }^{172}$ ) abre la vía de una nueva interpretación. Las colecciones documentales de Sancho Ramírez y Pedro I están llenas de donaciones cuyo expositivo emplea expresiones como ob remedium animee mee omniumque parentum meorum et omnium fidelium christianorum, o bien pro remissione omnium peccatorum meorum et pro animabus (sic) patris et matris mee omniumque peccatorum meorum, o también pro salute et remedio anime mee, etc. En los documentos de ambos soberanos la referencia a la remisión de los pecados se usa siempre en primera persona (peccatorum meorum); en cambio la redención del alma se aplica a uno mismo y a otras personas (pro redemptione anime mee et patris mei et matris mee). A la hora de hablar de los difuntos siempre se indica que se hace directamente por el alma (pro anima) o por su curación, salvación o redención (remedium, redemptione, salute). Pero en ninguna donación referida a un personaje vivo se habla de que Dios le conceda el descanso (requiem [eternam]) como figura en el epígrafe. En cambio, tal expresión aparece continuamente asociada a los difuntos: ...pater meus, cui sit requies (sucede lo mismo con la expresión bone memorie). Y es especialmente frecuente en los diplomas de Pedro I. Hasta en catorce ocasiones aparece cui sit requies en la colección diplomática de Pedro I y siempre con este sentido, aplicada a su progenitor difunto. También en la inscripción de la puerta de Loarre la fórmula vt donet illi requiem serenam se aplica al difunto Tulgas ${ }^{173}$. Ante este hecho cabe preguntarse si realmente la inscripción fue redactada y ejecutada en vida de Sancho Ramírez, o bien se realizó después de 1094, con lo que dejaría de existir el problema cronológico con respecto a la catedral de Jaca. En tal caso, la obra de Iguácel se acercaría a otro

171 M. Durliat, La sculpture romane de la route de Saint-Jacques. De Conques à Compostelle, Dax, 1990, pp. 253-254.

172 La palabra eternam no se lee ni cabe completa en el espacio para ella asignado. El sillar está muy deteriorado en esa zona y las letras del final no se distinguen. Porter transcribió eum, pero aparece con anterioridad el dativo $e i$, de modo que no tendría sentido un segundo pronombre. La expresión del oficio de difuntos es: Requiem eternam dona eis Domine. La expresión Requiem eternam det ei Dominus aparece en composiciones musicales. Posiblemente para eternam se empleó una abreviatura, como en otras palabras de la inscripción.

173 La lectura correcta de la inscripción en W.M. WhitehiLL, “An inscription of 1095 at Loarre”, Speculum, III (1928), p. 254. 
edificio comparable por dimensiones y formas escultóricas, aunque un poco más modesto, San Adrián de Sasave, antigua sede episcopal cuya reconstrucción fue consagrada en 1104 y cuya vinculación con la catedral de Jaca ha sido estudiada por David Simon ${ }^{174}$.

Tal interpretación no se concilia con el texto de la inscripción, no sólo porque éste especifica la terminación en 1072, sino también porque postula su realización en vida de Sancho Ramírez. Cabría cuestionar si se produjo un fallo relativo al año, debido a que el incisor (¿Galindo Garcés?) se equivocara al pasar a piedra el texto del redactor Acena. Sabemos que cometió otros errores, que llevaron a la colocación de palabras fuera de la caja, uno tan importante como el nombre de la localidad donada por Sancho Ramírez (en el espacio pautado se lee Villarrosa y al colocar encima nomine la queda transformada en villa nomine Larrosa; también la palabra amen final tuvo que ubicarse fuera de la pauta). Quizá Aznar escribió letras enlazadas en minúscula visigótica, que tantos problemas de lectura causó, como ha descrito en repetidas ocasiones Ubieto Arteta.

Queden estas reflexiones como una línea de investigación abierta, ya que no consigo conciliar la impresión acerca del carácter retrospectivo de la inscripción con la afirmación de que la obra fue terminada bajo el reinado de Sancho Ramírez, a quien el propio texto parece referirse como difunto. Sólo si la inscripción hubiera sido añadida después de concluida la iglesia podría casar todo lo aquí expuesto. La inclusión de piezas verticales entre los sillares segundo y tercero, y cuarto y quinto lleva a pensar que las letras fueron talladas antes de ser colocado su soporte, a fin de que el friso con la inscripción alcanzara la anchura final de la portada ${ }^{175}$. La inscripción lateral, la que se refiere al escritor y al autor de las picturae parece ejecutada con menos cuidado, quizá después de colocados los sillares. Cabe imaginar circunstancias para casar todos los datos, pero son conjeturales ${ }^{176}$.

El análisis de la materialidad del templo y de las formas empleadas en sus relieves proporciona informaciones valiosas. En primer lugar, en cuanto a la hipótesis de las dos campañas, coincido con la opinión del arquitecto que restauró la iglesia en los años setenta y ochenta del pasado siglo, Antonio Almagro, quien no encontró evidencias de que el edificio hubiera sido ejecutado en dos fases (una estructural

174 La noticia de la consagración en $C D C H$, doc. 90, pp. 114-116, que el editor fecha entre 1100 y 1104. Las relaciones de su escultura con Jaca e Iguácel fueron estudiadas por D.L. Simon, "San Adrián de Sasave and Sculpture in Altoaragón", Romanesque and Gothic: Essays for George Zarnecki, Woodbridge, 1987, pp. $179-184$.

175 Lo apreció A. Almagro Gorbea, "Restauraciones en el Románico oscense: La Iglesia de Santa María de Iguácel”, Artigrama, 6-7 (1989-1990), pp. 49-79, especialmente p. 53.

176 Por ejemplo, podríamos suponer que la inscripción fue redactada por Azena cuando Sancho Galíndez y Urraca mandaron renovar la iglesia, quizá en 1072, pero la obra no fue emprendida hasta años después, con lo que en el momento en que Galindo Garcés (o un escultor desconocido) grabó el texto, Sancho Ramírez ya había muerto y lo único que se modificó de la redacción original fue la expresión referente al monarca. Hipótesis ingeniosas como esta son gratuitas por indemostrables. 
y otra en que se hubiera aplicado la ornamentación escultórica, o bien una en la que se elevara la nave y otra en que añadieron ábside y portada occidental ${ }^{177}$. Casi todos los elementos que incluyen escultura (ventanas) están perfectamente trabados con los muros adyacentes y parece evidente que la arquería interior no hubiera podido introducirse en un ábside ya construido sin causar trastornos en la fábrica inicial perceptibles a través de empalmes de obra. Sin embargo, el resalte de la portada no está trabado con la misma perfección, lo que podría llevar a pensar en que dicha portada sí hubiese sido añadida tras haber sido terminado el resto del edificio. De todas formas, los elementos escultóricos de la portada participan de las mismas pautas formales que los de las ventanas y la arquería absidal, por lo que no es defendible una ejecución muy posterior de la puerta, en todo caso un montaje final a partir de elementos ya preparados.

En segundo lugar, varios elementos sólo son explicables en caso de que Iguácel derive de Jaca. No me entretendré en los nexos ya planteados con respecto a los capiteles historiados, que no convencieron a Durán, sino en detalles de evolución de motivos que permiten conclusiones verificables. Primero, la moldura ajedrezada que corta a media altura las enjutas de la portada de la iglesia de la Garcipollera. Acierta García Omedes cuando la hace derivar de la portada de Jaca, donde su presencia es perfectamente coherente con la composición de los exteriores, ya que da continuidad a la moldura que recorre en horizontal la fachada meridional ${ }^{178}$. En cambio, en Iguácel no tiene otra razón de ser que la copia. Y en segundo lugar, en Iguácel, como en Sasave, las palmetas inscritas de los cimacios de los capiteles adoptan un particular diseño, ya que se enlazan dos a dos gracias a la prolongación del bucle inferior de los arcos que las envuelven. La palmeta inscrita es el tema por excelencia en la decoración de cimacios en Saint-Sernin de Toulouse y fue empleada en casi todos los edificios que de allí derivan. Pero en Toulouse en ningún caso se da esta atípica manera de enlazarlas por parejas. Estaríamos ante un ejemplo más de degradación de temas representados en Jaca y copiados en Iguácel. Otro caso muy evidente es la figura desnuda entre hojarasca del arco septentrional de la arquería absidal de Iguácel, remedo del que soporta el arco de acceso al transepto desde la nave meridional de la catedral jaquesa ${ }^{179}$. La paradoja va todavía más lejos: de aceptarse la cronología de Iguácel en 1072, las palmetas tolosanas habrían sido creadas antes en Iguácel que en Tolosa (conforme a las fechas generalizadamente admitidas), lo que sería un sinsentido, porque es evidente que en Iguácel el motivo está degradado. Por último, la moldura quebrada que recorre el muro sur, lejos de

177 A. Almagro Gorbea, "Restauraciones en el Románico oscense: La Iglesia de Santa María de Iguácel”, Artigrama, 6-7 (1989-1990), pp. 49-79, especialmente pp. 52, n. 2 y 63.

178 A. García Omedes, "Portadas: el triunfo de un modelo o la necesidad de cambiar para uniformar", http://www.romanicoaragones.com/Colaboraciones/Colaboraciones04337Portadas1.htm.

179 Este concreto tema todavía tuvo un grado mayor de degradación cuando el esquema de Iguácel inspiró un capitel de la capilla mayor de Santa María de Ujué en Navarra. 
ser un rasgo propio de la tradición anterior al Románico Pleno, es en realidad característico de la catedral de Jaca (la moldura que recorre el muro meridional y occidental por el exterior y el interior presenta quiebros en función de la distribución de vanos) y sus secuelas (la vemos en el interior de los ábsides de Ujué).

Para resumir mi punto de vista, nos encontramos ante una contradicción entre lo que inferimos de los textos y lo que nos indica el análisis de la materialidad de la obra ${ }^{180}$. En los textos, concretamente en el epígrafe, topamos con una expresión (ut det Dominus requiem eternam) que resulta contradictoria con la fecha de ejecución allí escrita. En cambio, en el análisis de la materialidad, en el estado actual de nuestros conocimientos, nada contradice la evidencia de que Iguácel deriva de Jaca y Jaca, a su vez, de Toulouse. Por otra parte, hemos visto que los textos en que descansaba la cronología antigua de Jaca estaban falsificados, mientras que el análisis de la materialidad del edificio catedralicio nos lleva a una datación posterior a 1076. Con estos datos, es muy difícil admitir que Iguácel tal y como la vemos pudiera estar terminada en 1072. Por tanto, o bien hay que interpretar de otro modo la palabra explicita, quizá referida no a la conclusión de la materialidad del edificio, sino a la exposición o manifestación pública del deseo de construirlo por parte de Sancho Galíndez, o bien se cometió un error en la redacción del texto o en su posterior transcripción para la incisión, o estamos ante un epígrafe retrospectivo en el que voluntaria o involuntariamente se deslizó un dato erróneo.

\section{Construcciones religiosas: las razones del rey}

La catedral de Jaca constituye la obra cumbre de un conjunto de edificios religiosos de enorme interés y trascendencia para el arte románico peninsular, en los que la intervención de Sancho Ramírez y sus hijos se acusa de manera directa o indirecta.

Existe consenso a la hora de atribuir al monarca la promoción de la gran iglesia de Loarre, con base en el privilegio papal de 1071 (que refleja la constitución allí de un monasterium a cargo de un prepósito) y en el testimonio referente a la creación de una canónica antes de junio de 1074 (a la que el rey habría dado el monasterio de Fanlo con sus pertenencias) ${ }^{181}$. Su amplia nave única, su esmerada articulación interna, su atrevido cimborrio de notable perfección e innovación, y la singularidad de su programa ornamental han sido vistos como la más evidente plasmación de una arquitectura

180 Habría nuevos argumentos a añadir, en lo referente a las dimensiones del templo, pero para alcanzar conclusiones al respecto necesitaría desarrollar un planteamiento renovador completo acerca de las construcciones de la Jacetania de carácter rural, para el que no dispongo de espacio. Quede para una ulterior publicación.

181 El privilegio papal fue publicado por KeHr, Papsturkunden, doc. 3, su autenticidad ha suscitado dudas, pero su contenido se tiene por verosímil como hemos expuesto en la nota 98. La creación de la canónica en Salarrullana, Documentos, XI. 
propagandística del poder de la monarquía aragonesa frente a sus enemigos andalusíes asentados en la fortaleza vecina de Bolea y en la deseada ciudad de Huesca ${ }^{182}$. Loarre era la más magnífica y compleja entre las fortificaciones del reino de Aragón previas al reinado de Sancho Ramírez, quien pudo sentirse impelido por ello a promover allí un edificio singular, portador de significados a través del complemento escultórico y muy probablemente de determinadas formas arquitectónicas. Marta Poza ha propuesto recientemente, como referencia cronológica que marcaría el final de las obras, una hipotética consagración en 1094, tomando como argumento la reunión en el castillo de tres obispos y abades, junto al monarca ${ }^{183}$. No creo casual que la Crónica de San Juan de la Peña coincida en el mismo año a la hora de concretar su edificación por parte del soberano: "En el anno de M XCIIII priso Nabal et el Pueio don Sancho sobre Huesca et hedificó el castiello de Marcuello et de Loarre et Alquezar"184. Las relaciones cruzadas entre Loarre, Jaca, Frómista y Toulouse, expuestas con mayor o menor profundidad por la historiografía, invitan a un estudio integral que se intentará abordar en el ya citado proyecto de investigación. Desde la óptica de esta ponencia, sería fundamental establecer en qué momento se planteó y acometió la edificación del templo, a fin de valorar su contemporaneidad con respecto a la construcción de la seo jaquesa y su lugar en la trayectoria de las empresas artísticas del monarca.

No existe consenso, en cambio, a la hora de definir la participación del rey en las obras de la iglesia alta de San Juan de la Peña. El repaso de la documentación regia acredita la presencia de Sancho Ramírez en el cenobio pinatense en los meses de febrero, marzo o abril al menos durante dieciocho de sus treinta años de reina$\mathrm{do}^{185}$, lo que demuestra que era lugar predilecto para pasar la cuaresma, tiempo fuerte por excelencia en el año litúrgico cristiano, previo al comienzo de las campañas guerreras primaverales. San Juan era al mismo tiempo cementerio de sus padres y antepasados, donde él mismo había previsto su entierro ${ }^{186}$. La participación del so-

182 PozA, "Fortaleza", pp. 78-81; MANN, Romanesque, pp. 125-129. Sobre el programa escultórico de la portada es imprescindible la reciente aportación de F. EsPaÑOL, "El castillo de Loarre y su portada románica", Locus Amoenus, 8 (2005-2006), pp. 7-18.

183 Poza, "Fortaleza", p. 72.

184 C. Orcástegui Gros (ed.), Crónica de San Juan de la Peña (Versión aragonesa) Edición crítica, Zaragoza, 1986, p. 38.

185 Concretamente durante los años 1062, 1063, 1066, 1067, 1068, 1069, 1070, 1077, 1079, 1080, 1081, 1083, 1084, 1087, 1088, 1089, 1090, 1092, 1093 y 1094: D.J. Buesa Conde, Sancho Ramírez, rey de aragoneses y pamploneses (1064-1094), Zaragoza, 1996, pp. 219-221 ("Itinerario real").

186 Quoniam idem monasterium est locus sepulturae mee et parentum meorum: SALARRULlana, Documentos, VIII (1074; la cita del obispo García en Jaca pone en duda la autenticidad del diploma); Quia, igitur, ibi sunt humata corpora auorum et parentum meorum et ego atque omnis mea posteritas ibi sumus sepeliendi: SALARRULLANA, XVIII (1081). Este diploma en el Libro Gótico recibe una redacción diferente, en lo que parece una interpolación por la que Sancho Ramírez obligaría a todos sus descendientes a enterrarse en San Juan: quod corpus meum iubeo tumulari iusta corpus patris mei regis Ranimiri; et mando ut omnes fili mei et omnis posteritas mea ibi sepeliantur; et rogaui totos nobiles Aragonenses, ut ipsi, propter amorem Dei et propter seruicium Ihesu Xristi, quod ibi fit iugiter et propter meum amorem ibi haberent sepulturam. No parece casual que a partir de esas fechas empiecen a multiplicarse las noticias funerarias protagonizadas por nobles del entorno del soberano en el monasterio pinatense. La monumentalización del 
berano solemnizó celebraciones de enorme relevancia: el cambio de rito (1071), las sucesivas dedicaciones de altares (1080 y 1094), el traslado de los restos mortales de su padre $(1083)^{187}$, la recepción de las reliquias de San Indalecio $(1084)^{188}$, etc. Sin embargo, ni los numerosos diplomas pinatenses en los que se menciona al monarca, ni las crónicas posteriores han dejado memoria de una intervención directa del rey en la financiación de las obras, lo que tampoco significaría una falta de colaboración, bien por la hipotética edificación gracias a rentas generadas por donaciones de bienes inmuebles ${ }^{189}$, bien por la muy probable entrega de cantidades en metálico que no han dejado rastro documental. El problema radica en la interpretación de ciertos elementos que conforman la iglesia alta, puesto que mientras se ha visto la relación con Jaca y Loarre de algunos capiteles de la cabecera, en cambio se han barajado interpretaciones contrapuestas para la nave única y para la puerta de comunicación con el claustro. También aquí será preciso profundizar en los análisis formales y en la contextualización de acontecimientos históricos a fin de dirimir en qué medida el soberano fue colaborador o protagonista de la empresa constructiva.

En cuanto a Siresa, aunque el privilegio de 1082 evidencia el interés de Sancho Ramírez por el cenobio, quod monasterium est regalis capella ${ }^{190}$, el análisis de las

panteón regio no debe ser separada de la elección de San Juan de la Peña como lugar preferente de enterramiento por los nobles aragoneses. Las inscripciones del panteón y del claustro, así como los testamentos conservados, evidencian que en el reinado de Sancho Ramírez se produjo un generalizado interés de los barones que acompañaban al monarca por enterrarse en San Juan, de lo que se derivaba la donación de propiedades y rentas. El epígrafe más antiguo relativo a un noble data de 1082 (Fortún Blázquez y Jimena), seguido por el de Fortún Íñiguez (1089) y Lope Garcez (1091); los restantes son ya del siglo XII. Entre los abades, el epígrafe funerario más antiguo corresponde al abad Aquilino (1075), seguido del de Sancho (1085): A. Durán Gudiol, "Las inscripciones medievales de la provincia de Huesca", Estudios de Edad Media de la Corona de Aragón, 8, Zaragoza, 1967, p. 65 para el listado de inscripciones; la transcripción de las mismas en pp. 78-86. También el panteón de nobles es una creación arquitectónica y escultórica que merece estudio más profundo del que hasta ahora ha recibido.

187 En 1082, pocas semanas después de la conquista de Graus, tuvo lugar el entierro definitivo de sus restos (quando sepeliui de nuo patrem meum et matrem in eodem monasterio, quarta decima die postquam Deus dedit michi Gradus: Salarrullana, Documentos, XXI), momento en que hizo la donación del castillo de Ayerbe. A autores como Antonio Ubieto no ha escapado la cercanía de ambos acontecimientos, como si Sancho Ramírez hubiera querido dar descanso final a su padre una vez conquistada la localidad en cuyo asedio había fallecido Ramiro.

188 El relato del traslado de las reliquias no concede protagonismo al monarca, que estuvo presente en la ceremonia de recepción de los restos el jueves santo 28 de marzo de 1084 . Fue escrito a petición del abad pinatense por un monje cluniacense, de nombre Hebrethme, testigo de la solemne ceremonia de recepción de los restos: A. Durán Gudiol, "El traslado de las reliquias de san Indalecio a San Juan de la Peña", Argensola, 109 (1995), pp. 13-24. LaLiena, "Encrucijadas", p. 299, no duda que Sancho Ramíez "hizo recuperar el cuerpo de san Indalecio en Urci (Almería)". Proporcionará luz al respecto el estudio de este traslado en paralelo a otras recepciones de reliquias en décadas cercanas, como las de San Isidoro en León tras la intervención de Fernando I o el pío latrocinio de Braga que tuvo como beneficiaria la sede compostelana. Muy posiblemente la contextualización adecuada para comprender este acontecimiento deba incluir el hecho de que san Indalecio represente una tradición de cristianización de la península ajena a la presencia de Santiago (por lo que juega también en el tablero de actuaciones tendentes a oponerse al predominio leonés).

189 Un resumen y valoración de las donaciones de Sancho Ramírez en A.I. LAPEÑa PAúl, El monasterio de San Juan de la Peña en la Edad Media (desde sus orígenes hasta 1410), Zaragoza, 1989, pp. 66-69.

190 Canellas, Colección, doc. 57. 
soluciones aplicadas en cabecera y transepto (dimensiones de las naves longitudinal y transversal, trazado exterior poligonal e interior semicircular de la cabecera, articulación plástica de los paramentos internos mediante arcos ciegos en dos niveles, desornamentación ajena a la monumentalización constructiva, etc.) me lleva a pensar que no se realizaron durante el reinado de Sancho Ramírez, puesto que no participan del repertorio utilizado en las obras hasta ahora estudiadas, sino de un estadio a mi juicio algo más tardío de la evolución del Románico. El aparejo sería el único referente vinculable con el siglo XI, pero no debemos olvidar que su principal rasgo es el de la rusticidad, no el de una opción propia de una corriente arquitectónica formalmente definida. Como en los dos casos anteriores, el proceso constructivo exige estudio minucioso, que está previsto acometer en el futuro.

¿En qué medida afectaron a Loarre, San Juan de la Peña o Siresa los acontecimientos de 1076? Es una cuestión abierta, puesto que, a diferencia de lo que hemos visto en Jaca, ningún estudioso ha dado importancia a ese año con respecto a dichas fábricas. Quede pues su consideración para otra ocasión, dada la excesiva extensión que está alcanzando este texto. En cambio, sí será conveniente comentar siquiera brevemente que la aceptación de Sancho Ramírez como titular del reino de Pamplona por parte de la fortaleza de Ujué ese mismo año sí parece haber sido factor determinante en la renovación de la arquitectura de su iglesia de Santa María ${ }^{191}$. Del edificio románico queda la cabecera, constituida por tres ábsides escalonados más un tramo de nave delante de cada uno (fig. 18). El vínculo entre la ornamentación de Ujué y la catedral de Jaca ya había sido señalado desde mediados del siglo pasado por historiadores que se fijaron en las molduras ajedrezadas ${ }^{192}$. Marcel Durliat añadió la dependencia de sus capiteles con respecto a la seo altoaragonesa, en lo que consideraba el estadio último de degradación de las fórmulas jaquesas (y de ahí derivaba una datación tardía) ${ }^{193}$. En publicaciones previas he llamado la atención sobre las relaciones igualmente cercanas con Jaca en lo arquitectónico ${ }^{194}$. Un reciente análisis más pormenorizado ha permitido concretar que todos y cada uno de los temas que vemos en los capiteles tienen su antecedente en la catedral o en iglesias de su entorno (especialmente Iguácel y Sasave); asimismo, que

191 En un documento de concesión de exenciones a los habitantes de Ujué el rey agradece la "buena voluntad" y el "gran servicio" que le habían ofrecido. ¿En qué habían consistido? El texto llegado a nuestros días no lo especifica, pero al parecer sí una copia del privilegio que manejó Moret, quien expone que el soberano lo hizo "porque vosotros fuisteis los primeros que me reconocisteis por vuestro señor y rey en aquella entrada de Pamplona y me entregasteis el castillo": J. DE Moret, Anales del reino de Navarra. Edición anotada e índices dirigida por: Susana Herreros Lopetegui, Pamplona, 1989, vol. III, nº 668 (p. 490).

192 J.M. Lacarra y J. Gudiol, "El primer románico en Navarra. Estudio histórico arqueológico", Príncipe de Viana, V (1944), pp. 242-243. Las grandes escocias de las basas constituían a ojos de Gudiol otro innegable nexo de conexión con la catedral jaquesa; sin embargo, le parecían más determinantes los vínculos arquitectónicos con Leire.

193 M. Durliat, La sculpture romane de la route de Saint-Jacques. De Conques à Compostelle, Montde-Marsan, 1990, pp. 244-245.

194 En contraposición a la idea insostenible, cuando se analizan uno a uno los elementos constructivos empleados, de que Ujué era secuela directa de Leire. Los elementos de origen legerense son mucho menos significativos que los jaqueses. 


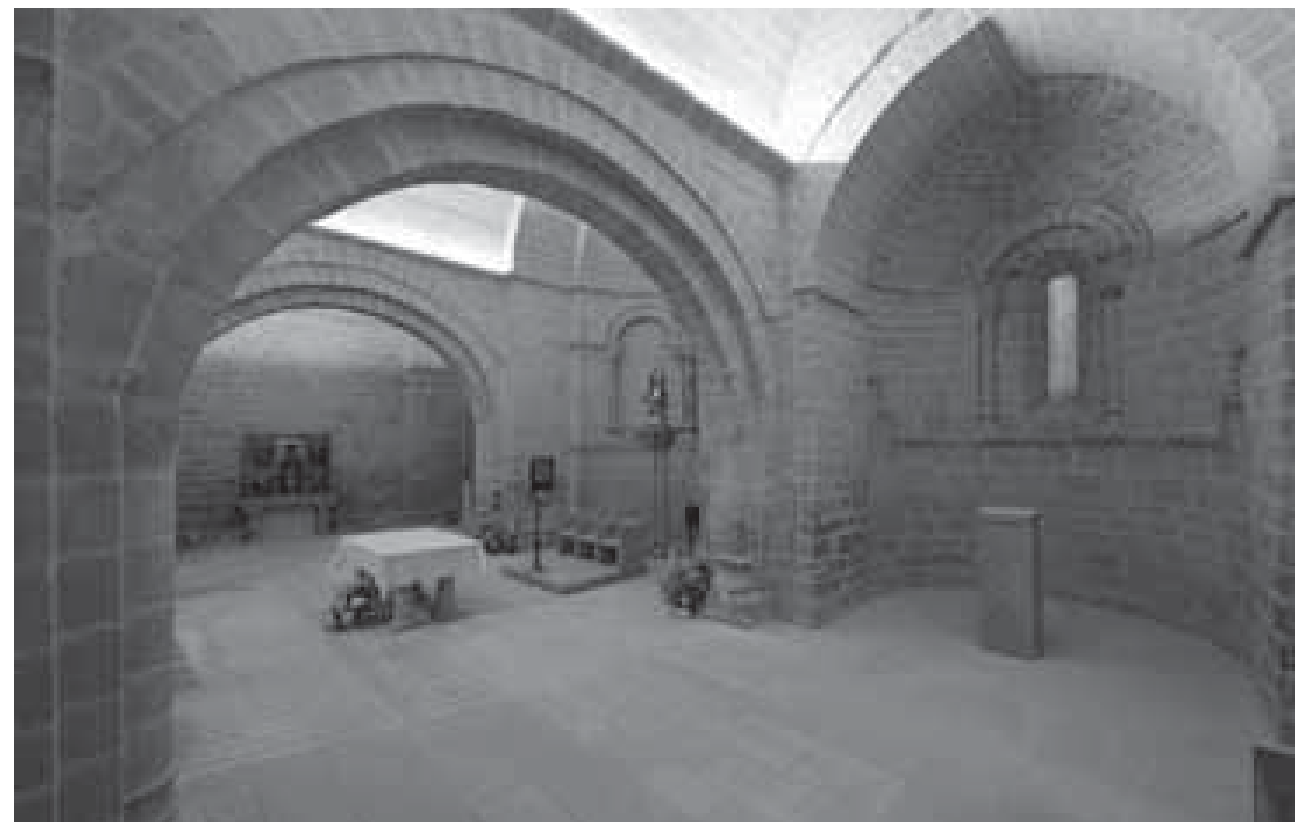

Fig. 18. Cabecera románica de Santa María de Ujué (Foto Luis Prieto).

existen otros recursos arquitectónicos venidos de Aragón (la ventana cruciforme que encontramos en el muro occidental del ábside septentrional, reabierta en la reciente restauración) y que muy probablemente es de inspiración legerense la ausencia de transepto, acorde con las dimensiones mucho más modestas de Ujué ${ }^{195}$. Excavaciones muy recientes han localizado bajo el presbiterio ujuetarra una construcción previa, consistente en una cabecera con tres capillas de remate recto, fechada-mediante el análisis de un enterramiento que apareció bajo uno de los muros- con posterioridad al año mil. Sobre ella se alzó a finales del siglo XI el nuevo templo. El hecho de que la construcción de una gran nave gótica en el siglo XIV implicara la excavación de la roca sobre la que se asienta la iglesia, impide conocer de qué modo se prolongaba hacia el Oeste la cabecera del Románico Pleno. Los anteábsides de las tres capillas tienen la misma profundidad, como tuvieron los de la catedral de Jaca, y la distribución de molduras y arcos coinciden en la derivación de Jaca, por lo que hemos de pensar en que la fase románica de Santa María de Ujué fue construida por un maestro modesto que venía de la seo aragonesa, cuyas incorrecciones lo relegarían a un puesto secundario en el organigrama del taller jaqués.

Ujué aporta un dato cronológico de gran valor. Un documento de Sancho Ramírez expone que hacia 1086-1089 estaba en construcción por su voluntad: Similiter

195 J. Martínez de Aguirre, “Arquitectura medieval”, en VV. AA., Santa María de Ujué, Pamplona, 2011, pp. 62-76. 
placuit nobis uolenti animo et spontanea uoluntate et edificamus ecclesiam beate Dei Genitricis Marie in Uxue ${ }^{196}$. No podemos saber si se encontraba por entonces en fase de proyecto, de cimentación, de ejecución de muros o de cierre de bóvedas. Pero está claro que para esas fechas se había iniciado el proyecto de Jaca, puesto que Ujué lo copia en el diseño de la cabecera y en el repertorio temático de los capiteles. Es imposible afinar más, porque desconocemos los ritmos constructivos de Jaca, Ujué e incluso de Iguácel (algunos de cuyos capiteles y basas parecen fuente más inmediata de los diseños ujuetarras que los correspondientes de Jaca). Como cabe imaginar distintos escenarios de progresión más o menos simultánea de estos tres edificios, no merece la pena especular aquí al respecto.

Las peculiares connotaciones de manifestación de la realeza discernibles en Jaca, Loarre o Ujué enriquecen las motivaciones habituales en cualquier gran empresa arquitectónica religiosa de la época. El diploma tantas veces citado referente a la reforma de la vida canonical en Jaca, expone con claridad que las donaciones de los fieles a las iglesias generalmente perseguían el perdón de los pecados, conforme al principio veterotestamentario de que las limosnas limpian los pecados (Si 3, 30). Ésta razón basta para justificar las donaciones de los monarcas y los particulares a monasterios e iglesias. Nuestra cultura contemporánea tiende a diferenciar actuaciones públicas y privadas, religiosas y profanas, que en el pensamiento premoderno eran inseparables. Para quienes tenían una visión trascendente del mundo acorde con el pensamiento cristiano, la prioridad de la salvación del alma y la intervención efectiva de Dios en los asuntos terrenales eran principios básicos de su fe. En este sentido, Sancho Ramírez participaba de las preocupaciones generalizadas en su época, entre las que sobresalía el temor ante el destino en el más allá, la muerte segunda de la que habla la inscripción del tímpano de Jaca. Una donación a San Juan de la Peña de 1069 lo expresa con claridad: Hec est scedula quam facio ego Sancius, gratia Dei rex, preuidens extremitatem dierum meorum expauescensque geenam desideransque celica regna, posui ad Sanctum Ihoannem, ubi est spes ac fiducia mea, unum domicilium qui dicitur Sanctum Fructruosum de Senes ${ }^{197}$. Es uno más entre los numerosos diplomas que recuerdan el temor de Dios (compunctus Dei timore ${ }^{198}$ ) y la incertidumbre acerca del destino del alma en el más allá, al tiempo que solicitan la remisión de los pecados (in remissionem omnium peccatorum meorum), la salvación del alma propia y de las de sus padres (pro remedio animae meae et omnium parentum meorum), contando con la intercesión de

$196 \mathrm{Su}$ fecha es problemática. En la edición más reciente, Barrios Martínez lo data el 13 de enero de 1086, conforme al texto, pero advierte que en enero de ese año era todavía obispo de Jaca el infante García, y no Pedro, que es quien figura en la cláusula correspondiente (Alius episcopus Petrus in Iacha).

197 Salarrullana, Documentos, V (año 1069). En la misma línea: ego Sancius, gratia Dei rex, compunctus Dei amore et expauescens pauendum terrorem, ob amorem, scilicet, Beati Babtiste Iohannis: SALARRUllana, Documentos, XXIV (1085): Ego Sancius, gratia Dei Aragonensium rex, compunctus Dei amore et perterritus peccatorum meorum timore: Salarrullana, Documentos, XXVI (1085).

198 Salarrullana, Documentos, VIII (1074) y XXXI (1087). 
los santos (ut Sanctus Iohannes et omnes Sancti Dei sint intercessores ad Dominum Ihesum Xristum pro nobis ${ }^{199}$ ).

Junto a ello, las cláusulas relativas a las motivaciones de las donaciones regias aragonesas no pueden ser más elocuentes en la presentación de la dimensión terrenal de la ayuda divina. Como otros monarcas de su época ${ }^{200}$, los aragoneses consideraban que era el propio Dios quien les daba la victoria sobre los enemigos, quien les entregaba castillos y poblaciones, quien confirmaba su realeza ${ }^{201}$. Sancho Ramírez reconoció que Dios le había entregado Castro Muño, Monzón, Arguedas, etc. ${ }^{202}$ Cuando en 1072 emprendió la conquista de la fortificación de Graus, donde su padre había encontrado la muerte, prometió una magna donación al monasterio de San Victorián que se materializaría en el momento en que Dios le concediera la victoria y confió en que San Victorián intercedería por él y Dios le confirmaría su reino $^{203}$. Este instrumento es paradigmático de la concepción feudal que tenía el rey acerca de sus relaciones con los habitantes del Cielo, así como de su convencimiento acerca del poder de intercesión. No es el único diploma que muestra hasta qué punto Sancho Ramírez consideraba las donaciones a las instituciones eclesiásticas como una suerte de pacto, un do ut des del que derivaría la consecución de sus expectativas terrenales y la vida eterna, como confirman las cartas relativas a Santa Cruz de la Serós y Montearagón ${ }^{204}$.

199 Salarrullana, Documentos, XV (1077).

200 A. Isla FreZ, Memoria, culto y monarquía hispánica entre los siglos X y XII, Jaén, 2006, pp. 84, 89 y 91; LALIENA, "Encrucijadas", pp. 308-309 y ss.

201 La donación a la iglesia de San Andrés Apóstol de Roda y a su obispo Raimundo Dalmacio se hace por su salvación y por la estabilidad del reino: dono ab integrum et in perpetuum concedo Deo et sancto Andree ut sanctus Andreas sit michi propicius et intercedat ad Deum et dominum nostrum pro anima mea et animabus patris et matris mee omniumque fidelium christianorum et pro stabilitate totius regni nostri et pro salute omnium nostrorum: CANELLAS, Colección, doc. 143.

202 Anno quando dedit Deus castro Munnionis ad christianos; in castro Muniones quando Deus dedid illum ad christianos: CANELlas, Colección, docs. 39, 40, 55. 1086: Hec est carta quam facimus ego Sanctius Dei gratia Dei simul cum filio meo Petro Sanctii, uobis homines de Estatella quod posuistis animas uestras ad seruitium Dei et fidei Hispaniae ut Ihesus Christus dominus noster simul cum suis sanctis donauit nobis Montsone: Canellas, Colección, doc. 88. Ecclesias autem sancti Iacobi et sancte Marie de Chalamera et ecclesiam de Fraga et de Çaidin et de Oso et de Silcena et Urencia et de Albalat et de Calauera et Arrasal [quando Deus] dederit in manus christianorum sint iuris supradicti episcopi; usque ad diem illum quod Deus dedit mihi castrum Monnionis et alium quod dicitur Arguedas: CANELlas, Colección, doc. 115.

203 Si aliquando daret mihi Deus castrum de Gradus, darem illud sancto Uictoriano (...) pro anima patris mei et matris mea et pro anima mea omniumque parentum meorum et ut Sanctum Victorianum intercedat pro me ad Deum et ut Deus corroboret regnum meus: CANELlas, Colección, doc. 23.

204 Donación a Santa Cruz de la Serós de la capilla de Santa Cecilia de Aibar (1074): Et hec mea oblacio acceptabilis sit Deo, quatenus donet mihi Deus uictoriam contra innimicos nominis Christiani, et de isto regno transitorio ualeamus transire ad regnum celestis gaudia (CANELLAS, Colección, doc. 30). Donación a Montearagón (1093): Et hec nostra oblatio acceptabilis sit Deo, quatenus det nobis Deus uictoriam contra inimicos nominis christiani et de isto regno transitorio ualeamus transire ad regni celestis gaudii, et in die tremendi examinis mereamur in electorum numero aggregari atque audire illam desiderabilem et optabilem uocem: Uenite benedicti Patris mei, percipite regnum quod uobis paratum est ab origine mundi (CANELLAS, Colección, doc. 137). 
Es muy probable que esta fluida relación entre asuntos religiosos y políticos tuviera consecuencias en las empresas constructivas del monarca. Posiblemente la financiación de edificios eclesiales fue contemplada como un servicio que realizaba el monarca al santo titular o al propio Dios y que tendría una contraprestación en beneficios terrenales, muy concretamente en la ampliación del territorio cristiano a costa de los musulmanes.

El do ut des aflora en las muchas promesas que hace a los santos y sus instituciones en la expectativa de nuevas conquistas. Fue costumbre que Sancho Ramírez concediera a catedrales, canónicas y monasterios edificios en localidades todavía por conquistar, donde emplazar iglesias que pasarían a pertenecer a la correspondiente institución eclesiástica. Con esta práctica conseguía aumentar su implicación en las campañas de conquista, desde las fases preparatorias (incluida la captación de recursos) hasta los esfuerzos bélicos finales ${ }^{205}$. La constitución de capillas reales en localidades especialmente relevantes por su valor estratégico es otra vertiente de la misma política. Las vemos en Uncastillo, Monzón, Alquézar y Loarre ${ }^{206}$. Sería conveniente valorar en qué medida la dimensión militar pudo afectar a iglesias tan alejadas de los campos de batalla como Siresa. Hemos visto que allí, en la cabecera del valle de Echo, fue establecida una capilla regia. Un documento de Alfonso I atestigua que ya desde tiempos de sus antepasados el Valle de Echo suministraba la guardia personal del soberano ${ }^{207}$. No creo desencaminado poner en relación ambas circunstancias.

Este marco de implicación conquistadora de las instituciones religiosas alumbra la edificación en paralelo de castillos e iglesias. En 1091 el soberano confía al obispo de Pamplona la construcción de la iglesia del nuevo castillo llamado Superce-

205 En 1086 promete a la catedral de Jaca la iglesia de las Santas Masas de Zaragoza (cuarenta años antes de la conquista de la ciudad a manos de su hijo Alfonso I): Sub Christi nomine et eius gratia. Ego Sancio rex et Petro Sancii filius meus, dono Deo et beato Petro Clauiculari et uobis domno Petro episcopo Iaccensis ecclesie, illam ecclesiam de Sanctas Massas cum suis pertinenciis que modo habet uel in ante, Deo miserante, habetur; et hoc facio propter remedium anime mee et parentum meorum (...) Hoc donatiuum fuit factum in illa ortariza de Zaragoza: CANellas, Colección, doc. 86. El mismo año en que promete a la Selva Mayor las mezquitas de Ejea y Pradilla para que en ellas construyera iglesias una vez que Dios se las hubiera dado: Et quando Deus pro sua pietate dederit ipsas uillas sancte christianitati utriusque uille mischitas ad ecclesias ibi faciendas Deo et Sancte Marie Maioris Silue: Canellas, Colección, doc. 91. En Ejea se construyeron dos iglesias, una dedicada al Salvador y otra a Santa María. En 1093 promete al monasterio de San Ponce de Tomeras, donde había entregado a su hijo Ramiro, capellam zude de Osca, si Deus eam mihi dederit uel filio meo (...) ecclesiam et capellaniam de Tutela, si Deus omnipotens eam mihi dederit (...) ecclesiam et capellaniam de Tortosa ciuitate, si Deus omnipotens eam mihi dederit (CANELlas, Colección, doc. 136). Y en 1093, promete a la iglesia de Jesús Nazareno en Montearagón la mezquita mayor de Huesca (que no pudo conquistar antes de su muerte) y la iglesia de Santa María de Zaragoza.

206 Canellas, Colección, docs. 98, 110 y 133.

207 Privilegio de Alfonso I a los pobladores del Valle de Echo: propter multa servicia que michi fecistis et antecessoribus meis obuietis et succurratis in meas hostes et in meos appellitos et in meas caualgatas et sempre custodiatis et defendatis corpus meum tam de nocte quam de die siue in hoste siue in caualgata, ubicumque fuerimus bene et fideliter et prudenter muniatis et custodiatis corpus meum: J.A. LEMA PuEYo, Colección diplomática de Alfonso I de Aragón y Pamplona (1104-1134), San Sebastián, 1990, doc. 112, p. 171. 
saraugusta que acababa de emprender para amenazar la capital taifa ${ }^{208}$. El monarca espera de los clérigos que se encargarían de servir a Dios, orar por las almas de los reyes y sus parientes, edificar la iglesia, honrarla y custodiarla con sus casas y torres siempre fielmente ${ }^{209}$. La edificación del castrum se inicia inmediatamente, de modo que ese mismo año se fecha la concesión de fuero a los pobladores in tertio mense hedificationis ipsius castri ${ }^{210}$. Las rentas que recibían las iglesias dotadas por los monarcas eran fuente de ingresos susceptibles de empleabilidad en la gran tarea del reino: la conquista de las tierras meridionales, en la que ciertos prelados participaban directamente, al frente de sus propias huestes.

\section{Arquitectura militar y conquista del territorio}

Hemos visto hasta qué punto fue importante la arquitectura militar en el territorio aragonés a lo largo de los siglos X y XI. El reinado de Sancho Ramírez continúa esta dinámica y la abundancia de fuentes escritas proporciona claves para entender un poco mejor una casuística muy variada, en la que figuran torres y castillos alzados directamente por el rey, o bien por mandato del rey, o por otros personajes o instituciones. Las fortificaciones tienen finalidad preferentemente defensiva (como la edificada por el abad Banzo de Fanlo antes de 1067, que al parecer fue decisiva para el mantenimiento de Alquézar en manos cristianas cuando las tropas andalusíes acaudilladas por Muqtadir recuperaron Barbastro ${ }^{211}$ ), ofensiva (Castellar y Montearagón) o nacen directamente vinculadas al proceso de repoblación, canalizando mediante su edificación la participación de la nobleza. Signo de poder regio o señorial, punto fuerte que domina una comarca o controla una vía de comunicación, elemento dentro de una red defensiva u ofensiva vinculada una frontera más zonal que linear ${ }^{212}$, los documentos revelan que la

208 Ego Sancius Dei gratia rex aragonensium et pampilonensium, una cum filio meo Petro, auxiliante diuina clemencia, cepi edificare castrum quod placuit uocari Super-Cesaraugustam, ad destructionem sarracenorum et dilatationem christianorum. Et elegi Petrum pampilonensem episcopum ad faciendum ibi ecclesiam in honore sancti Petri Apostolorum principis: CANEllas, Colección, doc. 125. Finalmente se encargarían de la construcción de la iglesia el obispo y el abad de Leire.

209 Canellas, Colección, doc. 125: Pro hac quidem elemosina et beneficio ego et filius meus et posteri mei pro remisione peccatorum facto, nullum expectemus tributum uel seruitium nisi seruire Deo et orare pro animabus nostris et parentum nostrorum et edificare ecclesiam et honorare eam et custodire cum domibus suis et turribus semper fideliter.

210 Canellas, Colección, doc. 127

211 Ego Sancio, prolis regis Ranimiro, uobis abbate dompno Banzo de monasterio de Fanlo, propter optimos seruicios que mihi facistis et facitis tota hora, et quare fabricastis illa turre in Alquezar ad examplamentum de christianos et malum de mauros: CANELlas, Colección, doc. 9.

$212 \mathrm{Ph}$. SÉNAC, "Frontière et reconquête dans l'Aragon du XI" siècle", Frontières et espaces pyrénéens au Moyen Age, Perpignan, 1992, p. 54. 
edificación de torres y recintos alcanza en estos años altos estándares de calidad y rapidez.

Pero así como hay indicios convergentes de una relación directa entre el cambio de consideración de la realeza a partir de 1076 y algunas construcciones religiosas, en cambio la edificación de torres y castillos parece vincularse mucho más directamente con el transcurrir de las campañas militares y, muy concretamente, los encargos más significativos con la planificación de la conquista de Huesca ${ }^{213}$. Sancho supo explotar mediante la construcción de torres las posibilidades estratégicas de determinados emplazamientos a la hora de garantizar el éxito de las grandes campañas de conquista, que el soberano emprendió moviendo uno a uno sus peones y previendo posibles respuestas del enemigo. Ejemplo muy significativo es la torre de Obano (fig. 19), en las inmediaciones de Luna, en las Cinco Villas. Aunque en ocasiones ha extrañado su ubicación, por no encontrarse

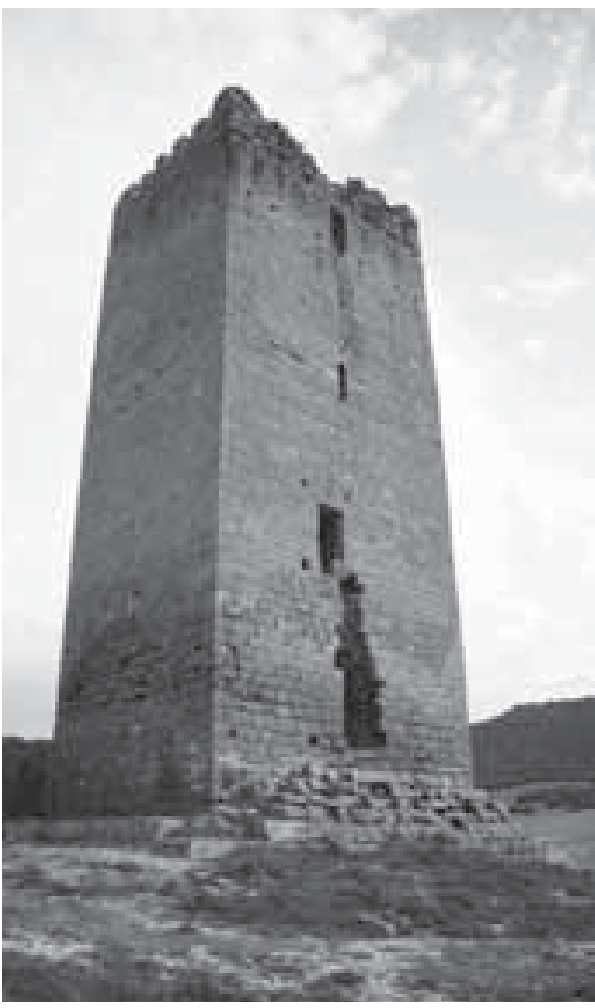

Fig. 19. Torre de Obano, cerca de Luna (Zaragona) en un alto fácilmente defendible como sucede con la mayor parte de las torres del siglo XI, existían poderosas razones para su erección con vistas a un asedio de larga duración de Huesca, porque se ubica junto al vado por el que el camino entre Ejea de los Caballeros y dicha ciudad atraviesa el río Arba. De este modo, quien controlara la torre de Obano (y Ardisa) tenía la llave del transporte de vituallas y refuerzos entre Ejea y Huesca. En un diploma de 1086, el futuro Pedro I deja entender que había sido su padre quien la había fabricado, después de haber delimitado su término (in cambium de Ripacurcia que fuit data in dote domine Felicie regine dono Uiele cum suis terminis, et Ouano cum suis terminis sicut terminabit eos rex quando incepit eum fabricare $\left.{ }^{214}\right)$.

Experiencias como la torre de Obano debieron de resultar muy útiles para un empeño de mayor ambición, el castillo de Montearagón (fig. 20), que dominaba la vía de comunicación entre Huesca y Lérida. Un documento de 1103 que recuerda

213 La torre de Biel constituye la excepción y merece un estudio detallado que valore adecuadamente sus dimensiones y complejidad, así como la abundancia de elementos residenciales. Por el momento no está claro cuál de los miembros de la familia regia aragonesa promovió su ampliación.

214 Canellas, Colección, doc. 89. 


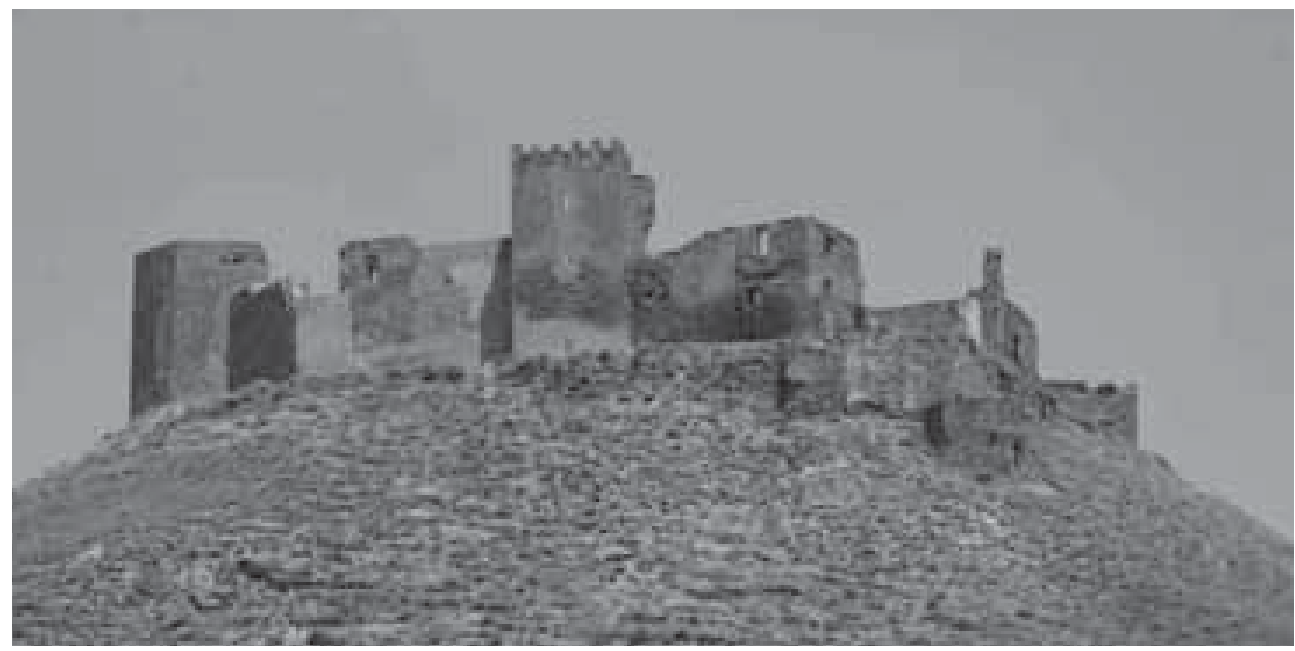

Fig. 20. Castillo de Montearagón

los orígenes del castillo expone su finalidad vinculada a la conquista de Huesca: Rex Sancius (...) contra urbem Oscam obsidendem et expugnandam, que tunc murus et clipeus tocius Ispanie in partibus illis erat, castrum Montem Aragonis nomine firmis muris et turribus stabilivit ${ }^{215}$. Inmediatamente inició la construcción de la iglesia, a tenor de la donación de $1086^{216}$. En 1087 las obras estaban en plena actividad, como acredita el diploma de donación de Artasona y en 1090 ya llevaba dos años construido ${ }^{217}$. La Crónica de San Juan de la Peña confirma la fecha de 1088 como culminación de las obras: "En el anno de Nuestro Sennyor M LXXXVIII", en el mes de mayo, el dito rey edificó el monesterio de Montearagón"²18. En 1093

215 A. DurÁn Gudiol, "El monasterio de Asán”, Homenaje a don José María Lacarra de Miguel en su jubilación del profesorado. Estudios medievales I, Zaragoza, 1977, p. 148.

216 Calore Sancti Spiritus succensi facimus donationem de rebus nostris quas nunc habemus et in proximo largiente Domino habere speramus, ecclesie quam nouiter cepimus facere in honore et nomine Ihesu Nazareni in castro quam apellamus Montearagon quod omnipotens Deus faciat nos ibi regnare per intercessionem filii sui et beate Marie et omnium sanctorum: CANELlas, Colección, doc. 85. A. Durán Gudiol, El castillo abadía de Montearagón en los siglos XII y XIII, Zaragoza, 1987, p. 12, acude al testimonio del Padre Huesca relativo a una carta de Sancho Ramírez fechada en 1085 in loco vel pueyo qui dicitur Montearagon para afirmar que en ese año se comenzó la construcción de la fortaleza. Del Arco fechaba su fundación en 1085-1086: R. DEL Arco, “El Monasterio de Montearagón”, Argensola, nº 53-54 (1963), p. 1.

217 Facta carta era M.C.XX.V $V^{a}, I I^{\circ}$ kalendas octobris, die III feria in castro hedificante et fabricante Montearagon: Canellas, Colección, doc. 97. Ego Sancius rex Ranimiri regis filius, secundo anno post constructionem castri Montis Aragonis, capto Montsone. (...) Facta carta era M.C.XX.VIII in mense aprili: CANELLAS, Colección, doc. 116. En 1093 también se dice que fue el cuarto año desde que había sido edificado: Facta est hec carta III nonas madii, era T.M.CCCI ${ }^{a}$, anno domini incarnationis T.XC.III, sub die idus ianuarii in anno IIII quo edificatus fuit et factus Montearagon: CANELLAs, Colección, doc. 137.

218 C. Orcástegui Gros, Crónica de San Juan de la Peña. (Versión aragonesa). Edición crítica, Zaragoza, 1986, p. 37. 
concede a San Ponce de Tomeras una torre con casas dentro del recinto, junto a las que poseía su hijo Pedro ante la cabecera de la iglesia, lo que prueba que al menos esa parte del templo ya estaba en pie $^{219}$.

Para estas construcciones fronterizas reservaba fondos específicos, como vimos hizo su padre en su testamento. Lo prueba la exención concedida a los habitantes de Benasque en 1087: Et retineo super uso per ad me iusticia et oste ab integra et karnale et nouena et fabricha per ad kastellos de Extremadura ${ }^{220}$.

Otro procedimiento consistía en la intervención total o parcial de nobles a quienes el monarca confiaba la edificación de una fortaleza (castrum), población cercada o torre, obteniendo a cambio el control del territorio y una parte de las exacciones impositivas $^{221}$. De este modo, la construcción constituía una inversión, un vínculo de naturaleza feudal y un punto fuerte en la articulación de la ocupación y repoblación del territorio entonces conocido como Extremadura. Los testimonios documentales de este sistema proliferan desde finales de los setenta y durante los años ochenta y noventa, cuando el soberano emprende una política activa de control del territorio fronterizo. Bastarán algunos ejemplos. En 1078 concedía a Gombaldo Ramón uno puio qui uocitant Kasterlenas ut faciatis ibi castrum et populetis eum sicut melior poteris ${ }^{222}$; en 1081 a Gombal Ermenez castrum quod uocitant Loberres ut facias in eum fortitudinem sicut unquam melis poturis, et ut fabrices eum sicut castrum conuenit fabricar [sic] et exforciare ${ }^{223}$. En 1087 los hermanos Sancho y Pepino Aznar reciben Artasona, qua est subtus terminos Aierbe, ut faciatis in eam castrum quale meliore potueritis facere et ut abeatis eum ingenuum ad uestrum proprium alodem, et quod populetis eum de populatores quos potueritis abere de ultra Alkanatis et de omines de Aragone ${ }^{224}$. En 1088 Galindo Sánchez recibe el castillo de Liscare (donamus tibi castelo Liscare quod facias eum castellum sicut melius potueris ${ }^{225}$ ), que al parecer habían fabricado los habitantes de Sos (et in istos terminos supradictos hoc quod usque hodie abuerunt laborato omines de

219 Ipsam turrim cum ipsas casas de castro quod uocatur Mons Aragonensis, iuxta casas filii mei Petri ante capud ecclesie: CANELlas, Colección, doc. 136.

220 CAnellas, Colección, doc. 95

221 J.M. LaCARra, “«Honores» et «tenencias» en Aragon (XI' siècle)”, Annales du Midi, 80 (1968), pp. 498-501.

222 Canellas, Colección, doc. 46.

223 Canellas, Colección, doc. 55. Este documento es fundamental para identificar el castillo de Loberres como distinto del de Loarre.

224 Canellas, Colección, doc. 97. En este caso la donación establece que la mitad de ciertas rentas serán para el rey: et de carneraturas et herbaticos et de zensos quos debuerint iam dicti populatores in Artasona, abeamus nos illa midietate et uso illa alia midietate cum illo castro.

225 Canellas, Colección, doc. 102. También aquí se establece la entrega de la mitad de determinadas rentas al monarca: et de populatores quod populauerint in predicto castello et de terminos quibus terminati sunt, sicut superius nominati sunt, et de herbaticos et de omicidios et de zissos, nos et omnis posteritas nostra illa medietas ad nostra proprietas, et tu illo castello cum tota illa alia medietate ad tuam propriam alodem tu et filii tui et omnis posteritas tua per secula cuncta. 
Sos abeant eum ingenuo propter quod illum castellum fecerunt sicut habuerint usque hodie); y en 1093 concede a su merino Banzo Azones en Luna un lugar donde pueda hacerse una buena torre (dono tibi in Luna ubi facias tibi una bona torre et unas bonas kasas et alode quanta poteris ibi aperire et examplare in suo termino. Similiter quoque dono tibi illa pardina que dicitur Iechar ert [sic] quod te facias ibi una bona torre et habeas eam ingenuam ad tuam propriam alodem), repartiéndose las rentas de los pobladores mitad y mitad ${ }^{226}$.

Los documentos dejan ver la existencia de otras torres edificadas por los nobles, sin que se deduzca mandato o intervención regia. En 1084 el rey dona a Lope Fortuñones la torre de Garisa, que Lope había hecho junto con Ato Sangez, con todos los términos que acababa de delimitar el rey (facio hanc cartam tibi, Lope Furtuniones, de illa turre de Garissa, quod fecistis inter te et Ato Sangeç, tu illa midietate; et ille, illa alia midietate cum totis suis terminis, sicut ego terminaui illam ${ }^{227}$ ). Una carta fechada un año más tarde, en lo que parece una interpolación, incluye la donación de la torre de Garisa por el rey a San Juan de la Peña ${ }^{228}$.

Instituciones religiosas ajenas al reino, receptoras de donaciones del monarca, participaron en el establecimiento de puntos fuertes bien defendidos ${ }^{229}$. El ejemplo más significativo se encuentra en territorio navarro. En 1084-1085 Sancho Ramírez confirmaba la donación a los canónigos de Saint Sernin de Toulouse de la antigua iglesia (ecclesiola) de San Juan de Artajona y le otorgaba varias concesiones por ser nuevamente poblada ${ }^{230}$. Veinticinco años después un diploma atestigua que los canónigos se habían encargado de la construcción de la iglesia y de las torres del recinto amurallado "desde los cimientos", con tal fortaleza que la salvó del ataque de sus enemigos ${ }^{231}$. La reciente excavación de San Saturnino de Artajona sacó a la luz vestigios de un antiguo templo de nave única y cabecera recta. El análisis químico del mortero empleado en la edificación de sus muros más antiguos ha concluido que las maderas empleadas para la preparación de la cal fueron quemadas a

226 De populatores qui ibi uenierint populare et de terminos quos ego habeo ibi terminatos et de omnibus directaticis que ibi pertinuerint habeamus per medium inter me et te, ego mea medietate ad propria mea diminicatura et tu tua medietate ad tuam propriam alodem: CANELLAS, Colección, doc. 141.

227 Salarrullana, Documentos, XXII (1084).

228 Salarrullana, Documentos, XXVII: Similiter do turrem de Garissa cum tota haereditate et pertinencia.

229 J.M. LaCARra, “«Honores» et «tenencias» en Aragon (XI' siècle)”, Annales du Midi, 80 (1968), pp. 501-502.

230 Et quoniam ecclesia ista noviter est populata, noviter est incepta et vix habet aliquid de radice, dono ei totum quod traxerit vel ruperit in termino de Artaxona: J.M. JIMENo JuRío, Documentos medievales artajoneses, Pamplona, 1968, doc. 4. También les concedió el diezmo de sus tierras en Artajona y el diezmo de la novena real que habría de destinarse a la construcción de la iglesia: ut hec decima de novena sit ad faciendam ecclesiam de Artaxona, ac post factam ecclesiam, pro redemptione anime mee: ibídem, doc. 5. La iglesia fue dedicada en 1126: ibídem, doc. 76.

231 Hanc ecclesiam nos funditus construximus cum domibus et turribus et cum maximo labore et maiore missione (...) quia nisi esset fortitudo quam nos fecimus, Artaxona fuisset destructa ab inimicis vestris et etiam a mauris: ibídem, doc. 34. 
mediados del siglo XI, por lo que la edificación de la cabecera dataría de esas fechas. No se ha procedido a estudios de esta misma naturaleza aplicados al mortero de las torres del llamado "cerco" de Artajona, pero la tipología de los cubos y los lienzos que las unen lleva a pensar que su fábrica se corresponde con lo que pudo edificarse hacia $1100^{232}$.

Una construcción rápida y de calidad era requisito para que la edificación de torres y fortificaciones se coronara con éxito, lo que debió de contribuir al progreso en la práctica constructiva con plazos limitados y circunstancias adversas. La abundancia de encargos a canteros especializados en alzar torres con celeridad debió de suponer una concentración de maestros en el área altoaragonesa que habría repercutido en la arquitectura religiosa.

$$
* * *
$$

En resumen, la afirmación de la personalidad política de una monarquía que había alcanzado total autonomía en 1076, la expansión territorial frente a los andalusíes y la religiosidad personal de Sancho Ramírez guiaron la promoción de construcciones de notable interés, en las que ciertas intencionalidades se vieron reflejadas tanto en formas arquitectónicas como en mensajes figurativos. Sus empresas constructivas manifestaron una ambición creativa y una complejidad formal y significativa muy superiores a las de sus antecesores al frente del poder en la vertiente sur del Pirineo. El movimiento iniciado por el soberano mediante obras singulares -que todavía no conocemos con la suficiente profundidad- pronto provocaría secuelas a todos los niveles. Abadías y canónicas dieron paso a prioratos y parroquias, los encargos auspiciados por los reyes fueron seguidos por otros miembros de su familia y por destacados barones de la nobleza, y los artistas de la primera generación del Románico Pleno abrieron camino a arquitectos y escultores que durante los reinados de Pedro I (1094-1104) y Alfonso I (1104-1134), hijos ambos de Sancho Ramírez, mantuvieron la vitalidad creativa del foco aragonés.

232 J. SeSMA y otros, "La intervención arqueológica" y J. MARTínez de AguiRre, "El edificio gótico y su ornamentación”, en VV.AA., San Saturnino de Artajona, Pamplona, 2007, pp. 12-58 y 76-147. 